\title{
Quality of Life on the Colorado Plateau: A Report to Camera-Survey Collaborators in Southeast Utah
}

Open File Report 01-478

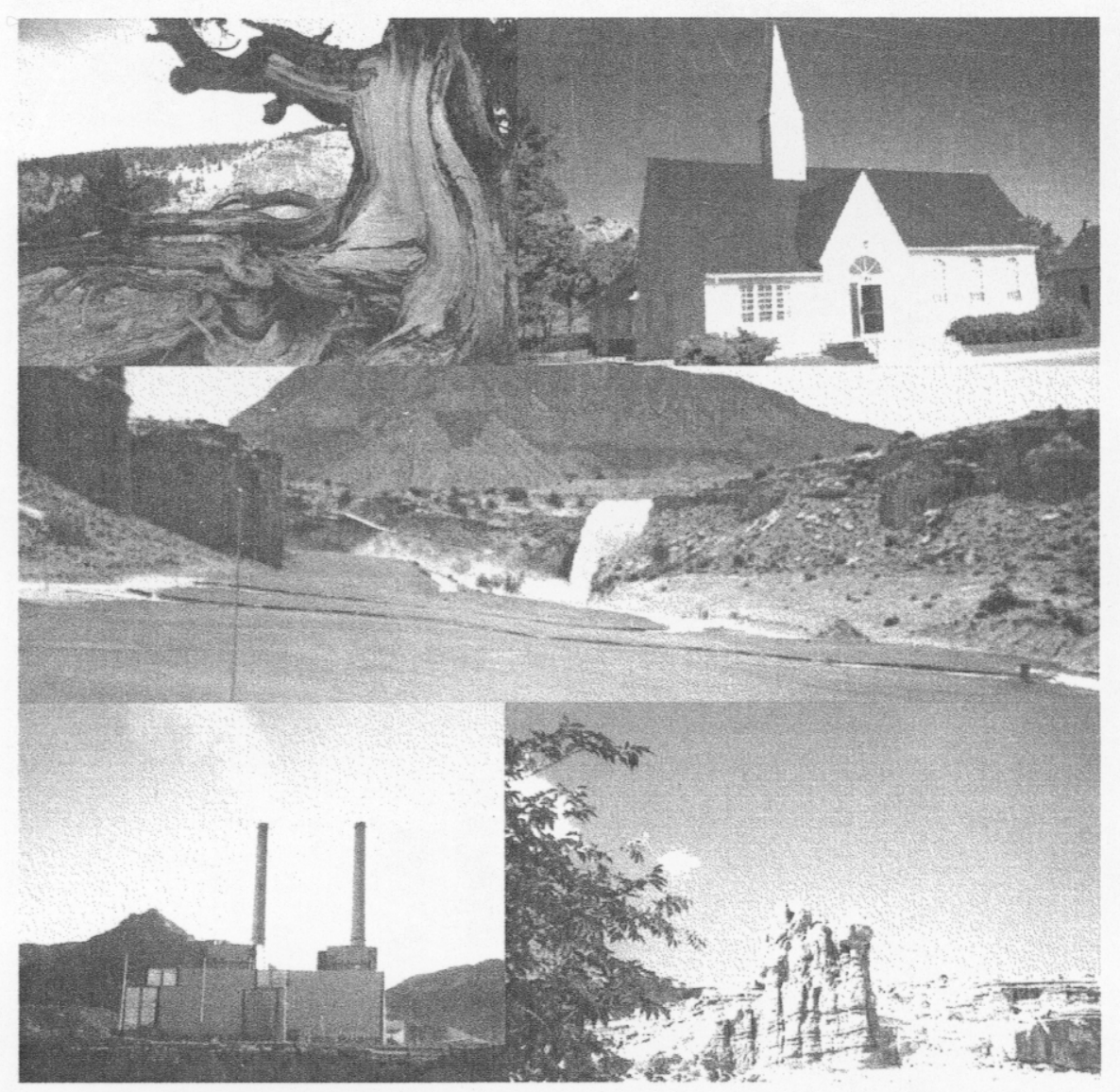

U.S. Department of the Interior

U.S. Geological Survey

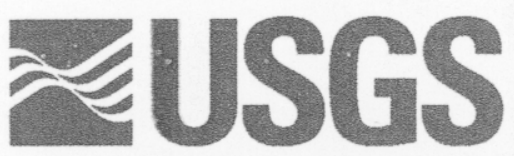

science for a changing world 


\title{
U.S. DEPARTMENT OF THE INTERIOR
}

U.S. GEOLOGICAL SURVEY

\section{Quality of Life on the Colorado Plateau: A Report to Camera-Survey Collaborators in Southeast Utah}

\author{
by \\ Jonathan G. Taylor ${ }^{1}$ \\ Jessica B. Reis-Ruehrwein ${ }^{2}$ \\ Natalie R. Sexton ${ }^{1}$ \\ Dale J. Blahna ${ }^{2}$
}

Open-File Report 01-478

This report is preliminary and has not been reviewed for conformity with U.S. Geological Survoy editorial standards. Any use of trade product, or firm names is for descriptive purposes only and does not imply endorsement by the U.S. Government. This report was previounly distributed to collabordon in April 1999. This report is available online (in PDF format) at http//www.mosc.usgs.gov/producte/presentationa/rep/rop.shtml.

${ }^{1}$ Midcontinent Ecological Science Center

2 Utah State University 


\section{Contents}

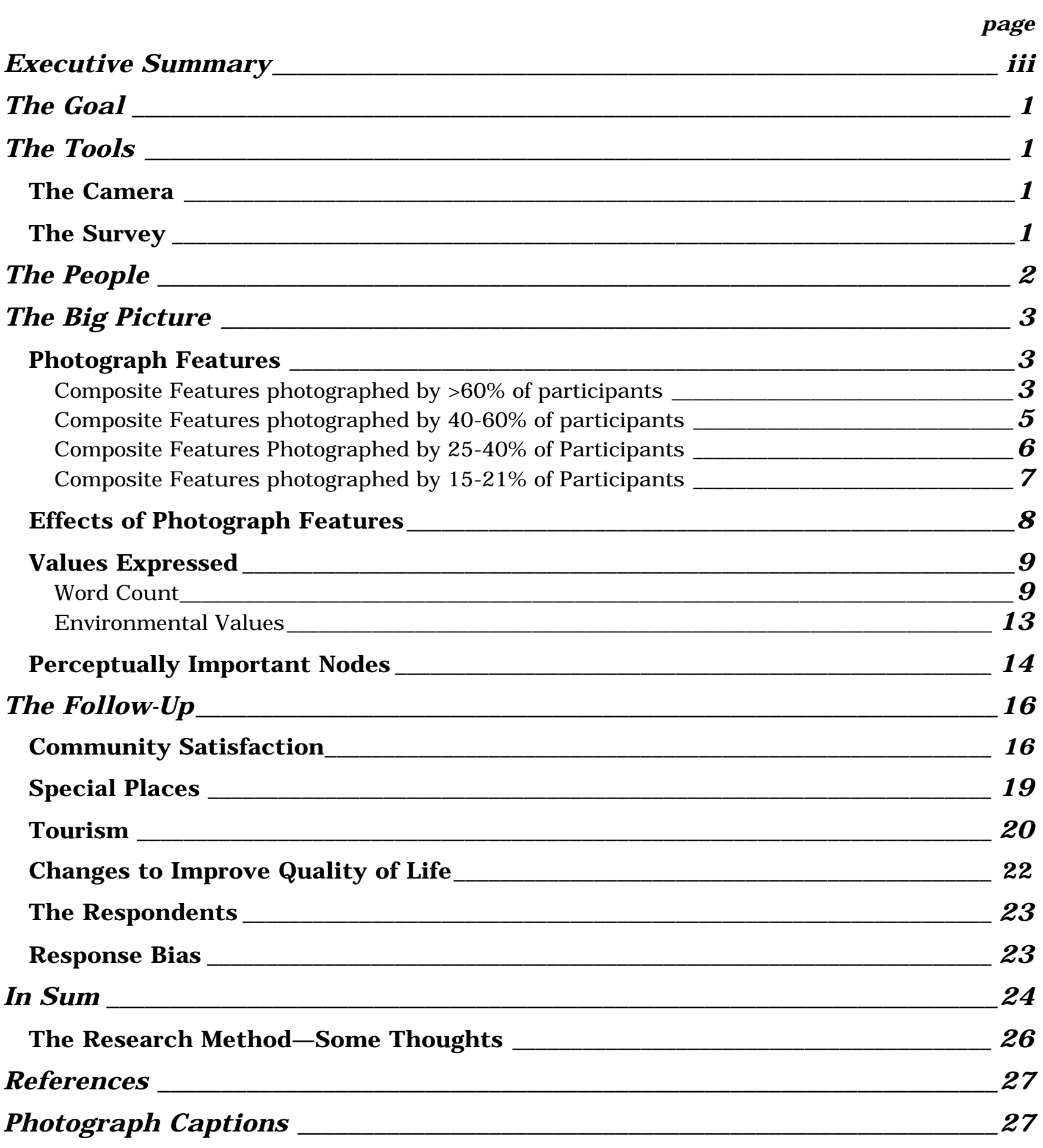

Appendix A - Photo Log

Appendix B - Follow-up Survey

Appendix C - Quality-of-life Data from the Camera Exercise

Appendix D - Quality-of-life Data from the Follow-Up Survey 


\section{Quality of Life on the Colorado Plateau}

\section{Executive Summary}

One of the most difficult issues for planners and natural resource managers is trying to determine how their decisions will affect local residents, especially the residents' lifestyles. A frequent admonition to federal, state, and local land and resource managers is, "We know things are changing, but don't ruin our quality of life." To provide some tangible evidence of what local residents mean by this expression, we administered a "ResidentEmployed Photography" survey. This involved giving 12-exposure, single-use cameras to residents of Carbon, Emery, Grand, San Juan, and Wayne counties in Southeast Utah, and asking them to show us what places and features of their communities and surrounding landscapes were essential to their quality of life. That exercise was followed up with a short mail-back questionnaire.

Two-thirds of the respondents took pictures of 'community aesthetics,' which included positive elements such as homes, subdivisions, yards and gardens as well as negative attributes such as junk cars, trash, run-down property, and some developments. Over 60\% took pictures of 'landscape vistas,' specifically mountains, canyons and valleys, cliffs, and red-rock formations. Landscape vistas were the most often photographed positive qualityof-life elements. Nearly two-thirds of the participants in this camera exercise took photos of 'public buildings and facilities,' in particular schools and libraries.

Other important quality-of-life elements that were identified in this research were open places of business; public parks and open space; cultural facilities such as museums; water bodies; streets; farms and ranches; outdoor recreation areas and activities; churches; and the people of this region. Fifty seven percent of all the quality-of-life photo-

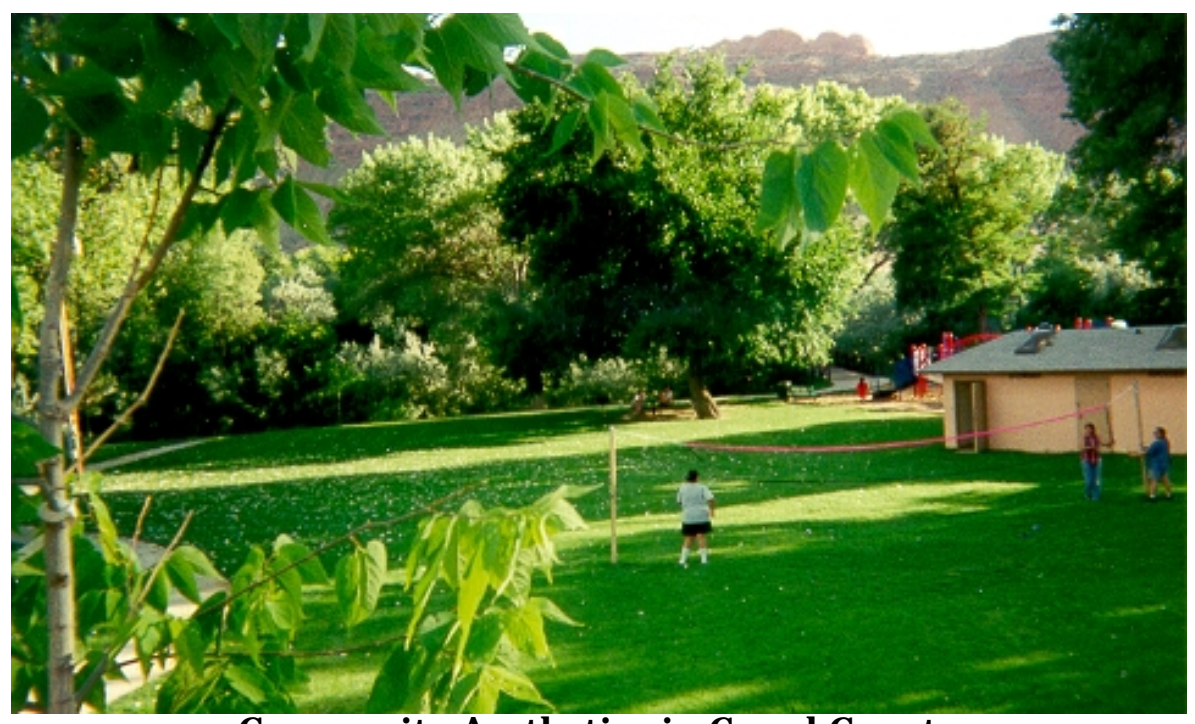

Community Aesthetics in Grand County 
graphs were taken in the communities and $43 \%$ in the surrounding landscape; nearly three-quarters were of positive elements and less than $20 \%$ were focused singly on elements negatively affecting quality of life.

Values expressed in relating why these features or places were important to quality of life were diverse. The most predominant value $(150,19 \%$ of all statements) was anything to do with 'children:' safe for children, good schools for children, children growing up with nature, ...with church values. Second among the stated quality-of-life values was beauty (12\%): $70 \%$ of which concerned the landscape or countryside and $30 \%$ the community. 'Education and learning' (11\%), frequently related to children, was third among values expressed; followed by the value of 'family' (10\%)--living and recreating together, and family connections nearby and across generations.

Other important values expressed included the rural character of the region (10\%), sense of community or neighborhood (7\%), religious values $(7 \%)$, love $(6 \%)$, friends \& neighbors (6\%), peace \& quiet (5\%), nature, and safety. Values associated with the environment (mountains, desert, canyons, etc.) were aesthetics (30\% of these countryside photos), recreational (24\%), natural (20\%), social (11\%), and 5\% each for commercial, historical, and negative values.

Perceptually important areas [PINs, Perceptually Important Nodes] were defined as elements or locations that were selected by $10 \%$ or more of each county sample. PINs, simply put, are those elements that several persons photographed, showing broader preferences. PINs for this study area include 10 city parks, 8 lakes and reservoirs, 7 mountains or mountain ranges, 7 schools and colleges, 5 museums, 4 community pools, 4 health facilities, 4 National Parks, canyons, and cultural sites, golf courses, churches, libraries, ball fields, junk yards, and others. Locations of these specific PINs are being entered into a geographic information system [GIS] so that county and municipal planners, as well as
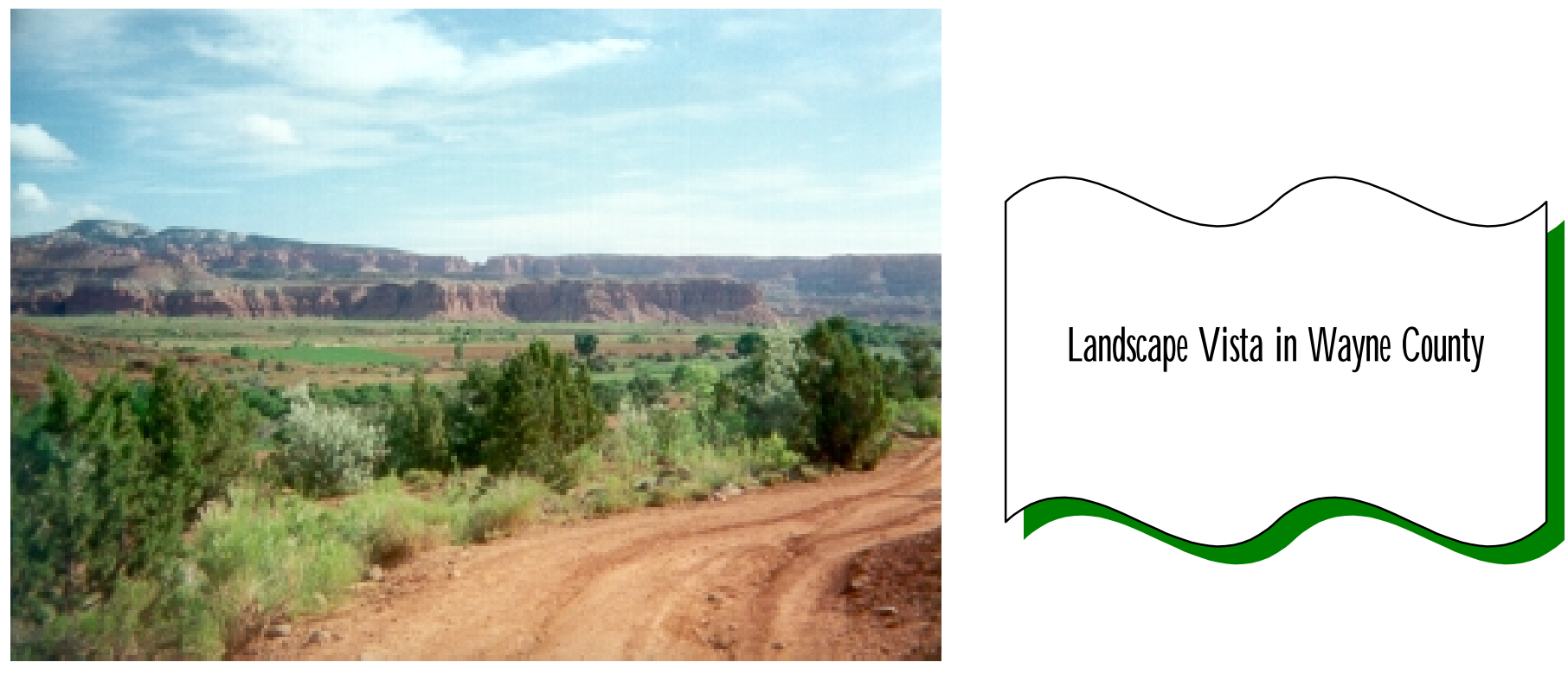
public land managers, can identify special places that local residents want to assure are protected or corrected. This location-based information will be made available via the World Wide Web to all local, regional (e.g., CCP), state, and federal agencies with land and resource management responsibilities in the region as well as to the public (visit our web site at http://www.mesc.usgs.gov/seias).

A follow-up survey was sent to each of the participants who completed the photo exercise. These surveys were completed and returned by 87 respondents, $60 \%$ of those who received them. These southeast Utah residents were quite satisfied with their communities as places to live, averaging 5.6 on a 7 -point satisfaction scale where $1=$ completely dissatisfied and $7=$ completely satisfied. What was especially good about living in their communities included the natural environment (29\%), community character (23\%), people and neighborhood qualities (23\%), plus school, work, and civic opportunities (13\%). Safety, family, and lifestyle were also stressed. When asked how important the natural environment was to their quality-of-life, respondents averaged 6.4 on the 7 -point scale, i.e. very important.

Residents were asked how important tourism was to the economic well being of their county, as well as whether they would prefer more or less tourism. Grand and Wayne Counties, who both have popular National Parks, rated tourism highest in importance among the counties, 6.0 on the same 7-point scale. Emery County rated tourism lowest, just slightly below the 4.0 mid-point. The five counties averaged 5.2 on importance of tourism scale. When asked whether they would prefer more or less tourism, again a 7point scale $(1=$ much less tourism to $7=$ much more tourism), county averages ranged from 4.0 (Neutral - Grand County) to 5.0 (increase slightly - Carbon County). The overall average on this item was 4.5 , just slightly above the "no change" point.

Respondents rated a series of 12 potential changes that could affect their quality of life. The scale ranged from $1=$ greatly decrease to improve quality of life to $7=$ greatly increase to improve quality of life. Increases were preferred for traditional jobs (5.3), attracting tourism (5.1), tourism jobs (5.0), mining (4.9), agricultural zoning (4.8), parks \& open space (4.7), and levels of tourism and outdoor recreation (4.7). Only one item was rated as needing to decrease to improve quality of life, "the amount wilderness area in Southeastern Utah” (3.2)--especially in Emery (2.2) and San Juan (2.4) counties.

The profile of a typical respondent to the follow-up survey was Caucasian (83\%), between the ages 36 and 75 (70\%), female (58\%), and having had at least some college education (71\%). Most (69\%) had household incomes between $\$ 10,000$ and $\$ 50,000$. A phone crosscheck with non-respondents to the photo-exercise, found that older residents (over 65) were more likely to have completed the photo and survey exercises than were younger residents (45 and under). Household income was about \$10,000 lower among respondents than non-respondents. This suggests that retired persons disproportionately participated in the quality-of-life survey. Some $35 \%$ of the follow-up survey respondents reported being 
retired, quite high in comparison to retired social security payment rates in the region (8\%) reported by the Bureau of Census 1996 report. These results show that the camera and survey results are not strictly representative of the full five-county population.

Nevertheless, this research has identified, from 1550 photographs, several types of community and landscape elements that need protection or correction to preserve or enhance quality of life for local residents of Southeast Utah--including 84 specific important places [PINs].

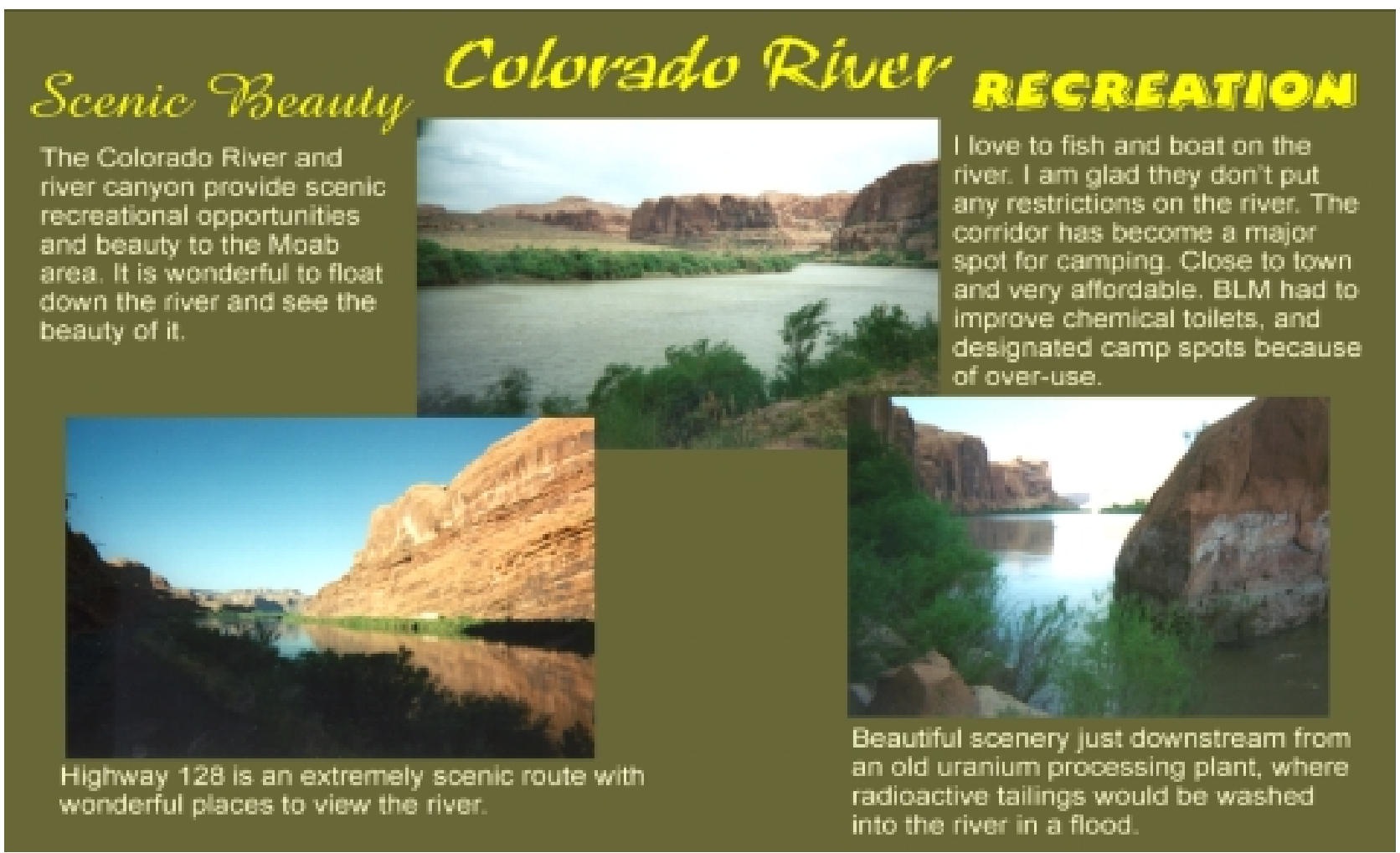

Colorado River PIN 


\section{Quality of Life on the Colorado Plateau}

\section{The Goal}

What constitutes quality of life among community residents in southeastern and central Utah? What critical areas, elements, and special outdoor places are essential to quality of life in those areas? Answering these questions was the goal of this "quality-of-life" research collaboration in the Colorado Plateau region. Collaborators include the Utah Travel Council (UTC), Canyon Country Partnership, Utah State University, and the county governments of Carbon, Emery, Grand, San Juan, and Wayne counties.

In recent years, the goal of the UTC has changed from simply encouraging tourism development to understanding the relationship between tourism and community quality of life. Elements of the new UTC mission include: "make Utah a better place to live by increasing the economic contribution of tourism," and "protect base resources and maintain quality of life for residents and visitors alike" (Utah Division of Travel Development, 1997). The Social, Economic, and Institutional Analysis Section [SEIAS]/ Midcontinent Ecological Science Center/U.S. Geological Survey conducted this research in late spring through winter of 1997 in an effort to answer those questions posed by the collaboration. This report provides an overview of the research and presents summary results.

\section{The Tools}

Two fundamental research tools were used to collect information from residents about their quality of life: (1) a 35-mm camera and photo-log booklet, and (2) a follow-up survey.

\section{The Camera}

All residents who participated were given single-use, 12-exposure, 35-mm cameras. They were asked to photograph those features, places, or activities of their community and the surrounding county that most affect their quality of life. For each photograph, participants were asked to record in a photo-log booklet: (1) what was pictured, (2) where the photograph subject was located, (3) whether the effect on their quality of life was positive or negative, and (4) their reason for selecting that particular subject (see Appendix A).

\section{The Survey}

A complete set of their photos and a follow-up survey were sent to respondents who completed the camera exercise. The survey contained standard demographic questions (age, education, etc.) and questions delving further into aspects of quality of life, special places, and community uniqueness (see Appendix B). 


\section{The People}

Random sampling was used to select residents of Carbon, Emery, Grand, Wayne, and San Juan counties to participate in this study (see map, Figure 1). Sample communities were selected in each county, based on the county seat and surrounding community clusters. Thus, Price and Helper were sampled in Carbon County; Castle Dale, Huntington, Ferron, Clawson, and Orangeville in Emery County; Moab in Grand County; Loa, Bicknell, Torrey, Teasdale, and Lyman in Wayne County; and Monticello and Blanding in San Juan County.
A random sample of residents in these communities was selected by Survey Sampling Inc.--a private business specializing in sample selection. The person in each household aged 18 or older with the most recent birthday was the sample subject. The research team attempted to contact 500 residents-140 in Carbon county, 60 in Wayne county, and 100 each in Emery, Grand, and San Juan counties. Four hundred forty nine residents were actually contacted (Table 1). Of those, 355 (79\%) agreed to participate, and 94 (21\%) declined to take part in the study. Of the 355 residents who agreed to

Figure 1. Research Area in Southeast Utah

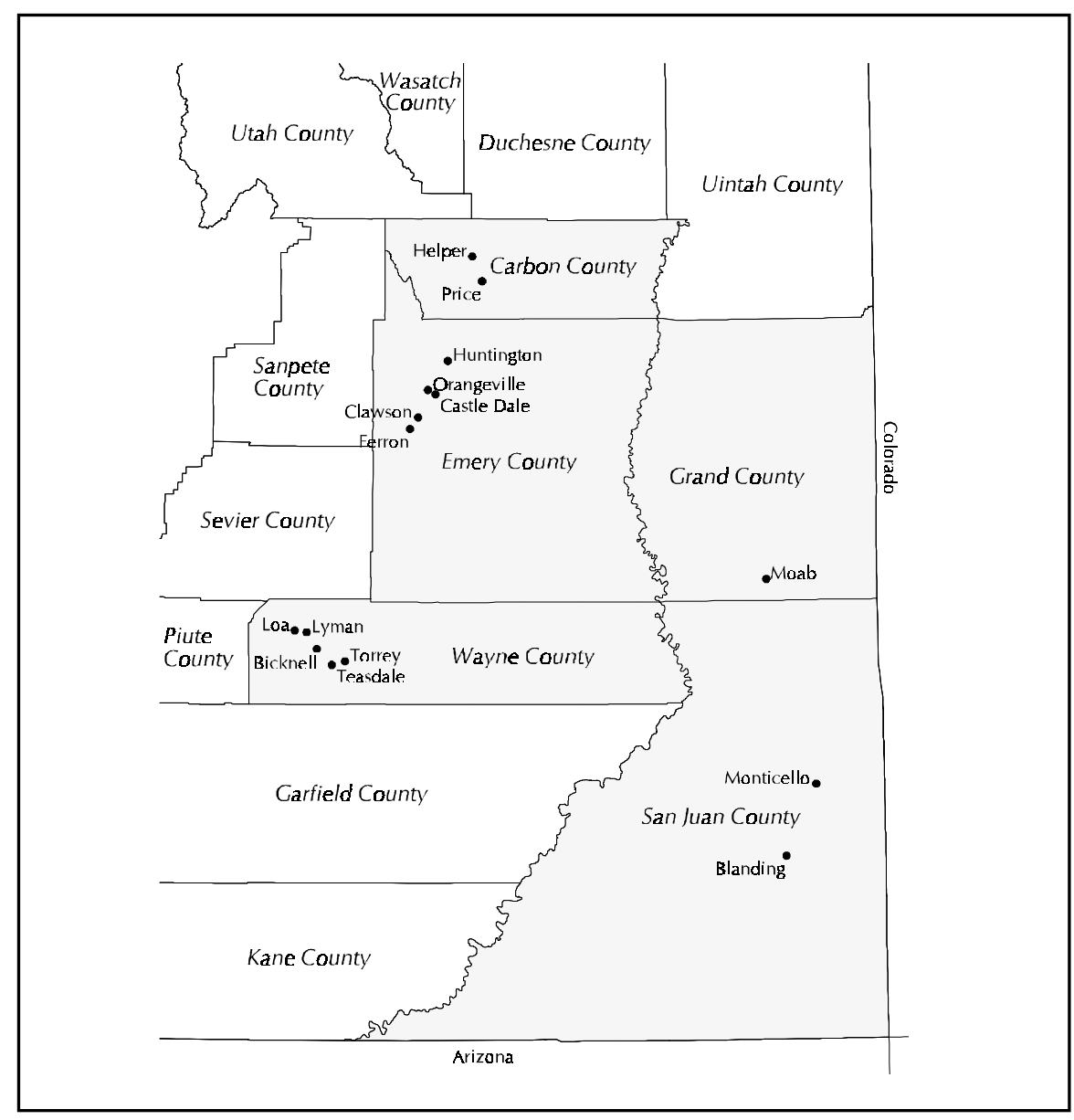


participate in the study, 144 (41\%) completed and returned the cameras and photo-logs. Eighty seven of the 144 respondents (60\%) completed and returned the follow-up survey. The response rates for the cameras and surveys were fairly evenly distributed among the counties (Table 1).

\begin{tabular}{|l|c|c|c|c|}
\hline \multicolumn{5}{|c|}{ Table 1. Camera and Follow-Up Survey Return Rates by County } \\
\hline LOCATION $^{1}$ & $\begin{array}{c}\text { Number of } \\
\text { Residents } \\
\text { Contacted }\end{array}$ & $\begin{array}{c}\text { Number } \\
\text { Agreeing to } \\
\text { Participate }\end{array}$ & $\begin{array}{c}\text { Completed Cam- } \\
\text { era } \\
\text { Exercise }\end{array}$ & $\begin{array}{c}\text { Completed Fol- } \\
\text { low-Up Survey }\end{array}$ \\
\hline Carbon County & 118 & 83 & $34(41.0 \%)$ & $20(58.8 \%)$ \\
\hline Emery County & 95 & 78 & $30(38.5 \%)$ & $16(53.3 \%)$ \\
\hline Grand County & 87 & 74 & $31(41.9 \%)$ & $21(67.7 \%)$ \\
\hline San Juan County & 88 & 70 & $30(42.9 \%)$ & $19(63.3 \%)$ \\
\hline Wayne County & 61 & 50 & $19(38.0 \%)$ & $11(57.8 \%)$ \\
\hline TOTAL & 449 & 355 & $144(40.6 \%)$ & $87(60.4 \%)$ \\
\hline
\end{tabular}

${ }^{1}$ Variables listed by counties in which sample communities are located -- Carbon County: Helper, Price / Emery County: Castledale, Huntington, Ferron, Clawson, Orangeville / Grand County: Moab / San Juan County: Monticello, Blanding / Wayne County: Bicknell, Torrey, Teasdale, Loa, Lyman

\section{The Big Picture}

Four important pieces of quality-of-life information were gleaned from the camera and survey exercise: (1) features or subjects photographed, (2) whether those features were positive or negative; (3) the values people hold in relation to the photo subjects; and (4) PINs (Perceptually Important Nodes): specific elements or places photographed by several (10\% or more) county respondents.

\section{Photograph Features}

From the photo-logs, we are able to know just what respondents were photographing (or intending to photograph). In analyzing this information, we developed a list of 124 features that included all of the subjects listed by the respondents and then aggregated those into 25 composite features (e.g., 'public buildings' is a composite feature that includes 'schools and libraries,' 'municipal buildings,' and 'health and safety facilities'). Because one respondent can take more than one picture of a feature, it is important to look at both the number of respondents who photographed a particular feature and the number of photographs taken of a particular feature. The discussion of results below, presents both of these measures.

\section{Composite Features photographed by $>60 \%$ of participants}

These first composite features were each photographed by more than $60 \%$ of respondents and represent over $10 \%$ of all photographs. Details of photo-feature distribution are presented in Table 2. 'Community aesthetics' was the composite feature photographed most often; almost two-thirds of respondents (65\%) took a total of 195 photographs (13\% of all photos taken) of these subjects (Table 
Table 2. Quality-of-Life Photo Subjects: Photographed by $60 \%$ or More Respondents

\section{Community Aesthetics 93 people took 195 photographs}

$\begin{array}{lll}\text { Homes } & 78 \text { photos } & \text { (46 positive, 24 negative) } \\ \text { Projects/Trailer Parks/Subdivisions } & 36 \text { photos } & \text { (22 positive, 10 negative) } \\ \text { Yards and Gardens } & 32 \text { photos } & \text { (19 positive, } 7 \text { negative) } \\ \text { Flowers and Trees in town } & 19 \text { photos } & \text { (10 positive, } 3 \text { negative) } \\ \text { Neighborhoods } & 12 \text { photos } & \text { (8 positive, } 3 \text { negative) }\end{array}$

\section{Landscape Vistas}

Mountains \& Hills

Valleys / Canyons

Cliffs, Rock formations

The Desert environment

Atmosphere, air quality

III. Public Buildings

Schools and Libraries

Municipal / County buildings

Health \& Safety
89 people took 187 photographs
72 photos
30 photos
30 photos
24 photos
21 photos

93 people took 185 photographs

102 photos

44 photos

38 photos
(54 positive, 10 negative)

(23 positive, 5 negative)

(19 positive, 3 negative)

(16 positive, 3 negative)

(16 positive, 12 negative)

2). 'Homes' were the specific feature photographed most often within this composite feature, followed by 'Projects/subdivisions' and 'yards and gardens.'

The second-most photographed aggregate features were 'landscape vistas;' 89 (62\%)

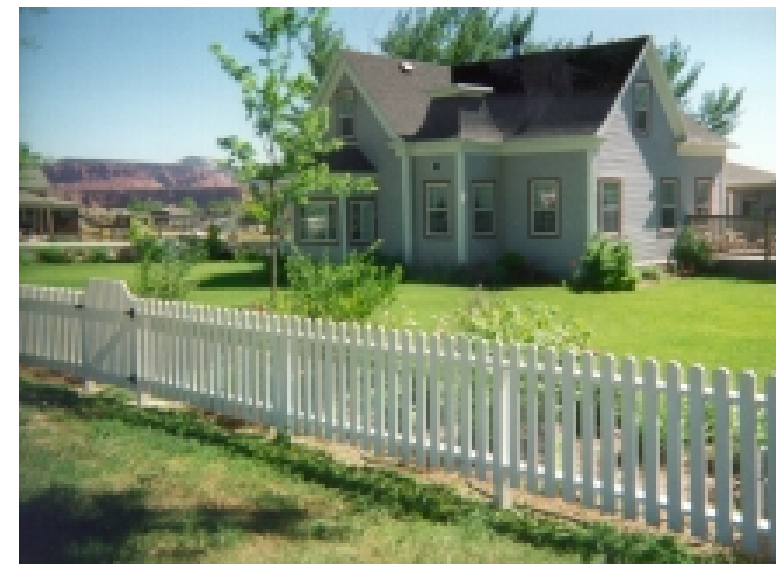

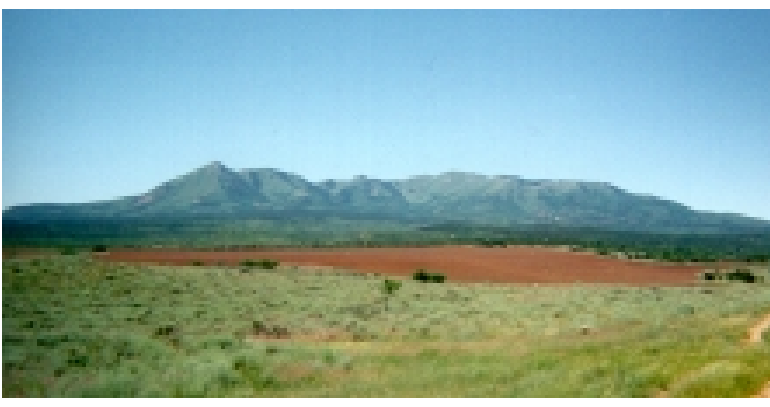

respondents took 187 photos (12\%) of this composite feature. The specific features, 'mountains,' 'canyons and valleys,' 'cliffs and formations,' and 'desert and red rocks' made up over $80 \%$ of this aggregate feature. 'Public buildings and facilities' (185 photographs; 12\%) tied for the highest number of respondents photographing an aggregate feature (93 respondents; 65\%). 'Schools and libraries,' 'municipal buildings' and 'health and 
safety facilities' make up this entire composite feature.

\section{Composite Features Photographed by 40- $60 \%$ of Participants}

The next composite features each account for $6-8 \%$ of all photos taken, by 40 $53 \%$ of the respondents: 'Open businesses,' 'town parks and open spaces,' 'cultural sites or buildings,' and 'water bodies' (Table 3). 'Viable Businesses' were important to southeast Utahan's quality of life; 76 people (53\%) took 120 photos $(8 \%)$ of these subjects. A variety of businesses make up this composite feature, including 'shopping centers,' 'motels,' and 'other businesses' such as banks, auto shops, and beauty salons.

Sixty-nine people (48\%) took 112 photos (7\%) of 'town parks and open spaces.' Most important among these were 'city parks,' 'ball fields' and 'golf courses.' 'Cultural sites or buildings' were photographed 91 times $(6 \%)$ by 60 people (42\%). 'Museums' make up the largest specific feature of this group, followed by 'historic sites' ( buildings, trails, and historic parks) and 'archaeological sites' (ruins and rock art).

We have found that 'water bodies,' depending upon their availability or accessibility, are almost always an important

Table 3. Quality-of-Life Photo Subjects: Photographed by 40-60\% of Respondents.

IV. Businesses - open

Shopping / Stores

Other stores

Motels, B \& B's

V. City Parks \& Open space

City parks

Ball parks

Golf Courses

City Parkways \& walks

VI. Cultural Facilities

Museums

Historic Buildings

Pioneer Trails \& Parks

Rock art \& Ruins

VII. Water bodies

Lakes \& Reservoirs

Rivers, streams, falls
76 people took 120 photographs

$\begin{array}{ll}35 \text { photos } & \text { (25 positive, } 5 \text { negative) } \\ 46 \text { photos } & \text { (35 positive, } 9 \text { negative) } \\ 15 \text { photos } & \text { (11 positive, } 3 \text { negative) }\end{array}$

69 people took 112 photographs

39 photos

(31 positive, 7 negative)

25 photos

(18 positive, 4 negative)

23 photos

(18 positive, 5 negative)

16 photos

(9 positive, 5 negative)

60 people took 91 photographs

32 photos

(26 positive, 2 negative)

11 photos

(9 positive, 1 negative)

11 photos

(8 positive, 1 negative)

10 photos

(7 positive, 2 negative)

68 people took 90 photographs

56 photos

(42 positive, 9 negative)

26 photos

(18 positive, 6 negative) 

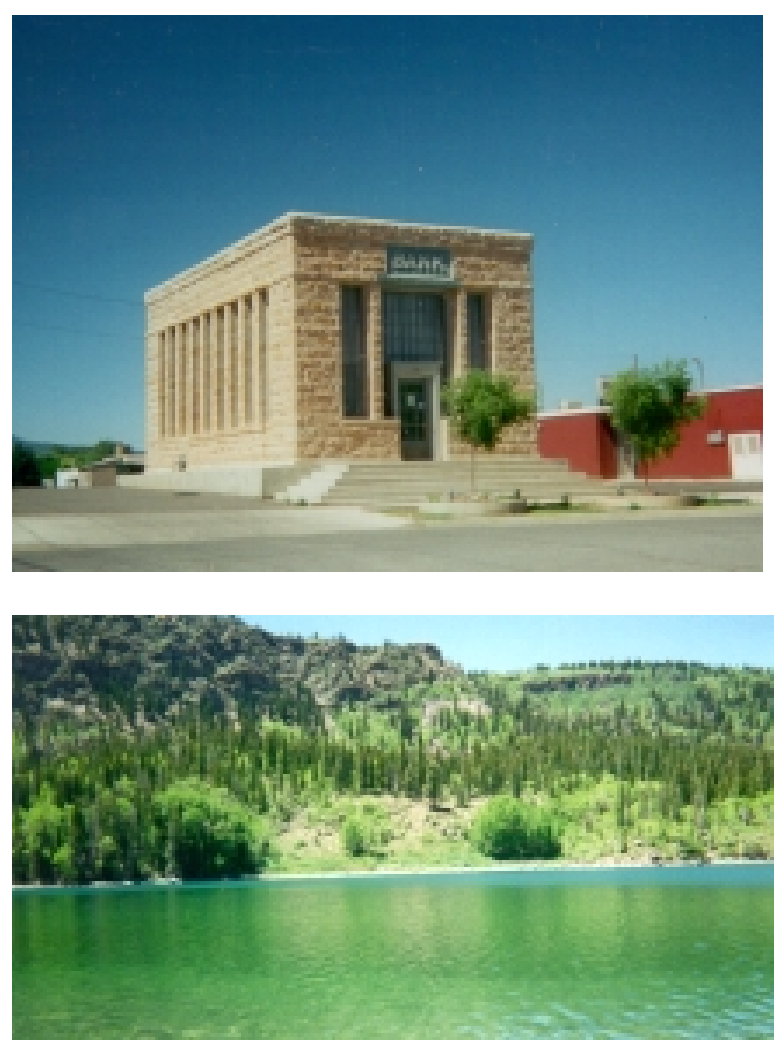

part of people's perception of landscape (Shafer, 1969; Taylor et al. (1996). In this study, 68 respondents (47\%) took 90 photographs $(6 \%)$ of water bodies. 'Lakes and reservoirs' and 'rivers, streams, and falls' make up the bulk of this composite feature.

\section{Composite Features Photographed by 25- 40\% of Participants}

The next set of composite, quality-of-life features--'streets and traffic,' 'agriculture and ranching,' 'rural recreation,' 'in-town recreation,' and 'churches'--each account for $3-5 \%$ of the total photographs and were photographed by roughly $1 / 4$ to $1 / 3$ of the respondents (Table 4). First among these were 'streets and traffic'--53 people (37\% of the sample) took 83 photographs (5\% of all photos). Specifically, 'wide streets,' followed by 'construction and re-
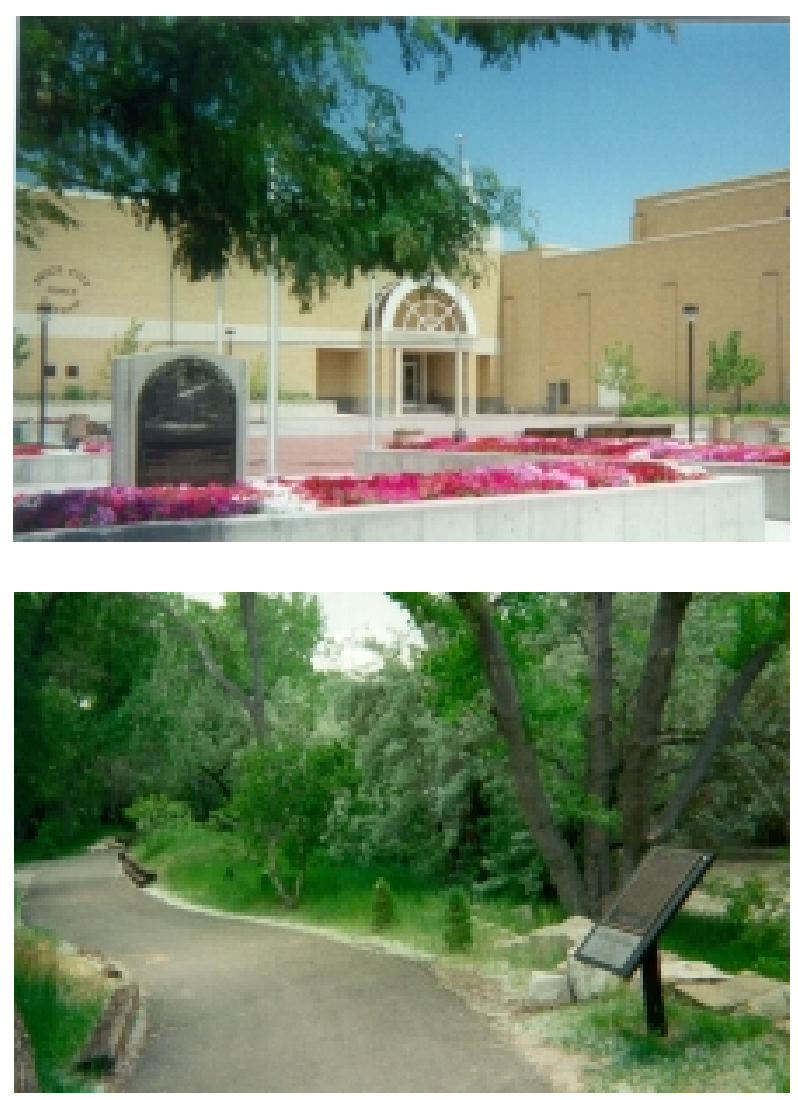

pair,' and 'traffic' were the most frequently photographed of these features. Next in number of photographs taken was 'agriculture and ranching' (70 photographs; 5\%), but this composite feature was photographed by only 35 people (24\%), fewer than for 'rural recreation,' 'churches' or 'in-town recreation' (see below). Respondents, who live on farms or ranches, preferred to take several of their photographs in rural, agricultural settings. Thirty eight people (26\%) took 55 photographs (4\%) of 'rural recreation.' Twenty-six of these photographs were of 'campgrounds' and 'state parks;' only six were identified as 'National Park' or 'National Forest.' In comparison, nearly the same number of respondents (37; 26\%) took photographs of 'in-town recreation' (46 photographs; 3\%), nearly half being of 


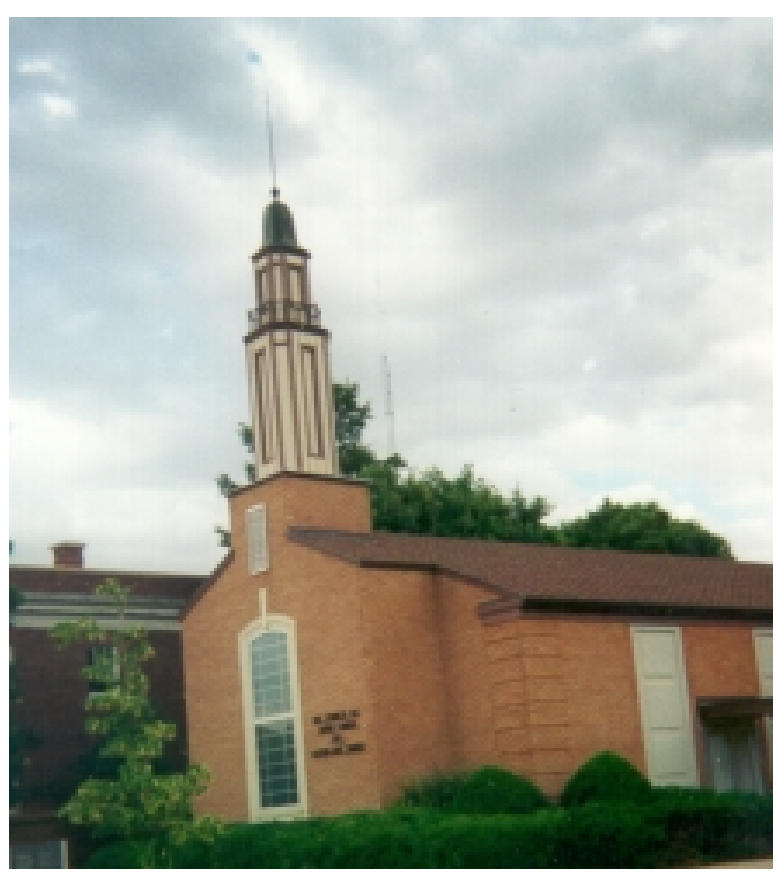

'municipal swimming pools.'

Churches are important to residents' quality of life in southeastern Utah. Forty three people (30\%) took 49 photographs $(3 \%)$ of churches. These respondents tended to stress the importance of their church in their written responses, but generally took only one photo of the church--as opposed to agriculture, for example, where the average was two photos per individual.

\section{Composite Features photographed by 15-} 21\% of Participants

The set of composite features 'people,' 'industries,' and 'animals in town' were photographed by $15-20 \%$ of the respondents, accounting for $2-3 \%$ of all qualityof-life photographs taken (Table 5).

Thirty people (21\%) took 48 photos (3\%) of 'people:' 'family and children' and 'friends and neighbors.' 'Industries' in the
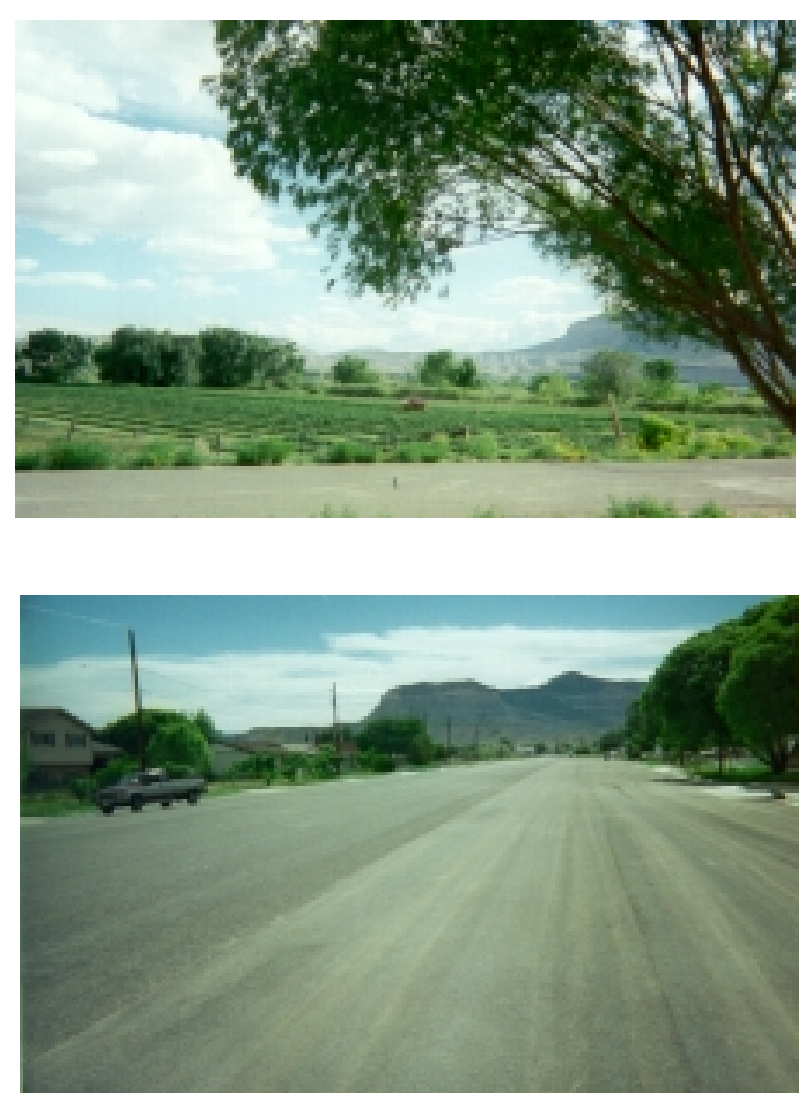

countryside were photographed by 28 people (19\%), accounting for $2 \%$ of the photographs taken (35 photographs) . These photographs, generally, were either of 'power plants' or 'coal mines and processing facilities.' Finally, 'animals in town' were categorized separately, with 30 photographs (2\%) taken by 21 people (15\%). 'Livestock,' especially horses, made up the majority of this category, followed by 'pets.'

The quality-of-life features described above and in Tables 2-5 account for 90\% of all the photographs taken. The additional composite features were each photographed by fewer than $15 \%$ of the respondents and each accounted for fewer than $2 \%$ of the total photographs. 
Table 4. Quality-of-Life Photo Subjects Photographed by 25-40\% of Respondents VIII. Streets \& Traffic $\quad 53$ people took 83 photographs

$\begin{array}{lll}\text { Wide streets \& Highways } & 20 \text { photos } & \text { (14 positive, } 5 \text { negative) } \\ \text { Construction / Repair } & 16 \text { photos } & \text { (9 positive, } 6 \text { negative) }\end{array}$

IX. Agriculture / Ranching 35 people took 70 photographs

$\begin{array}{lll}\text { Farm/Ranch - Irrigated fields } & 36 \text { photos } & \text { (30 positive, } 4 \text { negative) } \\ \text { Livestock, Horses } & 24 \text { photos } & \text { (20 positive, } 4 \text { negative) }\end{array}$

\section{Rural Recreation}

Campgrounds

State Parks

National Parks / National Forests

38 people took 55 photographs

(11 positive, 5 negative)

(7 positive, 2 negative)

(4 positive, 1 negative)]
XI. Churches

Churches

XII. In-Town Recreation

Municipal Pools
43 people took 49 photographs

49 photos

(40 positive, 5 negative)

37 people took 46 photographs

22 photos

(16 positive, 4 negative)
More detail on photo frequency by county is available in Table $\mathrm{C}-1$. The numbers per county are reported in the Appendix tables to provide individual results to each county. Due to the relatively low numbers of respondents within each county, statistical comparisons of county results are not valid.

\section{Effects of Photograph Features}

Respondents were asked to record, in the photo-logs, whether the effect each feature photographed had on their quality of life was positive or negative. Details of the positive vs. negative photo-results can be found in Tables 2 through 5 and C-2.

Table 5. Quality-of-Life Photo Subjects Photographed by 15-21\% of Respondents.

XIII. People

Family, Children
Friends \& Neighbors

XIV. Industries

Power plants

Mines \& Coal processing

XV. Animals in town

Livestock - especially horses

Pets
30 people took 48 photographs
31 photos
(23 positive, 2 negative)
10 photos
(7 positive, 2 negative)

28 people took 35 photographs

(14 positive, 3 negative)

(12 positive, 3 negative)

\section{5 photos}

21 people took 30 photographs

(14 positive, 3 negative)

(8 positive, 2 negative) 
This is an important modifier of our earlier statistics of "most photographed features." For example, although 'community aesthetics' was the most photographed quality-of-life feature (195 photos), 'landscape vistas' was the most photographed positive composite feature (164 photos; $14.3 \%$ of all positive photos taken). This was followed by 'public buildings and facilities' (156 photos; 13.6\%); 'parks and open space' (102 photos; 8.9\%); 'community aesthetics' (94 photos; 8.2\%); and 'cultural' features (88 photos; $7.7 \%$ ).

The most photographed negative composite quality-of-life feature was 'community aesthetics' (79 photos; $27.9 \%$ of all negative photos taken). This was followed by 'streets and traffic' (40 photos; 14.1\%), 'businesses, open' (34 photos; 29.3\%), 'public buildings and facilities' (21 photos; 7.4\%), and 'human impacts' such as trash or erosion (19 photos out of town and 17 in town; $6.7 \%$ and $6.4 \%$, respectively). Interestingly, 'community aesthetics,' which was among the top 5 positive photographed features, was also the most photographed negative feature.

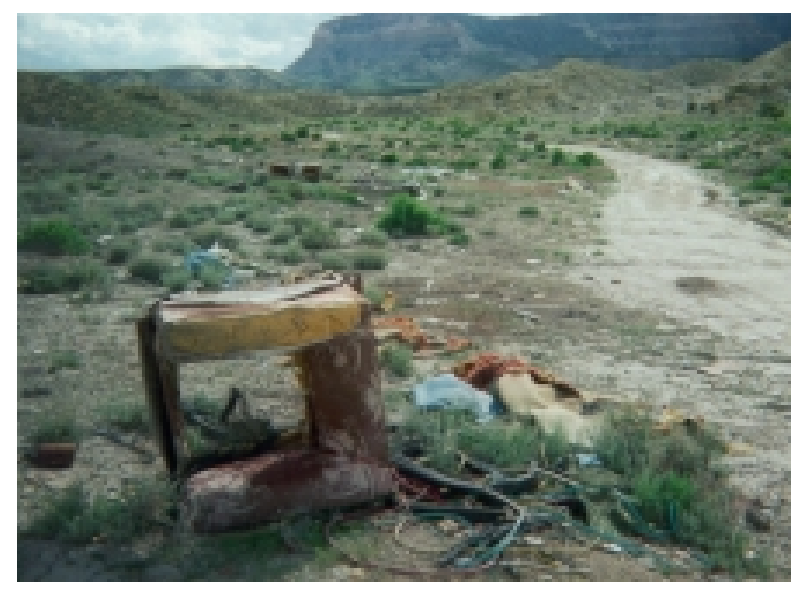

Negative 'community aesthetics' photos tended to be of junked cars and other accumulated trash, or of unkempt or rundown houses and yards. Also 'open businesses' were among the top 6 positive features and among the top 5 negative subjects. The latter most often were of fast-food chain restaurants, garish motel or store fronts, or businesses perceived as unnecessary: "We don't need this!"

There were more negative photographs taken in town (62.3\%) than out of town (37.7\%), slightly higher than the overall town to countryside photo ratio of $57.3 \%$ to $42.7 \%$. A comparison of the effect of features by town or country location, however, does not reveal any significant differences.

\section{Values Expressed}

For every photograph, participants in the camera exercise were asked to explain, "Why does this feature have an important effect on your quality of life?" Values are expressed in these statements that directly pertain to residents' quality of life. We searched for value expressions in two ways. First, we did a word count of value terms and second, we compared statements about landscape photographs with a list of value terms taken from natural resource management literature. These values are presented in this section and in Tables C-3 through C-5. The numbers in these tables represent the number of photograph explanations associated with each value term.

\section{Word Count}

Respondents statements of "why does 
this feature ... have an important effect on your quality of life?" were searched to find frequently expressed value terms. Counting the frequency of occurrence of these terms derived the first list of values. Once the list of terms was prepared, entries were validated to ensure that the meaning expressed actually fit the category. For example, a comment such as, "That black eye that was a real beauty," would not be included in a 'beauty' category. A single statement may express more than one value, for example, "good schools are important for our children" would be included in both 'for children' and 'schools / education.'

The overriding value expressed for 1 out of every10 photograph explanations (19\% of the value statements), was anything that pertained to 'children' (Table C-3). This category included values such as children's safety in the community: "We

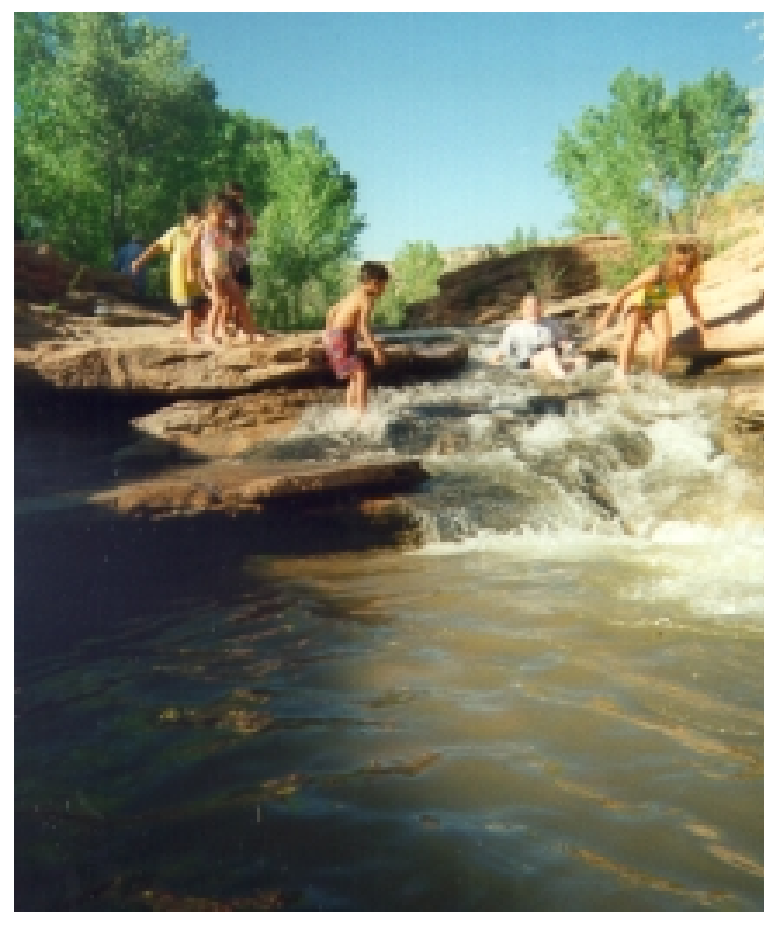

know our neighbors and can help each other. Children are growing up in a happy secure environment;" value of the out of doors and animals: "children and the outdoors, gives them the sense to appreciate nature." People pointed out that schools are good for the children and museums teach children about their heritage: "Indian pictographs, this area has a lot of history and I can share that with my children and teach them to respect it." Also, higher education and companies that hire young people, and thus help "keep children in the community" as they mature, were highly valued: "The college is growing, more young people are getting an education without having to move away."

Beauty' was a very strongly expressed value in southeast Utah, contributing very importantly to quality of life in this region (13\% of all value statements). Almost three fourths of these 'beauty' statements concerned countryside, landscape subjects: "This is beautiful, peaceful country, some of us have spent our whole life here loving and taking good care of it." In-town beauty included statements such as: "A beautiful little museum covering much of the history of

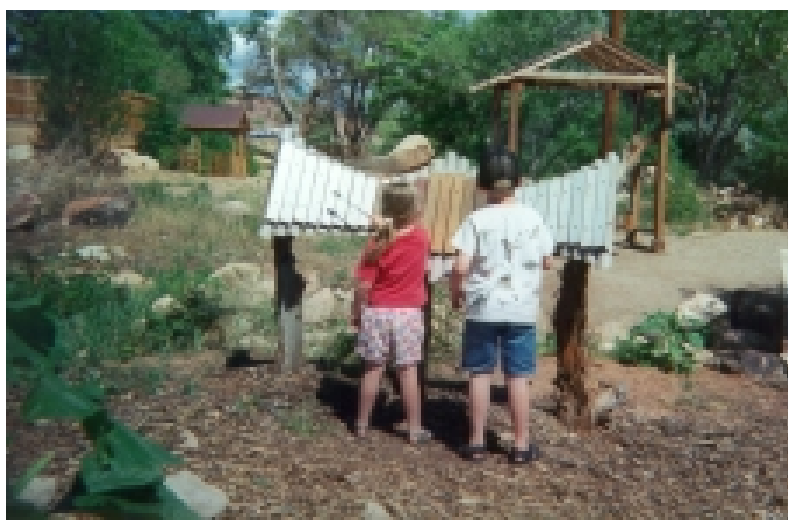


the area." Only 5\% of 'beauty' statements were negative comments (e.g., trashy locations detracting from 'beauty') and all of those were in-town photos.

'Education and learning' constituted the third most expressed value (11\%) in this survey, overlapping with the value of children. Respondents stated this value in several different ways: "one of our first priorities is good schools for our children," "Schools make a community, without them we are lost." Educational values were not exclusively for children, although more than half clearly focused on young people's learning. Community colleges were valued for being able to help people improve their lives through continuing education, as well as for keeping young adults in the community as they prepare themselves for the world: "Education of young adults . . contributes to everyone's future."

The fourth most stated value was 'family' (10\%), also closely related to children. This is not the political expression of "family values," but the specific values of doing things as a family, living together as a family, and having family connections that pervade these communities

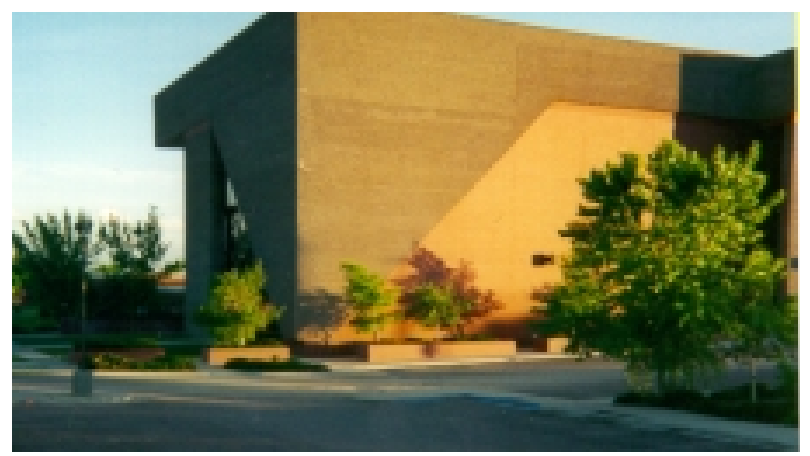

across space and time. "SE Utah is very family oriented. My children have grown up with both sets of grandparents living within ten miles." "When my family was growing up they spent many hours with each other hiking and enjoying nature;" "Good place to raise a family, good values taught here."

The fifth most frequently stated value referred to agriculture, ranching, and the open 'rural character' of the area (10\%). "We enjoy the quality of life provided by ranching, [where] life might be sustained and enhanced with beauty and joy." "Looking into farmlands is a serene pastoral setting, a relaxed lifestyle." Those most strongly grounded in agriculture underscored this relationship with statements such as, "This is our life."

The value term of having a "sense of community" occurred 37 times. "I have felt a sense of community many times" here, "This is a close knit community," with a "sense of history in the community." The term 'neighborhood' was used 21 times in a very similar way, showing a sense of a united living area where people know and interact with one another. "It is a good quiet neighborhood," "this is an integrated neighborhood where people care." These categories combined produced 58 hits (7\%), and ranks them sixth among quality-of-life value terms (Table C-3).

People also used 'community' as a setting rather than a value, e.g., "water is essential to our community," and "many people in this community grow flowers." The fact 
that 90 respondents referred to their home as their 'community' is also important. There are many places in the United States where the term would be used far less consistently.

In Utah, with such a strong religious heritage, 'religious values' were strongly stated in residents' quality of life: (53 times, 7\%), ranking seventh. County planners, across the southeastern Canyon Country region of Utah describe two patterns of development related to religious values. In traditionally agricultural and ranching communities there is a predominance of Mormonism and our results show much of the religious value there focused on homogeneity: "I enjoy living in a community where religion is important and where many of my neighbors are of the same faith. Many of the community and family values originate with this common religion." In the traditional mining communities--Carbon County (coal) and Grand County (uranium and potash) --we found religious values focused more on the heterogeneity of religious beliefs, "any church affects the quality of all the town's citizens, be it LDS or other, we have an Assembly of God church, Baptist church, Catholic, and Kingdom Hall." In both traditions, though, religion was an important value.

The value 'love' is difficult to interpret; while the term is diverse and ambiguous, it appeared too frequently $(6 \%$, over 50 times ) in respondents' statements to be ignored. These expressions ranged from "my children love to go to the library" to "my church has taught me a new depth of love." Many expressed their strong sense 12 of place, saying "we love it here," or "I love" one feature or another: "Just knowing that the red rock canyons that we love surround us." These value expressions show respondents' strong attachments and sense of place with this region.

Variations on the term 'friends' were identified in 30 photo explanations; and 20 statements included the importance of 'neighbors.' These were closely associated with some important value terms noted above such as family and neighborhood. Several people noted the important relationship between 'religion' and 'friendship:' "Church provides spiritual experiences for members and opportunities to meet with families, friends, and neighbors." One respondent stated the importance of this value quite expansively, "SE Utah people are among the friendliest you will find anywhere."

The 'peacefulness and quiet' of this rural area ranked 10th among the value terms used in the photo-logs. Most of the communities surveyed were small and the pace of life there was perceived by the residents as not being nearly so frenetic as others they may have visited or seen portrayed on television. 'Peace and quiet' was expressed about both the countryside and the towns: "Blue Mountain...peace of mind just to look at it," "Clean neighborhoods, quiet and peaceful." 'Nature and natural beauty' was important value terms in this sample (32, $4 \%$ ). The explanations showed a very strong connection and overlap with 'peace and quiet.' Living closer to nature was perceived as contributing significantly to 
peacefulness: "Natural settings provide a place to relax and enjoy nature."

The value 'safety' is positively related to both children and neighborhoods ("quiet, safe neighborhoods where kids can run and play") and with the traditional wide streets with little traffic. Some negative associations with safety were expressed about coal trucks and trains, and abandoned buildings that attract children to potentially dangerous conditions.

A quality-of-life "value profile" of this fivecounty area of southeastern Utah would have to emphasize the premier importance of 'children,' and of values closely associated with children: 'education,' 'family,' 'sense of community,' 'safety,' and the 'religious values' that guide children. The 'beauty' of the area--in town as well as the dramatic beauty of the mountains, desert, and red-rock canyons and the 'rural character' of the landscape, its 'peace and quiet' and the strong connection to 'nature' make up a second cluster of values essential to quality of life to this region.

\section{Environmental Values}

Statements associated with natural landscape photo-subjects (desert, mountains, water features) and photo-explanations about landscape aesthetics were sorted into categories of environmental values adapted from King's (1966) typology of wildlife values. The environmental values included aesthetics; recreational, natural, social, commercial, and historical values; and negative impacts (Tables C-4 and C-5).
The strongest environmental value related to southeast Utahans' quality of life was 'aesthetics' (Table C-4). One hundred seventeen statements out of $387(30 \%)$ listed 'aesthetics' as the reason for photos taken in the landscape. 'Recreational values' were second, overall (94 statements, 24\%) among environmental values. Many of the expressions of recreational value followed 'aesthetics:' "These mountains are beautiful, and we love to camp there." 'Natural values' (79 statements), including expressions of the restorative value of nature (solitude, finding some peace and tranquility), made up $20 \%$ of the statements.

The landscape also contributed to the social quality of life in SE Utah (41 statements, $11 \%$ ) by means of sharing the experience of the countryside with children, family, or friends. The proximity and accessibility of the mountains, desert, forest, and lakes were deliberately selected by some respondents, i.e., they chose to live close to these environmental amenities so they could share them with their families. The value of the landscape for making a living, or for attracting tourists (commercial value), was listed in 29 statements, about $8 \%$ of the 'environmental value' explanations.

Some negative value statements pointed out damage to the landscape, or pollution of air and water; these constituted 5\% of the environmental value statements. The last category, 'historical value,' accounted for only $8(2 \%)$ of the environmental quality-of-life value statements. Table C-5 shows the distribution of these environ- 
mental quality-of-life values across counties. Again, these are provided to illustrate distributions within each county, not for comparison among counties.

Some residents in this area of Utah have a reputation for disliking "environmentalists," but there is clear evidence that local people in the canyon country have a strong affinity for the open, varied natural environment which surrounds their communities. The beauty of the landscape, the value of recreation in natural settings, and being able to share those experiences with family and friends are strong value components of their quality of life.

\section{Perceptually Important Nodes}

As noted above, Perceptually Important Nodes [PINs] are geographic features photographed by $10 \%$ or more of the participants in each county sample. Locations that were identified several times in the follow-up survey question about "special places" (see page 19) were added to those multiple photographic hits. PINs, then, represent specific locations and particular features that are important to several residents' quality of life. PIN collages, made up of respondents' images and quotes, are being created for these specific sites. These PIN sites are being located, recorded, and "hot-linked" as a layer of a social science, geographic information system [GIS]. These results (and other results from related research conducted on the Colorado Plateau) are being developed for the Southeast Utah canyon country. This location-based information will be made available via the
World Wide Web to all local, regional (e.g., CCP), state, and federal agencies with land and resource management responsibilities in the region, as well as to the public (visit our web site at http://www.mesc.usgs.gov/seias).

Table C-6 lists PINs by county. The numbers in the lower right corner of each cell in this table indicate the number of respondents who identified the particular feature or location. Each county in the study region has a dozen or more places that have been independently identified by several local residents as being important to their quality of life. These PINs include 10 city parks, 8 lakes and reservoirs, 8 schools and colleges, 7 mountains or ranges, 5 museums, 5 canyons, 4 community pools, 4 health facilities, 4 National Parks, 3 cultural sites, 3 golf courses, 2 each of churches, libraries, ball fields, junk yards, and others. Intown locations (e.g., schools and museums) constitute $41 \%$ of the PIN locations and out-of town, countryside locations comprise $37 \%$. A third category, naturein-town (e.g., parks, walkways), is a blending of town and landscape and comprises $22 \%$ of the PINs. 


\section{Recapture Reservair}

\section{Water Supply/Storage:}

Water from the mountain is life itself for the community; it is critical in this dry area. Water has been extremely important from the time this community was settled; gives us peace of mind to have some storage. The reservoir supplies water from the city; provides farmers

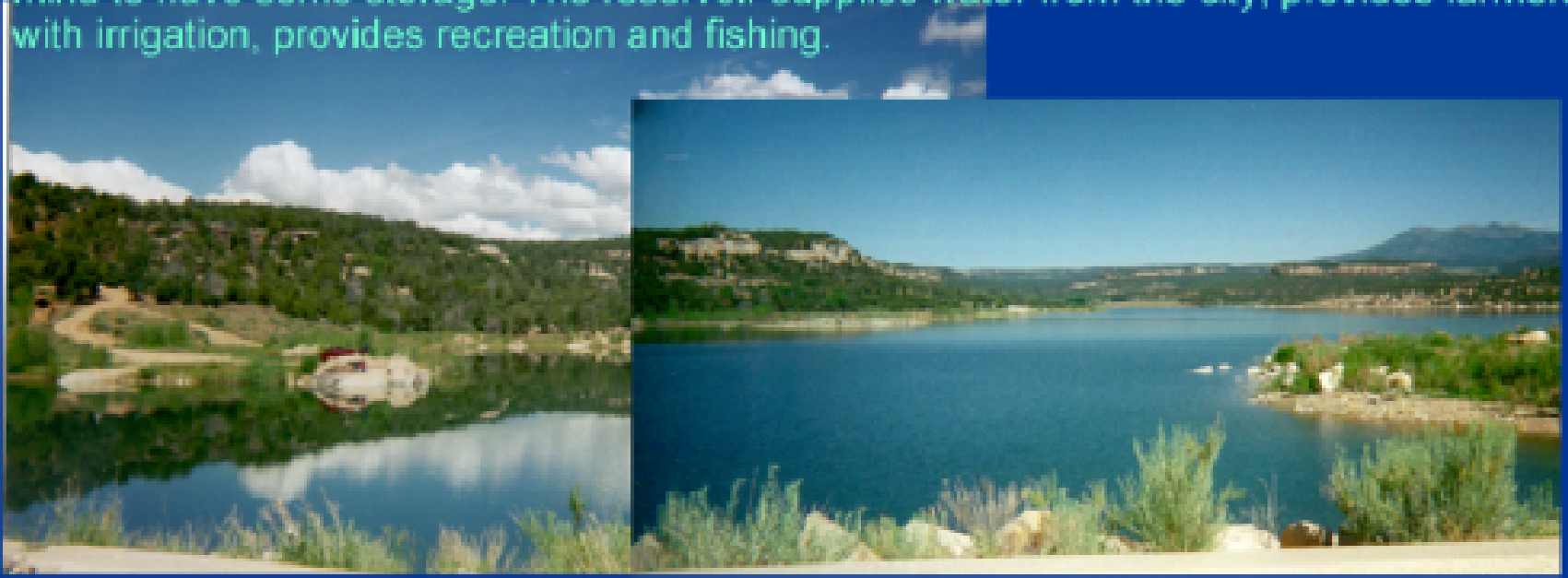

\section{BSGRSATIONB}

Recreational opportunities for locals and nonlocals; fishing and boating, you can swim, ski, fish, or just play at this reservoir. Some important aspects of life here are recreation, hunting, fishing, camping, and clean air

\section{Beauty and Nature:}

The reservoir adds beauty; it affords a beautiful and useful area; scenic and natural settings provide a place to relax and enjoy nature. 


\section{The Follow-Up}

The survey, mailed as a follow-up to the camera exercise, contained four general sets of questions intended to further clarify what community or countryside elements are important to residents' quality of life: (1) community satisfaction and unique qualities, (2) places that have a special personal meaning or importance, (3) the importance of tourism and whether it should increase or decrease, (4) changes that would help maintain or improve community quality of life. In addition, respondents were asked a series of basic demographic questions.

\section{Community Satisfaction}

Several questions were used to measure community satisfaction: first, respon- dents were asked how satisfied they were with their community as a place to live (on a 7-point scale where $1=$ completely dissatisfied and $7=$ completely satisfied). Respondents seem to be quite satisfied with their communities as places to live (Figure 2, and Table D-1). All community satisfaction ratings were high, ranging from 5.5 (Emery County) to 5.9 (Wayne County).

Another question related to community satisfaction, asked residents to rate the importance of the surrounding natural environment to their quality of life. Figure 3 and Table D-2 show the county scores, based on a 7 -point scale where $1=$ not at all important to $7=$ extremely important.

Figure 2: Community Satisfaction

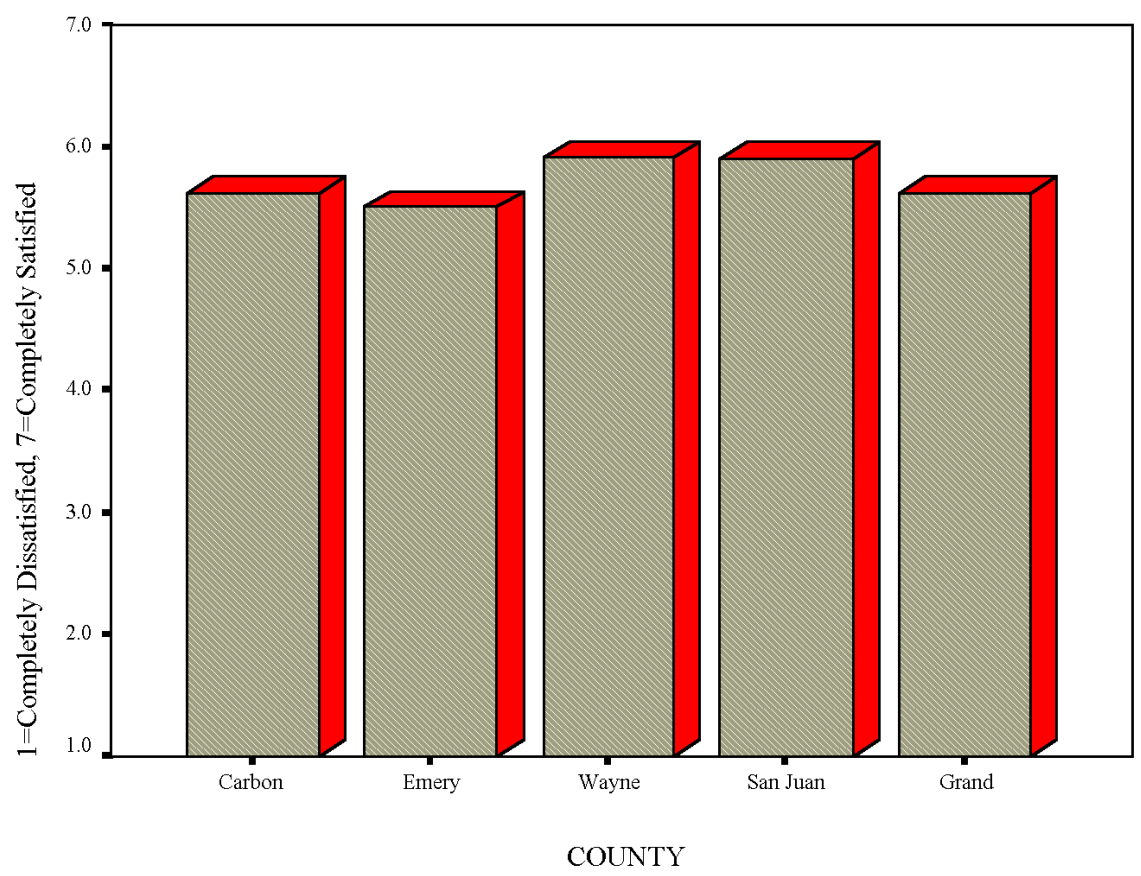


Figure 3: Importance of Surrounding Natural

Environment to Quality-of-Life

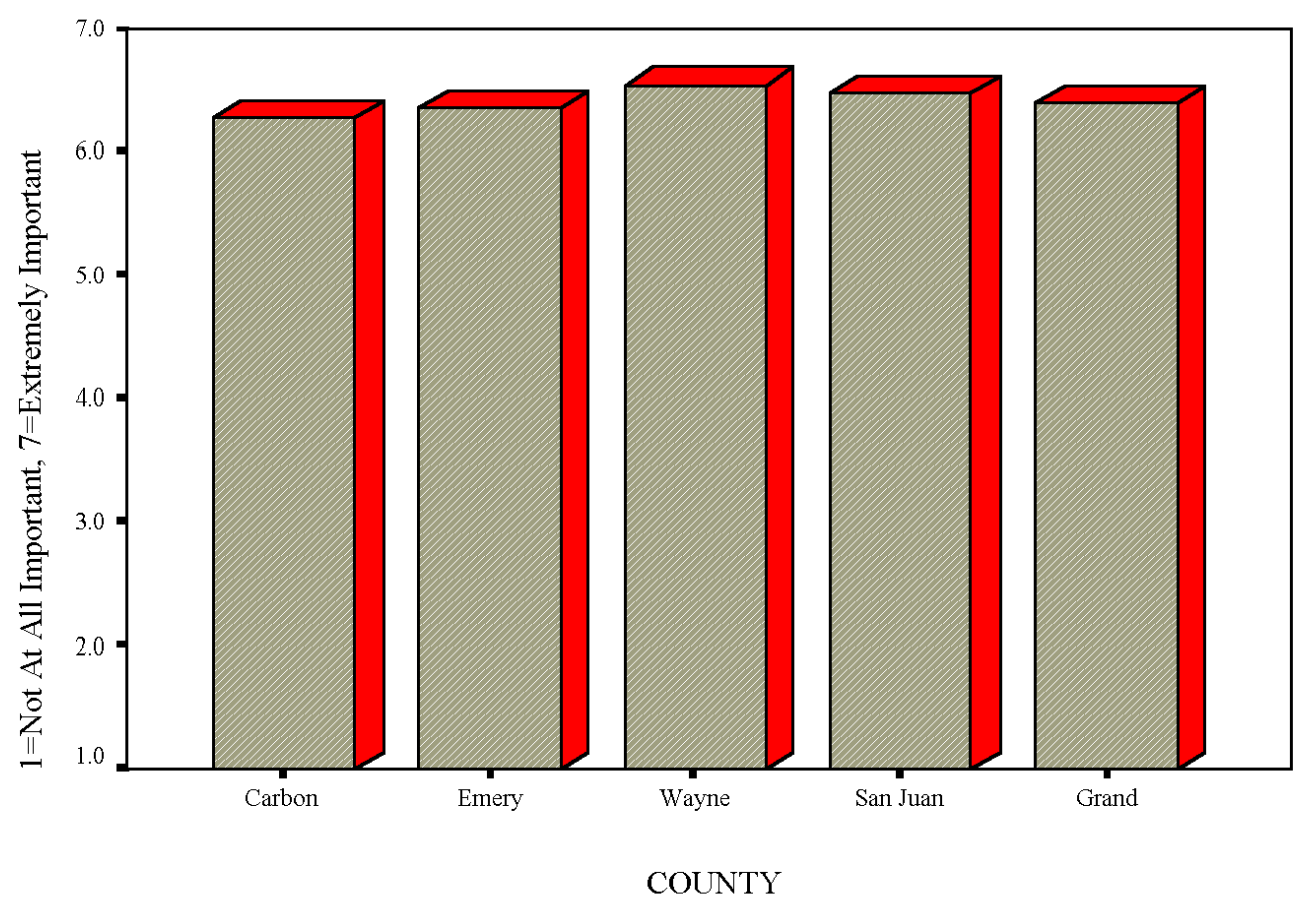

Most respondents felt the natural environment was 'important' to 'extremely important' to their quality of life, with mean scores ranging from 6.2 in Carbon County to 6.5 in Wayne County. The lowest rating any individual respondent gave was "3." The high means and low standard deviations (see Table D-2) indicate that the vast majority of respondents in all five counties felt the natural environment was a very important aspect of their quality of life.

Respondents were asked to list up to three things that they think of when asked, "What is especially good about living in this community?" (Table D-3). They were asked a second open-ended question about how their community is "unique, what distinguishes it from other communities?" (Table D-4). The results in these two tables are quite parallel, so the two data sets are summarized in Table 6.

The natural environment (101 responses, $30 \%)$ tops this list in community quality. Component qualities of natural environment were the physical environment itself, scenic beauty, climate, closeness to nature, lack of pollution, and availability of recreational opportunities. For the second general quality, community character (71 responses, $21 \%$ ), small town atmosphere, lack of congestion, and peace and quiet dominated the list. Friendliness and sociability are important components of people and neighborhoods (63 responses, 19\%). The opportunities (27 responses, 8\%) people viewed as important were the schools, services, churches, and jobs. 
Safety-related qualities $(15,5 \%)$ were perceptions of low levels of fear about crime or gang problems in the communities. These statements of what is "especially good" and "unique" about the community are closely related to the value statements associated with the photographs, for example: Scenic beauty, nature and natural environment; Rural character, peace and quiet, and sense of community; People--friends and neighbors, children and family; Education and good schools; Church and religion; and Safety.

\section{Table 6: Summary of the factors SE Utah residents thought of when asked: (a) "What is es- pecially good about living in this community?" (first, second, and third response) and (b) "How is your community unique?"}

\begin{tabular}{|c|c|c|c|c|c|}
\hline Variable & $\begin{array}{c}\text { Summary }^{1} \\
\begin{array}{c}n=336 \\
n \quad(\%)\end{array}\end{array}$ & $\begin{array}{c}\text { (a) } 1 s t \\
\text { Response } \\
n=87 \\
n \quad \%)\end{array}$ & $\begin{array}{c}\text { (a) } 2^{\text {nd }} \\
\text { Response } \\
n=86 \\
n \quad \%)\end{array}$ & $\begin{array}{c}\text { (a) 3rd } \\
\text { Response } \\
n=85 \\
n \quad \%)\end{array}$ & $\begin{array}{l}\text { Unique (b) } \\
\qquad \begin{array}{l}n=78 \\
n \quad \%)\end{array}\end{array}$ \\
\hline $\begin{array}{l}\text { NATURAL/ENVIRONMENT: } \\
\text { Physical/Natural environment } \\
\text { Scenery/Beauty of area } \\
\text { Weather/Climate } \\
\text { Location/Closeness to natural environment } \\
\text { Clean air/No pollution } \\
\text { Outdoor recreation activities }\end{array}$ & $\begin{array}{l}\frac{101}{36(10.7)} \\
19(5.6) \\
14(4.1) \\
12(3.5) \\
11(3.2) \\
9(2.6)\end{array}$ & $\begin{array}{l}5(5.7) \\
5(5.7) \\
5(5.7) \\
1(1.1) \\
5(5.7) \\
3(3.4)\end{array}$ & $\begin{array}{l}3(3.5) \\
8(9.3) \\
3(3.5) \\
3(3.5) \\
6(7.0) \\
3(3.5)\end{array}$ & $\begin{array}{l}4(4.7) \\
4(4.7) \\
6(7.1) \\
5(5.9) \\
-- \\
2(2.4)\end{array}$ & $\begin{array}{c}24(30.8) \\
2(2.6) \\
- \\
3(3.8) \\
-- \\
1(1.3)\end{array}$ \\
\hline $\begin{array}{l}\text { COMMUNITY CHARACTER: }(21.1 \%) \\
\text { Small town atmosphere/rural character/size } \\
\text { No congestion } \\
\text { Peace and quiet } \\
\text { Location attributes } \\
\text { Sense of community/Trustworthy people } \\
\text { Clean town/Fixing up homes } \\
\text { No two houses look alike }\end{array}$ & $\begin{array}{l}\frac{71}{35(10.4)} \\
14(4.1) \\
9(2.6) \\
4(1.1) \\
3(.8) \\
3(.8) \\
3(.8)\end{array}$ & $\begin{array}{l}16(18.3) \\
5(5.7) \\
6(6.9) \\
1(1.1) \\
1(1.1) \\
\quad-- \\
--\end{array}$ & $\begin{array}{c}10(11.6) \\
3(3.5) \\
-- \\
-- \\
-- \\
-- \\
-\end{array}$ & $\begin{array}{l}3(3.5) \\
6(7.1) \\
3(3.5) \\
3(3.5) \\
-- \\
1(1.2) \\
-\end{array}$ & $\begin{array}{c}6(7.7) \\
-- \\
-- \\
-- \\
2(2.6) \\
2(2.6) \\
3(3.8)\end{array}$ \\
\hline $\begin{array}{l}\text { PEOPLE/NEIGHBORHOOD: } \\
\text { Friendliness/Care of people } \\
\text { Social/People } \\
\text { Diversity of people } \\
\text { Familiarity/Know everyone }\end{array}$ & $\begin{array}{c}\frac{63}{30(8.9)} \\
20(5.9) \\
7(2.0) \\
6(1.7)\end{array}$ & $\begin{array}{c}6(6.9) \\
12(13.8) \\
-- \\
--\end{array}$ & $\begin{aligned} 14 & (16.3) \\
2 & (2.3) \\
2 & (2.3) \\
1 & (1.2)\end{aligned}$ & $\begin{array}{l}9(10.6) \\
5(5.9) \\
1(1.2) \\
3(3.5)\end{array}$ & $\begin{array}{l}1(1.3) \\
1(1.3) \\
4(5.1) \\
2(2.6)\end{array}$ \\
\hline $\begin{array}{l}\text { OPPORTUNITIES: } \\
\text { Good schools } \\
\text { Variety of activities } \\
\text { Facilities/Services } \\
\text { Chapel/Church/Worship } \\
\text { Jobs/Work }\end{array}$ & $\begin{array}{l}\frac{27}{10(2.9)} \\
6(1.7) \\
4(1.1) \\
4(1.1) \\
3(.8)\end{array}$ & $\begin{array}{l}3(3.4) \\
1(1.1) \\
1(1.1) \\
-- \\
--\end{array}$ & $\begin{array}{l}2(2.3) \\
1(1.2) \\
2(2.3) \\
2(2.3) \\
\quad--\end{array}$ & $\begin{array}{l}5(5.9) \\
3(3.5) \\
1(1.2) \\
1(1.2) \\
3(3.5)\end{array}$ & $\begin{array}{c}1(1.3) \\
-- \\
1(1.3) \\
--\end{array}$ \\
\hline $\begin{array}{l}\text { SAFETY: } \\
\text { Low levels of fear/crime } \\
\text { Crime/Safety }\end{array}$ & $\frac{15}{11(3.2)}$ & $\begin{array}{c}4(4.6) \\
--\end{array}$ & $\begin{array}{l}2(2.3) \\
3(3.5)\end{array}$ & $\begin{array}{l}4(4.7) \\
1(1.2)\end{array}$ & $1(1.3)$ \\
\hline $\begin{array}{l}\text { FAMILY: } \\
\text { Family/Family atmosphere } \\
\text { Good place to raise a family }\end{array}$ & $\begin{array}{l}\frac{11}{7(2.0)} \\
4(1.1)\end{array}$ & $\begin{array}{l}1(1.1) \\
1(1.1)\end{array}$ & $\begin{array}{l}3(3.5) \\
2(2.3)\end{array}$ & $\begin{array}{l}3(3.5) \\
1(1.2)\end{array}$ & $\begin{array}{l}-- \\
--\end{array}$ \\
\hline $\begin{array}{ll}\text { LIFESTYLE: } & (0.9 \%) \\
\text { Remote/Isolation } & \end{array}$ & $3(.8)$ & -- & -- & -- & $3(3.8)$ \\
\hline MISCELLANEOUS: & $6(1.4)$ & $\overline{--}$ & $1(1.2)$ & -- & $5(6.5)$ \\
\hline NOTHING: & $4(1.1)$ & -- & $\overline{--}$ & $\overline{--}$ & $4(5.1)$ \\
\hline
\end{tabular}




\section{Special Places}

One section of the follow-up survey was dedicated to identifying areas or places in Southeastern Utah that have special meaning or importance to residents. Respondents were asked to "think about . . . places in Southeastern Utah that have a special meaning or importance to you." For each special place, respondents were asked to provide the name and location, to list the things they do there, and to state the reasons that place has special meaning for them. Residents were also asked to identify the land ownership (e.g., federal, state, private), if they could.

Respondents were asked to identify up to two special places; 86 listed a first special place, and 74 listed a second one. The Manti-La Sal National Forest was the most frequently named special place (16 $=10 \%$ ), but this was in four of the five counties (all except Wayne County), and the Manti-la Sal NF extends into all five counties. Therefore several different specific locations probably were intended. Arches National Park and Blue Mountain in San Juan County were listed most often as specific special places (10 each, 6\%; see Table D-5). The San Rafael Swell in Emery county was listed third most often $(8=5 \%)$, the Huntington Canyon/Skyline Drive area that crosses the Emery-Carbon County boundary was fourth $(7=4 \%)$ and Capitol Reef National Park was fifth ( $5=3 \%)$. In general, however, there were relatively few commonalties among specific special places that people listed; 76 out of the 89 places listed (85\%) were mentioned by only one or two respondents. Seven respondents listed "my home" as a special place for them, but of course, these represented seven different locations. The special place results were combined with the photograph location information to help identify specific Perceptually Important Nodes in southeast Utah that are essential for local residents' quality of life. These PIN results have been discussed above and are included in Table C-6.

Respondents were also asked if they knew whether their first special place was owned by private, county, state, or federal sources (Table D-6). Fifty percent of the special places were identified as federal property and $17 \%$ as private. Fewer were on state (12\%) or county (11\%) land, and 21 people (11\%) stated they did not know who owned their special place land. While there are bound to be some errors in these judgements, it is safe to say that the majority of residents' special outdoor places were on public land of some sort. Three-quarters of the special places listed, ranging in scale from a city park to the San Rafael Swell, were natural areas managed by local, state, or federal agencies.

One way to gain insight into how residents value the area in which they live is to find out what they do in areas that are of particular importance to them. This question was asked of the survey respondents concerning their "special places." The responses to this question show that recreation-- consumptive and nonconsumptive and motorized and nonmotorized--plus appreciation of the surrounding environment made up the vast 
majority (86\%) of these residents use of their special places (see Table D-7). Hiking, fishing, camping, sightseeing, hunting, picnicking, and motorcycling made up nearly two-thirds (64\%) of these activities. Emery County residents seem to be somewhat more oriented towards consumptive, "collection" and motorized recreation, and a little less focused on the aesthetic values of the environment than respondents from other counties.

The reasons respondents gave for the special meaning of their "special places" were aggregated into six general categories, plus a seventh 'miscellaneous' category (Table $\mathrm{D}-8$ ). The reasons given are similar to the results of the camera exercise. The most frequently stated reasons had to do with the 'environment' of their special places (32\%): scenic beauty, remote solitude, wildlife, and open spaces. Second were social reasons (27\%): these special places can be shared with 'family and friends,' become part of a family tradition that keeps on providing fond memories. The survey respondents mentioned ease of 'access, proximity, and familiarity' 22 times (10\%) and thus the frequency with which the special place can be used was shown to be important. 'Recreation,' 'economic use,' and 'personal or emotional' reasons were offered 17 times (8\%) for each of these categories.

\section{Tourism}

Regarding tourism, respondents were asked to indicate how important this industry was to the economic well-being of their community, on a 7-point scale where $1=$ not at all important and $7=$ extremely important. Respondents from all counties except Emery indicated tourism was generally important (Figure 4). Grand and Wayne County each have major tourist attractions (Arches National Park, Canyonlands National Park, Slick Rock Trail in Grand County; Capitol Reef National Park in Wayne) and respondents in those two counties felt that tourism was very important to the economic wellbeing of their communities.

Respondents were then asked if they would prefer less or more tourism in their county than currently exits, using a scale of $1=$ much less, $4=$ no change, and $7=$ much more tourism (Figure 5). All five counties had mean responses between 4.0 (Grand County) and 5.0 (Carbon County) for this question; residents seemed to be relatively satisfied with the current or a slightly increased level of tourism in their counties. Even in Emery County, where importance of tourism was listed the lowest, respondents wanted a slight increase. Respondents from Grand County, a county that has seen a huge increase in tourism over the past decade, preferred "no change," on average, in tourism numbers.

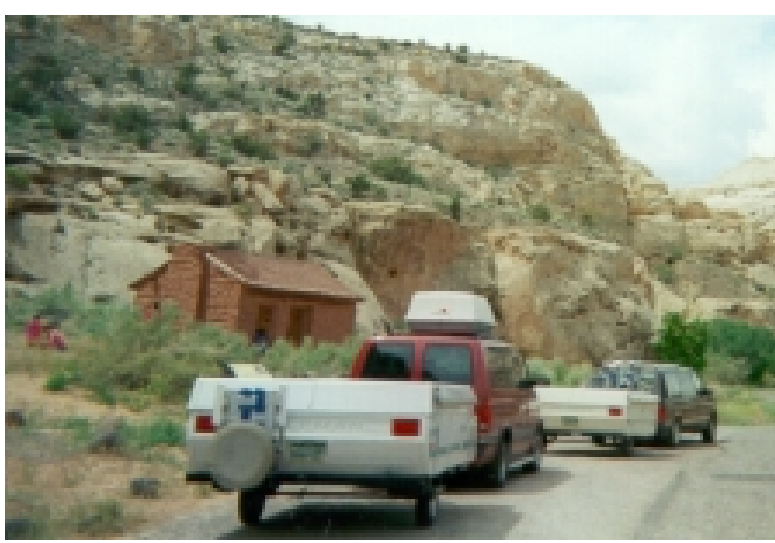


Figure 4: Importance of Tourism

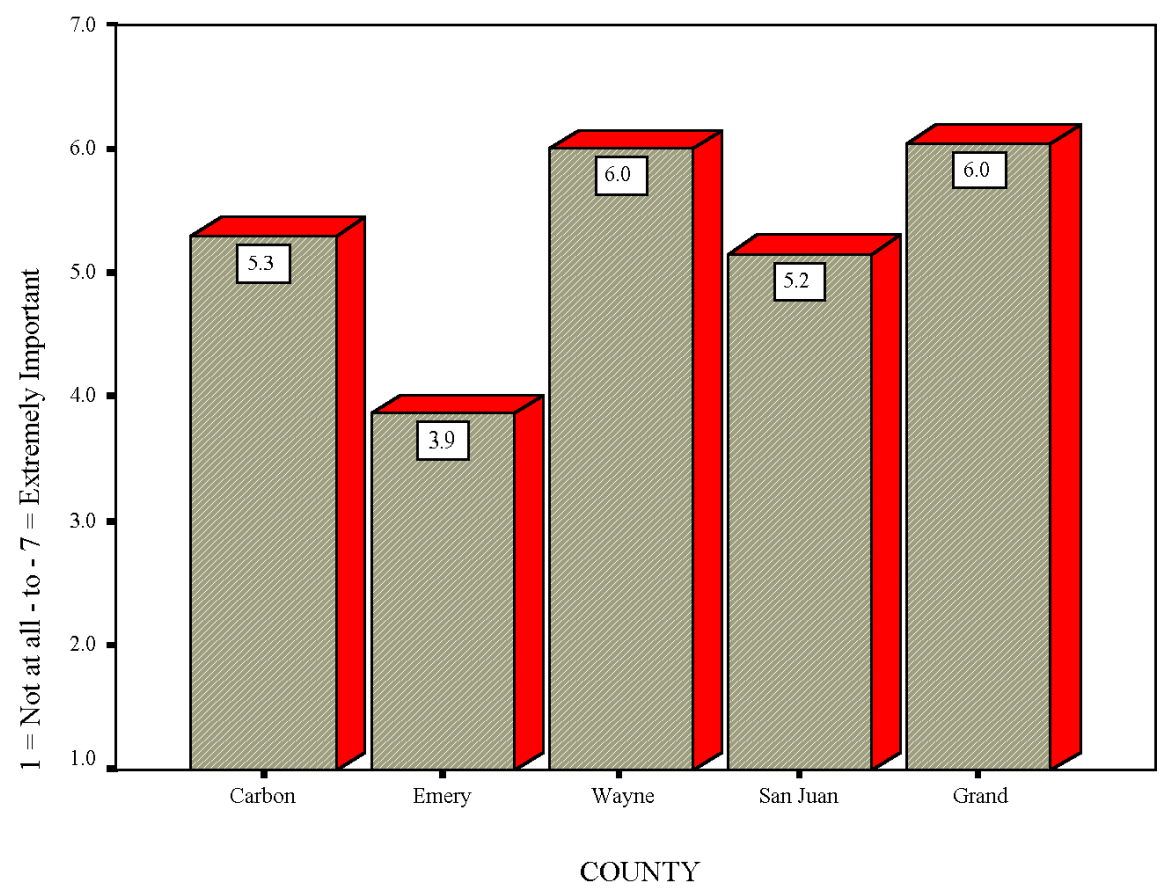

Figure 5: Prefer More or Less Tourism

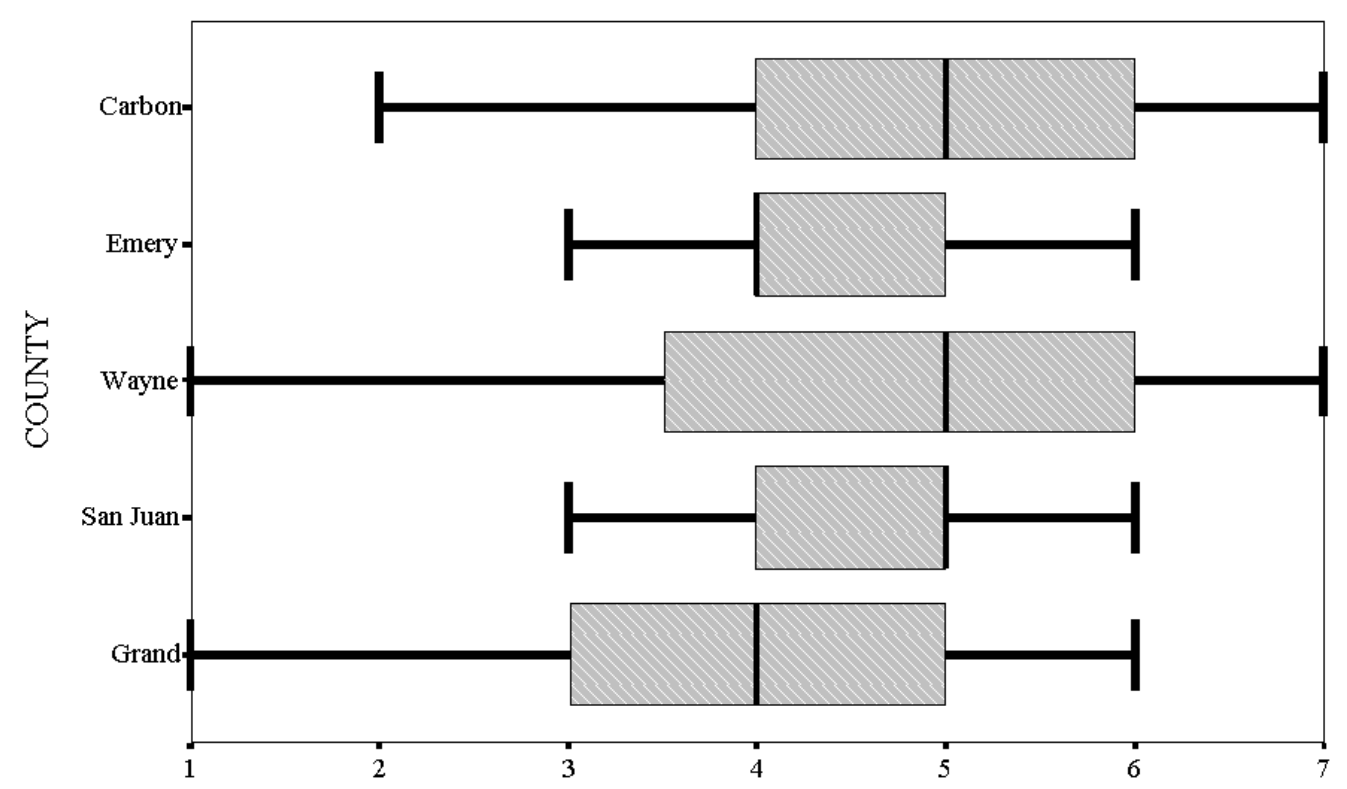

1) Scale: $1=$ Much Less Tourism, $4=$ No Change, $7=$ Much More Tourism

2) Mid line is Median, Line segments show range of responses 


\section{Changes to Improve Quality of Life}

Respondents were given a list of twelve items that resource planners or managers might be able to influence, which in turn might affect community quality of life. Respondents were asked to rate each item on a 1-7 scale where $1=$ greatly $d e$ crease to improve quality of life, $4=$ no change, and 7 = greatly increase to improve quality of life (Figure 6, Table D-9 and Figures D-1a \& b).

Respondents wanted to see increases, to improve quality of life, in 'jobs in traditional county industries' (mean $=5.4$ ), 'attractions and services to encourage visitors to stop rather than just drive through' (5.2), and 'tourism and recrea- tion jobs for local residents' (5.0). Residents wanted to see 'minerals and energy extraction' increase to augment quality of life (5.0), especially in San Juan County (5.5). It is interesting to note that residents throughout the area would like to see a slight increase in 'zoning to protect agricultural lands and open space' (4.8).

The desire for more 'parks and open space' was proportional to the size of community in which respondents lived (Figure D-1a): Price in Carbon County and Moab in Grand County were the two largest communities surveyed and these two counties were most desirous of more parks; Wayne County, where communities were the smallest, wanted the least.

Figure 6: Variables to Improve Quality of Life

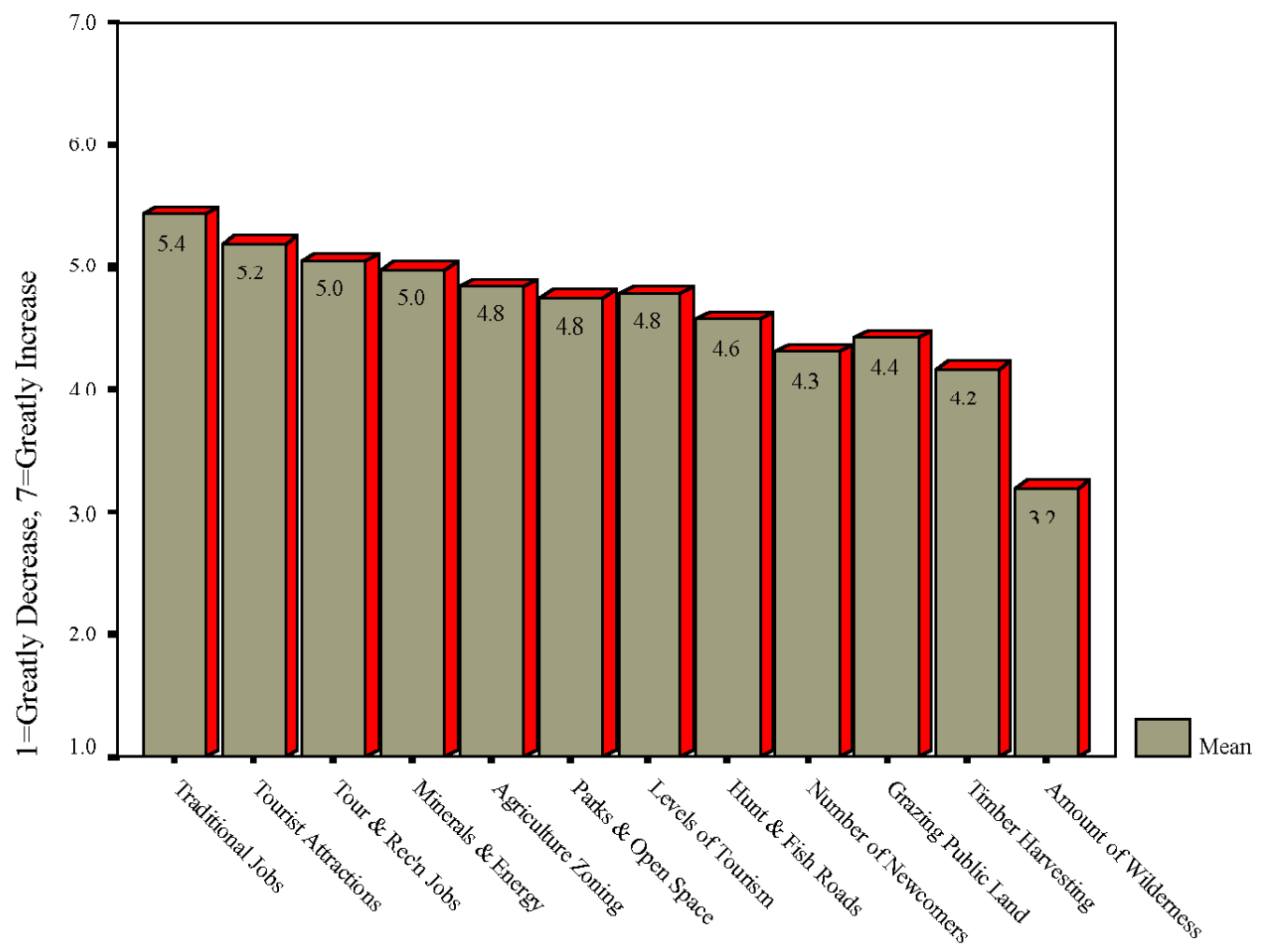


Average responses also indicate residents wanted little increase or change in most commodity-related activities, aside from 'minerals and energy mining,' such as 'road access to hunting and fishing areas' (4.6), 'grazing on public lands' (4.4), and 'timber harvesting' (4.2).

It is interesting to compare local respondents' desires for tourism and outdoor recreation with their desires for new residents. Grand County, which has been experiencing a significant influx, both in tourism and new residents, was the only county wanting to see no change in the rates of tourism (4.1) or new residents (4.0). Other counties seemed interested in a moderate increase in tourism attractions (5.3), tourism jobs (5.2) and levels of tourism (5.0) while wanting the level of immigration to stay unchanged (4.3). San Juan County seemed to recognize that growth in new residents (4.8) goes along with increased tourism.

The only variable, in this list, with an overall mean below 4.0, suggesting residents wanted a decrease in order to improve quality of life, was 'the amount of wilderness in Southeastern Utah' (3.2). Although wilderness may be paradise enou for some, it does not seem to be paradisiacal for residents of southeastern Utah at this time. Emery County (2.3) and San Juan County (2.4) respondents were interested in having far less wilderness.

\section{The Respondents}

Table D-10 shows that, out of the 87 respondents who answered the follow-up survey, most were Caucasian (83\%), between the ages of 36 and 75 (70\%), and a majority were female (58\%). Thirty percent were over the age of 65 , and only $17 \%$ were under the age of 35 . Twentynine percent had a high school degree or less education, 58\% had some college or a bachelor degree, but only (13\%) had taken graduate training. Nevertheless, this was a rather well-educated sample, with $71 \%$ having some college or more education.

The average household income for followup survey respondents was relatively low; while $41 \%$ stated their income was between \$30,000 and \$59,000, 47\% make $\$ 29,000$ or less, and only $12 \%$ indicated an income of $\$ 60,000$ or more. More than a third of the respondents worked in managerial/professional occupations $(37 \%)$ and another third were in service occupations (32\%). Thirteen percent listed technical/sales/administration occupations and another 10\% listed operator/laborer type occupations.

\section{Response Bias}

The camera exercise and the follow-up survey were completed by fewer respondents than anticipated (41\% and 60\%, respectively), therefore a telephone survey was conducted of 95, randomly selected, non-respondents from the original contact sample. These telephone recontacts were asked the same demographic questions as in the follow-up survey, and the two samples were compared (see Table D11). Differences in demographic characteristics, in this comparison, give us an idea of any biases in the study's repre- 
sentation of the resident population of southeastern Utah.

The camera/follow-up respondents $(\mathrm{CF})$ are similar to the telephone recontacts (TR) in several respects. First, women outnumbered men in both samples (CF $58 \%$; TR $61 \%$ ), and the majorities of both samples were between 36 and 60 years of age (CF 55\%; TR 59\%). The two groups were fairly proportional across occupations except for Management/ Professional (CF 37\% > TR 26\%) and Technical/Sales/Admin. (CF 13\% < TR 20\%). There is not much difference in overall average education, although more respondents received college $(\mathrm{CF} 21 \%>\mathrm{TR}$ $13 \%$ ) and graduate degrees (CF 13\% > TR $4 \%)$. Income is also fairly comparable across the two samples except for the $\$ 20$ - 30K range (CF 25\% > TR 9\%). Ethnicity appears to be different for "whites" and "native Americans," but this may be a result of Anglos, who were born in the United States, choosing "Native Ameri- can," the first ethnic category listed in the printed surveys.

The most significant difference between these two samples is in the numbers of participants over 65 years old (Table D11). Fully $30 \%$ of the $\mathrm{CF}$ respondents were age 65 or older, compared to $7.6 \%$ for the TR sample; the CF average age was 53 compared to 41 for TR. These CF age differences are related to the high proportion of respondents who reported their occupational status as retired (37\%; see Table D-10). The camera exercise requires more effort than most mail-back surveys. Respondents had to travel to several locations in order to take photographs of places or items that were important to their quality of life, many of which were out of town. It is probable that retired persons, having more free time, were better able to take the time necessary and thus appear disproportionately in the CF survey.

\section{In Sum}

What have we learned, then, about quality of life in Southeast Utah? First, it is important to acknowledge the limitations of this set of information. These responses reflect the feelings of some 144 (camera exercise) to 87 (follow-up survey) residents of southeast Utah, spread over the 5-county area from Carbon County south through San Juan County. Older residents tended to participate in higher numbers than the rest of the population. However, the respondents were nearly all permanent residents (98\%) and their responses represent a lot of experience with 24 the region: the average time in residence was 37 years.

Many of the results from the various measures reported here reinforce one another. Children, family, friends and friendly neighbors are central to quality of life in southeastern Utah. These are shown by several measures: values expressed, unique qualities, what is good about the community, and why special places are important. These social parameters combine with physical features of the community - the well kept homes, 
the flower gardens, the wide streets shown in the photo subjects. All of these aspects of "community aesthetics" create a sense of neighborhood and community that residents treasure. Their children are safe here, and learn important religious values, respect for nature, and the history and prehistory of this region (values, what is good and unique about the community). It is not surprising, then, that residents rate their satisfaction with their community so high (5.6 out of a possible 7.0).

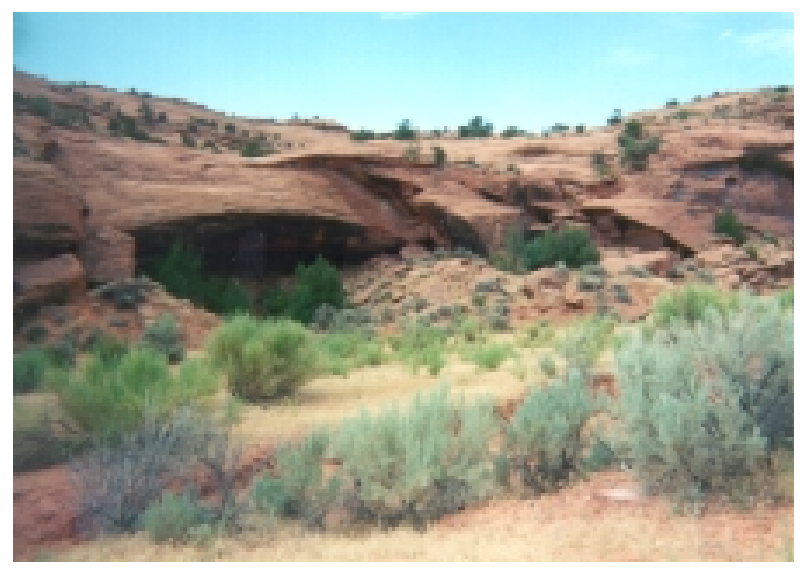

The beauty of the canyon country, the scenic vistas, the mountains, the red rock cliffs and canyons, the desert, lakes and reservoirs (photos, PINs -- special places and why they are important, values, and what's good and unique) are there to be enjoyed from a short distance every day and are easily accessible for recreation, peace and quiet, and enjoying nature (what people do in special places). Children learn to love and respect the environment in these settings. The rural character of the area is important to residents of the towns as well as the countryside. Seeing the mountains as the backdrop for irrigated fields or open cattle range is important to southeast Utah residents. All of these features are evidenced in the value statements, photo subjects, and the desire to protect agriculture and open space. These respondents rated the importance of the surrounding natural environment to their quality of life as 6.4 (on the 7 point scale)-very important.

The National Forests, National Parks, and State Parks and reservoirs are important to the people of southeast Utah. This is to be expected, given that $80 \%$ of the land area in these five counties is either Federally or State owned. Half of the "special places" were identified as being on Federal lands and another $22 \%$ on State or county land.

What can happen to make the quality of life better? Respondents would like to see a resurgence of traditional jobs, but also some increase in tourism and outdoor recreation employment. They would prefer to attract tourists to stay over in their county, but they want the rural character of the area to be protected by zoning of agriculture and open space. On the other hand, they also would like wilderness designation decreased. The county with the greatest recent tourism influx, Grand County, is the most leery of increasing tourism and the associated resident population growth. Most of the other counties expressed wanting tourism to increase, but without concomitant population growth, which Grand County's experience suggests may not be possible. 
PINs, sites important to several people, most often are locations where change or development might be limited, or at least conducted carefully to avoid destruction or degradation of community landmarks. A few PINs are negative, but nevertheless important locations, where change might be seriously considered to modify or remove visual disturbances. Specifically, for this latter category, removal or clean-up of junky or trashy places in town and in the countryside could do much to enhance community quality of life potentials.

\section{The Research Method-Some Thoughts}

Using resident-employed photography as a means of measuring quality of life is experimental; probably the first application of this research approach to that problem. The camera exercise did not produce as many National Park, National Forest, or BLM land photographs as might have been expected, given land ownership. However, where the photographs were focused somewhat more on town settings than on the surrounding landscape ( $57 \%$ to $43 \%$, respectively), quite the opposite was true with the "special places" identified by residents (18\% to $82 \%$ ) in the follow-up survey. This, we believe, is related to the level of effort that the photo-exercise requires of resident respondents. They must travel from their homes to the locations of importance in order to photograph them. Some of their most important areas may well be fairly remote; close enough to enjoy on vacation or even a long weekend, but too far away for a camera survey. The follow-up survey proves to be very important in obtaining the full breadth of quality-of-life locations.

The camera exercise, however, remains an essential part of the quality-of-life survey. Just as not all aspects of quality of life are visual, neither are they all easily described in words, especially the beauty of important places. The camera puts the respondents in charge, it lets them tell the researchers what is important. As stated by Cherem (1973), one of the originators of the camera method, this technique lets the researcher "see through the eyes of the public." An important value of the photo exercise is the resource it provides for effective communication with (and by) natural resource and land managers/planners. Often, the results of preference research are presented only by means of text, tables and graphs. But pictures, actually taken by the clientele served, are a much more interesting and graphic means of communicating people's desires. The photographs let the resource manager, as well, see through the eyes of their constituents. 


\section{References}

Cherem, G. J. 1973. Looking through the eyes of the public. In Proceedings of Aesthetics Opportunity Colloquium, pp. 52-64. Utah State University, Logan.

King, R.T. 1966. Wildlife and Man. N.Y, Conservationist 20:8-11.

Reis-Ruehrwein, J., Taylor, J., and D. Blahna. 1997. Colorado Plateau Research Collaboration, Kane Creek Study Area. Summary Report. Moab, UT. December 1997.

Shafer, E.L., Jr. 1969. Perception of Natural Environments. Environment and Behavior, 1:71-82.

Taylor, J.G., K.J. Czarnowski, N.R. Sexton, and S. Flick. 1996. The importance of water to Rocky Mountain National Park Visitors: An Adaptation of Visitor Employed Photography to Natural Resource Management. Journal of Applied Recreation Research, 20(1):61-85.

Utah Division of Travel Development. 1997. Road Map for Destination Tourism. Executive Summary. Salt Lake City, UT. February 1997.

\section{Photograph Captions}

\begin{tabular}{|c|c|}
\hline Page & \\
\hline iii: & Community Aesthetics, Moab, Grand County \\
\hline iv: & Landscape Vista Scene, Wayne County \\
\hline vi: & PIN: Colorado River near Moab, Grand County \\
\hline 4: & Community Aesthetics: Home, Wayne County \\
\hline 4: & Landscape Vistas: Abajo Mountains, San Juan County \\
\hline 6: & Business: Open. Bank in Blanding, San Juan County \\
\hline 6: & Peace Park and Prehistory Museum: Price, Carbon County \\
\hline 6: & Water: Donkey Lake, Dixie National Forest near Teasdale, Wayne County \\
\hline 6: & City Parks \& Walkways: Price River Walkway, Helper, Carbon County \\
\hline 7: & Church: LDS Church in Monticello, San Juan County \\
\hline 7: & Agriculture: Tractor Cutting Hay near Ferron, Emery County \\
\hline 7: & Wide Streets: Huntington, Emery County \\
\hline 9: & Human Impacts: Trash Dumped at "the Flats" West of Huntington, Emery County \\
\hline 10: & Value Children: Cottonwood Wash, San Juan County \\
\hline 10: & $\begin{array}{l}\text { City Park: Children playing musical instrument in Rotary Park, Moab, Grand } \\
\text { County }\end{array}$ \\
\hline 11: & Schools: Emery High School, Castle Dale, Emery County \\
\hline 15: & PIN: Recapture Reservoir, San Juan County \\
\hline 20: & Tourism: Tourists near Capitol Reef National Park, Wayne County \\
\hline 25: & Monument Valley Landscape, San Juan County \\
\hline Appendix A: & Boulder Mountain, Wayne County \\
\hline Appendix B: & Mill Creek Walkway, Moab, Grand County \\
\hline pendix C: & San Rafael Swell, Emery County \\
\hline Appendix D: & Electric Lake, Emery County \\
\hline
\end{tabular}




\section{Appendix A:}

\section{The Photo Log}

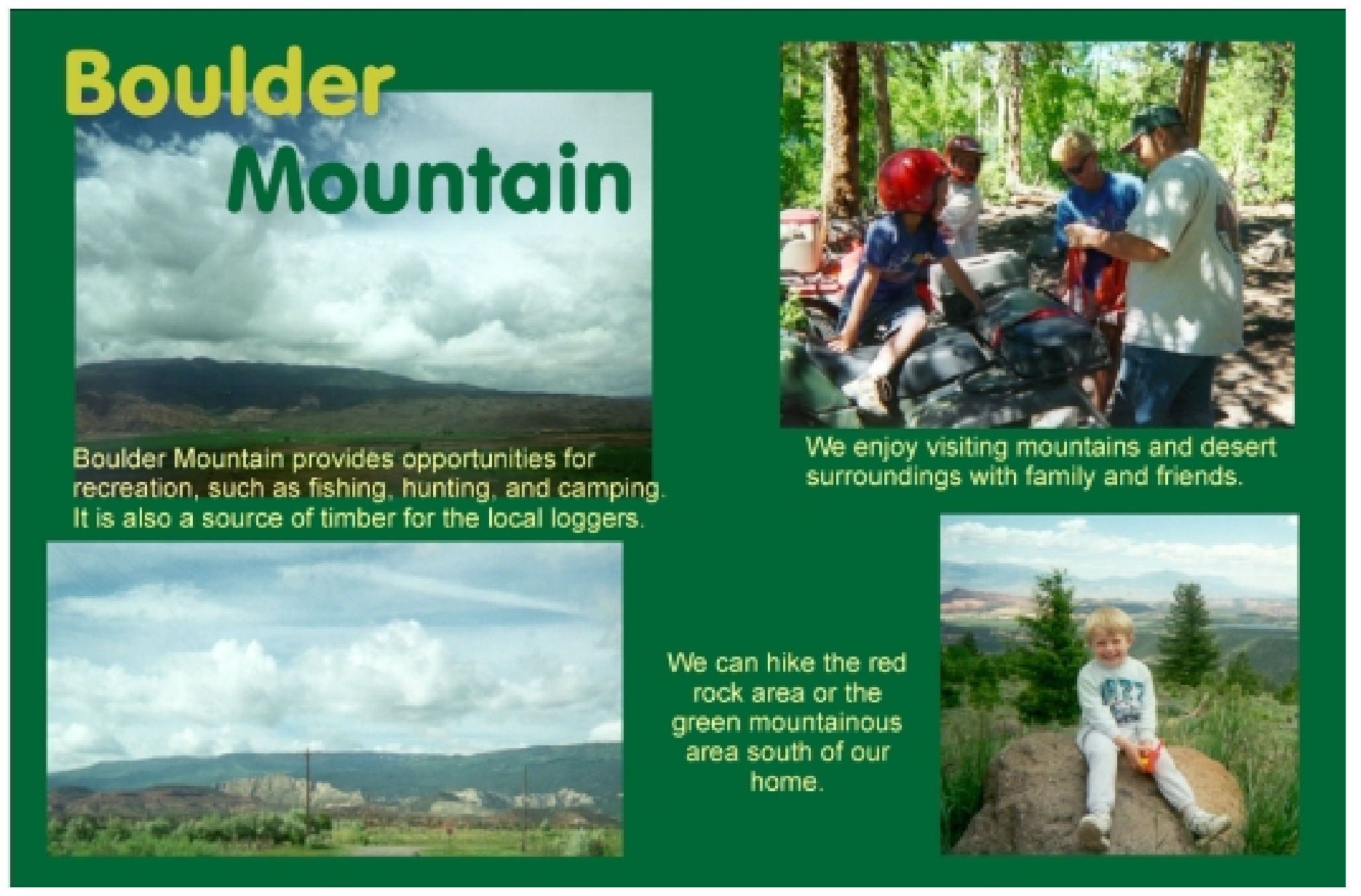




\section{Photo Log}

\section{INSTRUCTIONS}

Many Southern Utah communities have been experiencing rapid growth and change. As local governments plan for these changes and for increasing numbers of visitors, many Utahns are concerned about maintaining their quality of life. Therefore, it is very important community officials find out which elements in each community and the surrounding countryside need to be protected to retain that quality of life.

The goal of this study is to learn what features, places, or activities you think are essential to the quality of life in this area. The task you have agreed to do is capture, on film and in this "photo log" booklet, those aspects of your community and county that most affect your quality of life. Your responses are extremely important in order to accurately represent the concerns and preferences of persons in your area. Your participation is voluntary, and please be assured your answers will be kept strictly confidential.

\section{As you take each photograph, please. . .}

1. Record the subject. (What are you taking a picture of?)

2. Record the location. (Where is it in your community or surrounding countryside?

Identify nearby landmarks, roads, and trails to help pinpoint the location)

3. Record whether it has a positive or negative effect on your quality of life.

4. Comment briefly on why it is important to your quality of life.

Be sure to record the above information in the booklet in the same order as the pictures in the camera.

Thank you for your valuable contribution to this study!

This study is being conducted by Utah State University for the Utah Travel Council and your local county (with collaborative support from the Biological Resources Division of the U.S. Geological Service and the Canyon Country Partnership). The results of this study will be provided to county and local planners. 


\section{Photo \#1 $1^{\text {a }}$}

Subject what are you taking a picture of?

\section{Location Where is it? Use nearby landmarks, roads, trails, etc. to help describe location.}

Does the subject of this photograph affect your quality of life...

$\square$ positively

(Contributes importantly) or negatively

(Detracts importantly)

\section{Explanation}

Why does this feature, place, or activity have an important effect on your quality of life?

${ }^{\text {a }}$ Note: The photo log booklet contained a total of 12 duplicate pages, one for each photograph 


\section{Additional comments}

When you are finished taking your photographs, please put the camera and photo log in the stamped, self-addressed envelope we have provided and place it in the mail! After we receive your camera and develop the film, we will send you a full set of color prints and a copy of your Photo Log booklet. At that time, you will also receive a follow-up survey asking you a few questions about yourself (i.e., age, gender, etc.), your quality of life, and about some of the photos you took. We will need your name and mailing address to send you the photos and questions.

\section{Name}

\section{Street Address}

City State $\quad$ Zip Code

\section{County}

If you have misplaced the envelope, you can mail the camera and booklet to:

Jessica Ruehrwein

Department of Forest Resources

College of Natural Resources

Utah State University

Logan, Utah 84322-5215

\section{Thank you for your help with this study!}

If you have additional questions or comments, please contact Jessica Ruehrwein at (801) 7971009 or Sarah Flick at (970) 226 - 9302. 


\section{Appendix B:}

\section{The Follow-up Survey}

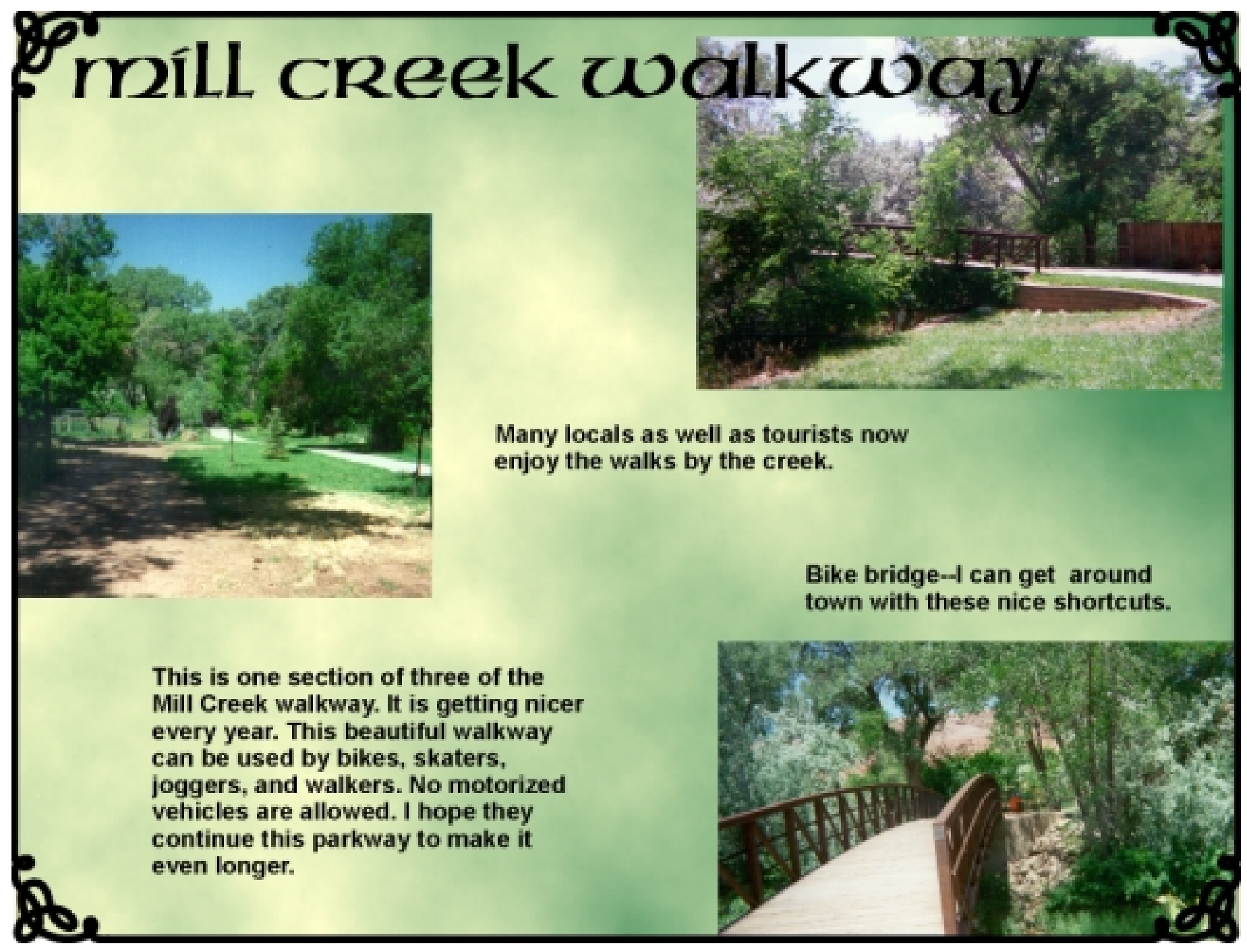


This survey is a follow-up to the photographic study you helped us with, to determine what elements of your community and county are essential to your quality of life. Not all aspects of "quality-of-life" are visible, of course; some important elements cannot be photographed.

1. How satisfied are you with your community as a place to live?

(Please circle the number, on the scale below)

Completely

Dissatisfied

1

2

3

Neutral

4

5

Completely

Satisfied

$6 \quad 7$

2. What are the first three things you think of when someone asks you,

"What is especially good about living in this community?"

First:

Second:

Third:

3. Some people are concerned that communities across America are all starting to look alike. How is your community unique, what distinguishes it from other communities?

If you photographed any of the elements mentioned in question 2 or 3 , please write the photo number, from the back of the photograph, next to the written item.

4. Please indicate how important you feel tourism is, at the present time, to the economic wellbeing of your community. (Please circle a number)

Not at All

Important

12

3

4

45

6

Extremely

Important

7

5. Would you prefer less tourism or more tourism in your county than there is now?

Much Less

1
No Change

4
Much More 
6. Resource planners and managers need to know what types of changes you think would help maintain or improve the quality of life in your community. For each of the following items, would you like to see an increase, a decrease, or no change from current levels?

\section{Potential Change}

a. Minerals and energy mining in the county should. . .

b. Levels of tourism and outdoor recreation should. . .

c. The numbers of new people moving into the community should. . .

$\begin{array}{lllllllll}\text { d. The amount of wilderness in Southeastern } & 1 & 2 & 3 & 4 & 5 & 6 & 7\end{array}$ Utah should. . .

e. Zoning to protect agricultural lands and open space should. .

f. Road access to hunting and fishing areas should. . .

g. Parks and open space in the community should. . .

h. Attractions and services to encourage visitors to stop over rather than just drive through the community, should. ...

I. Timber harvesting in the forests of the county should. ...

j. Grazing on the public lands in the county $\quad \begin{array}{llllllll}1 & 2 & 3 & 4 & 5 & 6 & 7\end{array}$ should. ...
k. Tourism and recreation jobs for local residents should. . .

$\begin{array}{lllllll}1 & 2 & 3 & 4 & 5 & 6 & 7\end{array}$
1. Jobs in traditional county industries should. . $\begin{array}{llllllll}1 & 2 & 3 & 4 & 5 & 6 & 7\end{array}$

\section{To keep or improve Quality of Life:}

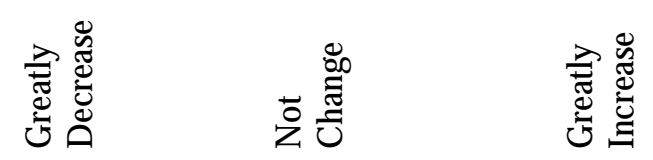

each item.

Circle the appropriate number, on the scale provided, for each item. 


\section{SPECIAL PLACES}

7. Please take a moment to think about two or three areas or places in Southeastern Utah that have a special personal meaning or importance to you. For each of those places you think of, please tell us the name and location, what things you do in each location, and the reasons that place has special meaning for you. (By "Southeastern Utah" we mean Carbon, Emery, Wayne, Grand, and San Juan Counties.)

\section{A. First Special Place}

Name and Location:

Things you do there:

Reasons this place has special meaning:

Did you take a photograph of this place? (Write number from the back of the photo)

Do you know the Landowner? (Please check and specify)

Private

County --->if so, $\square$ Park, or $\square$ other?

State --->if so, $\square$ Park, $\square$ School Trust land, $\square$ Wildlife Refuge, or $\square$ other?

Federal --->if so, $\square$ BLM, $\square$ Forest Service, $\square$ Park Service, or $\square$ Fish \& Wildlife Service?

\section{B. Second Special Place}

Name and Location:

Things you do there:

Reasons this place has special meaning:

Did you take a photograph of this place? (Write number from the back of the photo)

Do you know the Landowner? (Please check and specify)

$\square$ Private

County --->if so, $\square$ Park, or $\square$ other?

State --->if so, $\square$ Park, $\square$ School Trust land, $\square$ Wildlife Refuge, or $\square$ other?

$\square$ Federal --->if so, $\square$ BLM, $\square$ Forest Service, $\square$ Park Service, or $\square$ Fish \& Wildlife Service?

\section{Other Special Places}

If you have more "special places", please record them on a separate piece of paper. 
17. Are you currently employed? $\square$ Salary / wage earner $\square$ Self-employed $\square$ Retired

$\square$ Homemaker $\square$ Student $\quad \square$ Unemployed

18. What is your usual occupation? Title:

Kind of Work:

19. Are you a permanent, year-round resident of Utah?

$\square$ YES --->if yes, for how long? ___ years

$\square$ NO ---> if no, are you: $\square$ a resident most of the year

a resident 6 months or less per year

$\square$ a visitor

Please use the space below and on the following page

for any further comments you would like to add.

\section{Additional Comments}

Thank you for your help.

Please place this survey in the envelope provided and mail it in. 


\title{
Appendix C:
}

\section{The Big Picture}

\author{
Quality-of-life Data \\ from the Camera Exercise
}

\section{San Rafael Swell}

The drive through this gorge is beautiful, especially through the colored rock area.

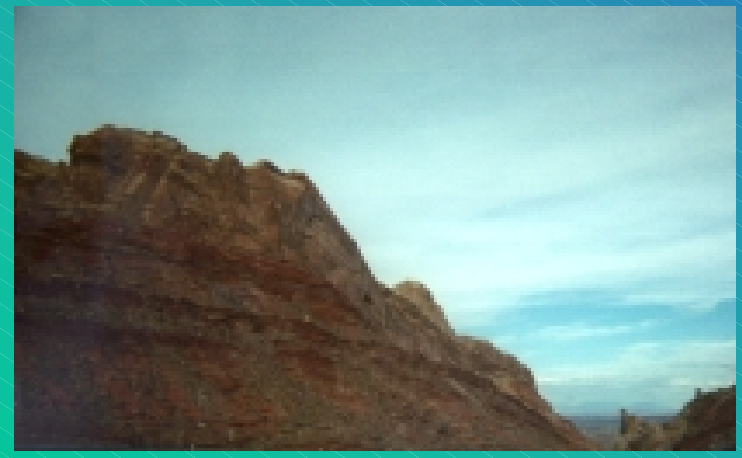

I enjoy the wonders of the desert; one side would like it closed and another small majority abuses and disregards God's creations. It would be nice if we could share and take care of the natural resources there.

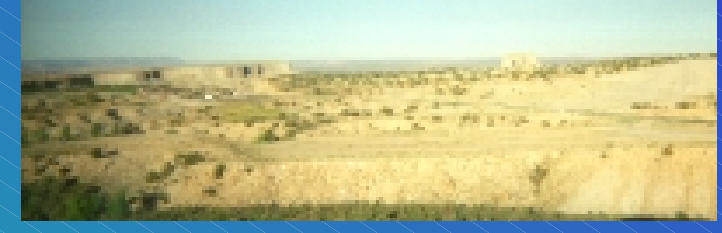

This is beautiful country we live in. It is hard to believe that in 20 minutes, one could drive there and see window rock, the little grand canyon and be on Highway 78 .

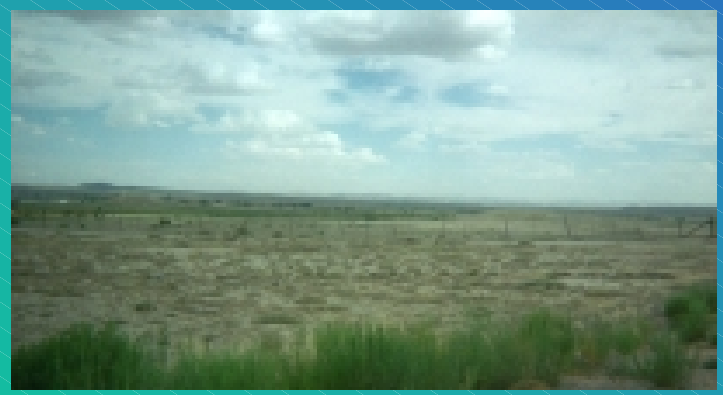




\begin{tabular}{|c|c|c|c|c|c|c|}
\hline \multicolumn{7}{|c|}{ Table C-1. Photographed Quality-of-Life Variables - by County } \\
\hline Variable & Total $n(\%)$ & Carbon $n(\%)$ & Emery $n(\%)$ & Grand $n(\%)$ & San Juan $n(\%)$ & Wayne $n(\%)$ \\
\hline PHOTO FEATURE: & 1,539 & 353 & 317 & 324 & 342 & 203 \\
\hline Community aesthetics & $195(12.7)$ & $32(9.0)$ & $34(10.7)$ & $58(17.9)$ & $36(10.5)$ & $35(17.2)$ \\
\hline Landscape vistas & $187(12.1)$ & $33(9.3)$ & $49(15.5)$ & $39(12.0)$ & $31(9.1)$ & $35(17.2)$ \\
\hline Public buildings/facilities & $185(12.0)$ & $52(14.7)$ & $24(7.6)$ & $39(12.0)$ & $59(17.3)$ & $11(5.4)$ \\
\hline Businesses open & $120(7.8)$ & $26(7.3)$ & $18(5.7)$ & $35(10.8)$ & $24(7.0)$ & $17(8.4)$ \\
\hline Parks \& open space & $112(7.3)$ & $29(8.2)$ & $25(7.9)$ & $34(10.5)$ & $18(5.3)$ & $6(3.0)$ \\
\hline Cultural & $91(5.9)$ & $32(9.0)$ & $10(3.2)$ & $13(4.0)$ & $27(7.9)$ & $9(4.4)$ \\
\hline Water & $90(5.8)$ & $17(4.8)$ & $35(11.0)$ & $13(4.0)$ & $20(5.8)$ & $5(2.5)$ \\
\hline Streets \& traffic & $83(5.4)$ & $32(9.0)$ & $22(6.9)$ & $8(2.5)$ & $16(4.7)$ & $5(2.5)$ \\
\hline Agriculture/ranching & $70(4.5)$ & $14(4.0)$ & $10(3.2)$ & $4(1.2)$ & $27(7.9)$ & $15(7.4)$ \\
\hline Recreation (out of town) & $55(3.6)$ & $7(2.0)$ & $15(4.7)$ & $16(4.9)$ & $10(2.9)$ & $7(3.4)$ \\
\hline Churches & $49(3.2)$ & $13(3.7)$ & $9(2.8)$ & $5(1.5)$ & $15(4.4)$ & $7(3.4)$ \\
\hline People & $48(3.1)$ & $13(3.7)$ & $7(2.2)$ & $10(3.1)$ & $10(2.9)$ & $8(3.9)$ \\
\hline Recreation (in town) & $46(3.0)$ & $17(4.8)$ & $5(1.6)$ & $11(3.4)$ & $8(2.3)$ & $5(2.5)$ \\
\hline Industries & $35(2.3)$ & $9(2.5)$ & $16(5.0)$ & $4(1.2)$ & $6(1.8)$ & $0(0)$ \\
\hline Animals in town & $30(1.9)$ & $5(1.4)$ & $9(2.8)$ & $0(0)$ & $8(2.3)$ & $8(3.9)$ \\
\hline Events & $25(1.6)$ & $2(0.6)$ & $7(2.2)$ & $10(3.1)$ & $5(1.5)$ & $1(0.5)$ \\
\hline Vegetation & $24(1.6)$ & $1(0.3)$ & $4(1.3)$ & $6(1.9)$ & $2(0.6)$ & $11(5.4)$ \\
\hline Human impacts (out town) & $19(1.2)$ & $2(0.6)$ & $5(1.6)$ & $3(0.9)$ & $1(0.3)$ & $8(3.9)$ \\
\hline Human impacts (in town) & $17(1.1)$ & $3(0.8)$ & $3(0.9)$ & $6(1.9)$ & $2(0.6)$ & $3(1.5)$ \\
\hline Resources & $15(1.0)$ & $4(1.1)$ & $5(1.6)$ & $5(1.5)$ & $0(0)$ & $1(0.5)$ \\
\hline Commerce/signs & $12(0.8)$ & $7(2.0)$ & $1(0.3)$ & $0(0)$ & $2(0.6)$ & $2(1.0)$ \\
\hline Wildlife & $11(0.7)$ & $0(0)$ & $2(0.6)$ & $2(0.6)$ & $5(1.5)$ & $2(1.0)$ \\
\hline Government & $7(0.5)$ & $1(0.3)$ & $0(0)$ & $2(0.6)$ & $3(0.9)$ & $1(0.5)$ \\
\hline Businesses closed & $7(0.5)$ & $2(0.6)$ & $2(0.6)$ & $1(0.3)$ & $1(0.3)$ & $1(0.5)$ \\
\hline Clubs & $6(0.4)$ & $0(0)$ & $0(0)$ & $0(0)$ & $6(1.8)$ & $0(0)$ \\
\hline PHOTO LOCATION: & 1,528 & 347 & 316 & 324 & 340 & 201 \\
\hline In town & $871(57.0)$ & $242(69.7)$ & $148(46.8)$ & $201(62.0)$ & $183(53.8)$ & $97(48.3)$ \\
\hline Out of town & $657(43.0)$ & $105(30.3)$ & $168(53.2)$ & $123(38.0)$ & $157(46.2)$ & $104(51.7)$ \\
\hline РНОTO ЕFFЕСТ: & 1,475 & 335 & 308 & 312 & 338 & 182 \\
\hline Positive & $1,146(66.3)$ & $262(78.2)$ & $239(77.6)$ & $220(70.5)$ & $287(84.9)$ & $138(75.8)$ \\
\hline Negative & $283(16.4)$ & $63(18.8)$ & $57(18.5)$ & $88(28.2)$ & $42(12.4)$ & $33(18.1)$ \\
\hline Both & $46(2.7)$ & $10(3.0)$ & $12(3.9)$ & $4(1.3)$ & $9(2.7)$ & $11(6.0)$ \\
\hline
\end{tabular}




\begin{tabular}{|c|c|c|c|c|}
\hline \multicolumn{5}{|c|}{$\begin{array}{c}\text { Table C-2. Photograph Variables by the Effect on Quality-of-life } \\
\text { (positive, negative, both) }\end{array}$} \\
\hline Variable & Total $n(\%)$ & Positive $n(\%)$ & Negative $n(\%)$ & Both $n(\%)$ \\
\hline PHOTO FEATURE: & 1,475 & 1,146 & 283 & 46 \\
\hline Public buildings/facilities & $182(12.3)$ & $156(85.7)$ & $21(11.5)$ & $5(2.7)$ \\
\hline Community aesthetics & $177(12.0)$ & $94(53.1)$ & 79 (44.6) & $4(2.3)$ \\
\hline Landscape vistas & 171 (11.6) & $164(95.9)$ & $6(3.5)$ & $1(0.6)$ \\
\hline Businesses open & $116(7.9)$ & $74(63.8)$ & $34(29.3)$ & $8(6.9)$ \\
\hline Parks \& open space & $108(7.3)$ & $102(94.4)$ & $3(2.8)$ & $3(2.8)$ \\
\hline Cultural & $91(6.2)$ & 88 (96.7) & $2(2.2)$ & $1(1.1)$ \\
\hline Water & $86(5.8)$ & $72(83.7)$ & $10(11.6)$ & $4(4.7)$ \\
\hline Streets \& traffic & $83(5.6)$ & $38(45.8)$ & $40(48.2)$ & $5(6.0)$ \\
\hline Agriculture/ranching & $70(4.7)$ & $66(94.3)$ & $4(5.7)$ & $0(0)$ \\
\hline Recreation (out of town) & $53(3.6)$ & $41(77.4)$ & $6(11.3)$ & $6(11.3)$ \\
\hline Churches & $46(3.1)$ & $45(97.8)$ & $0(0)$ & $1(2.2)$ \\
\hline Recreation (in town) & $45(3.1)$ & $41(91.1)$ & $2(4.4)$ & $2(4.4)$ \\
\hline People & $44(3.0)$ & $42(95.5)$ & $2(4.5)$ & $0(0)$ \\
\hline Industries & $34(2.3)$ & $21(61.8)$ & $10(29.4)$ & $3(8.8)$ \\
\hline Animals in town & $29(2.0)$ & $24(82.8)$ & $5(17.2)$ & $0(0)$ \\
\hline Events & $25(1.7)$ & $25(100)$ & $0(0)$ & $0(0)$ \\
\hline Vegetation & $23(1.6)$ & $18(78.3)$ & $5(21.7)$ & $0(0)$ \\
\hline Human impacts (out town) & $19(1.3)$ & $0(0)$ & $19(100.0)$ & $0(0)$ \\
\hline Human impacts (in town) & $17(1.2)$ & $0(0)$ & $17(100.0)$ & $0(0)$ \\
\hline Resources & $13(0.9)$ & $6(46.2)$ & $6(46.2)$ & $1(7.7)$ \\
\hline Wildlife & $11(0.7)$ & $10(90.9)$ & $1(9.1)$ & $0(0)$ \\
\hline Commerce/signs & $11(0.7)$ & $7(63.6)$ & $4(36.4)$ & $0(0)$ \\
\hline Government & $7(0.5)$ & $6(85.7)$ & $0(0)$ & $1(14.3)$ \\
\hline Businesses closed & $7(0.5)$ & $0(0)$ & $7(100.0)$ & $0(0)$ \\
\hline Clubs & $6(0.4)$ & $6(100)$ & $0(0)$ & $0(0)$ \\
\hline PHOTO LOCATION: & & & & \\
\hline $\begin{array}{l}\text { In town } \\
\text { Out of town }\end{array}$ & $\begin{array}{l}796(57.3) \\
593\end{array}$ & $\begin{array}{l}605(76.0) \\
476(80.3)\end{array}$ & $\begin{array}{l}165(20.7) \\
100(16.9)\end{array}$ & $\begin{array}{ll}26 & (3.3) \\
17 & (2.9)\end{array}$ \\
\hline
\end{tabular}




\begin{tabular}{|l|c|c|c|c|c|c|}
\hline \multicolumn{6}{|c|}{ Table C-3: Prominent Values Expressed in Quality-of-Life Explanations - by County } \\
\hline & $\begin{array}{c}\text { Total } \\
\text { SE Utah }\end{array}$ & $\begin{array}{c}\text { Carbon } \\
\text { County }\end{array}$ & $\begin{array}{c}\text { Emery } \\
\text { County }\end{array}$ & $\begin{array}{c}\text { Grand } \\
\text { County }\end{array}$ & $\begin{array}{c}\text { San Juan } \\
\text { County }\end{array}$ & $\begin{array}{c}\text { Wayne } \\
\text { County }\end{array}$ \\
\hline Children & $150(18.5)$ & $38(18.8)$ & $27(18.6)$ & $31(21.8)$ & $33(16.4)$ & $21(17.5)$ \\
\hline Beauty & $101(12.5)$ & $21(10.4)$ & $29(20.0)$ & $25(17.6)$ & $15(7.5)$ & $10(8.3)$ \\
\hline $\begin{array}{l}\text { Education \& } \\
\text { Learning }\end{array}$ & $87(10.7)$ & $27(13.4)$ & $11(7.6)$ & $13(9.2)$ & $26(12.9)$ & $10(8.3)$ \\
\hline Family & $80(10.0)$ & $20(9.9)$ & $9(6.2)$ & $8(5.6)$ & $22(11.0)$ & $21(17.5)$ \\
\hline Rural Character & $78(9.6)$ & $12(5.9)$ & $17(11.7)$ & $10(7.0)$ & $24(11.9)$ & $15(12.5)$ \\
\hline $\begin{array}{l}\text { Sense of } \\
\text { Community / } \\
\text { Neighborhood }\end{array}$ & $58(7.2)$ & $18(8.9)$ & $8(5.5)$ & $9(6.3)$ & $16(8.0)$ & $7(5.8)$ \\
\hline Religious Values & $53(6.5)$ & $11(5.5)$ & $9(6.2)$ & $6(4.2)$ & $18(9.0)$ & $9(7.5)$ \\
\hline Love & $51(6.3)$ & $12(5.9)$ & $5(3.5)$ & $12(8.5)$ & $12(6.0)$ & $10(8.3)$ \\
\hline $\begin{array}{l}\text { Friends and } \\
\text { Neighbors }\end{array}$ & $50(6.2)$ & $167.9)$ & $10(6.9)$ & $6(4.2)$ & $9(4.5)$ & $9(7.5)$ \\
\hline Peace and Quiet & $41(5.1)$ & $11(5.5)$ & $8(5.5)$ & $7(4.9)$ & $11(5.5)$ & $4(3.3)$ \\
\hline Nature / Natural & $32(4.0)$ & $6(3.0)$ & $8(5.5)$ & $8(5.6)$ & $8(4.0)$ & $2(1.7)$ \\
\hline Safe / Safety & $30(3.7)$ & $10(5.0)$ & $4(2.8)$ & $7(4.9)$ & $7(3.5)$ & $2(1.7)$ \\
\hline \begin{tabular}{l} 
TOTAL \\
\hline
\end{tabular} & 811 & 202 & 145 & 142 & 201 & 120 \\
\hline
\end{tabular}

\footnotetext{
${ }^{1}$ Number of occurrences of Value expression in statements accompanying photographs (column percents).
} 
Table C-4: Categorical Distribution of Environmental Values in Southeast Utah ${ }^{1}$

\begin{tabular}{|c|c|c|c|c|c|c|c|}
\hline & Aesthetic $^{2}$ & Recreational $^{3}$ & Natural $^{4}$ & Social $^{5}$ & Commercial $^{6}$ & Negative $^{7}$ & Historical $^{8}$ \\
\hline First Value $^{9}$ & $84(35.0)^{10}$ & $46(19.2)$ & $58(24.2)$ & $27(11.3)$ & $10(4.2)$ & $13(5.4)$ & $2(0.8)$ \\
\hline Second Value & $23(19.5)$ & $43(36.4)$ & $19(16.1)$ & $8(6.8)$ & $16(13.6)$ & $5(4.2)$ & $4(3.4)$ \\
\hline Third Value & $10(34.5)$ & $5(17.2)$ & $2(6.9)$ & $6(10.7)$ & $3(10.3)$ & $1(3.5)$ & $2(6.9)$ \\
\hline TOTAL & $117(30.2)$ & $94(24.3)$ & 79 (20.4) & $41(10.6)$ & $29(7.5)$ & $19(4.9)$ & $8(2.1)$ \\
\hline
\end{tabular}

Categories adapted from King (1966)

${ }^{2}$ Aesthetics include: Scenery, beauty, view; wonder, awesomeness, joy of living, uniqueness.

${ }^{3}$ Recreational Values for both consumptive and non-consumptive uses of the environment, e.g., hunting and watching wildlife.

${ }^{4}$ Natural Values include: Nature, natural experience; Restorative experience - away from everyday pressures, tranquility, peace \& quiet, escape; Clean, healthy environment - clean air, vegetation; Open spaces and "cleaned up."

${ }^{5}$ Social Values include: ...with family, ...with children, ...with friends; Bonding, sharing, value to community; Accessible-- close to + or closed off -.

${ }^{6}$ Commercial Values: Those related to making profit, including resource use, livelihood derived, tourism, private lands.

${ }^{7}$ Negative Values: Damage to environment, inappropriate use, pollution, destruction; Negative aspects of environment: Escape excessive heat, etc.

${ }^{8}$ Historical and Heritage Values; Includes pre-history.

${ }^{9}$ Position of value category statement, or clear dominance, within the full description of why quality-of-life subject was selected.

${ }^{10}$ Numbers in parentheses $=\underline{\text { Row }}$ percent: Percent distribution of First Value; Second Value, Third Value. 


\begin{tabular}{|c|c|c|c|c|c|}
\hline \multicolumn{6}{|c|}{ Table C-5: County Distribution of Environmental Values in Southeast Utah } \\
\hline Values $^{1}$ & $\begin{array}{l}\text { Carbon } \\
\text { County }\end{array}$ & $\begin{array}{l}\text { Emery } \\
\text { County }\end{array}$ & $\begin{array}{l}\text { Grand } \\
\text { County }\end{array}$ & $\begin{array}{c}\text { San Juan } \\
\text { County }\end{array}$ & $\begin{array}{l}\text { Wayne } \\
\text { County }\end{array}$ \\
\hline Aesthetics & $21(39 \%)^{2}$ & $35(29 \%)$ & $25(35 \%)$ & $23(23 \%)$ & $13(34 \%)$ \\
\hline Outdoor Recreation & $7(13 \%)$ & $38(31 \%)$ & $13(18 \%)$ & $26(25 \%)$ & $10(26 \%)$ \\
\hline Nature / Natural & $12(22 \%)$ & $23(19 \%)$ & $9(13 \%)$ & $32(31 \%)$ & $3(8 \%)$ \\
\hline Social & $4(7 \%)$ & $15(12 \%)$ & $6(8 \%)$ & $11(11 \%)$ & $5(13 \%)$ \\
\hline Commercial & $2(4 \%)$ & $7(6 \%)$ & $8(11 \%)$ & $6(6 \%)$ & $6(16 \%)$ \\
\hline Negative / Impacts & $5(9 \%)$ & $2(2 \%)$ & $11(15 \%)$ & - & $1(3 \%)$ \\
\hline Historical Heritage & $3(6 \%)$ & $1(1 \%)$ & - & $4(4 \%)$ & - \\
\hline TOTALS & 54 & 121 & 72 & 102 & 38 \\
\hline
\end{tabular}

${ }^{1}$ Refer to Table C-4 for Value (row) Totals.

$2(\%)=$ column percent: Proportion of values expressed within that County. 


\begin{tabular}{|c|c|c|c|c|}
\hline \multicolumn{5}{|c|}{ Table C-6: PINs: Locations Perceptually Important to Local Residents' Quality-of-Life 1} \\
\hline Carbon County & Emery County & Grand County & San Juan County & Wayne County \\
\hline Museum \& Peace Park 12 & Joe's Valley Reservoir & La Sal Mountains & Blue (Abajo) Mountain & Boulder Mountain \\
\hline College of Eastern Utah 11 & Emery High School & Arches National Park & Recapture Reservoir & Capitol Reef N P \\
\hline Helper Riverside Park & San Rafael Swell & Colorado River, Moab & San Juan Hospital & Wayne County Pool \\
\hline $\begin{array}{l}\text { Western Mining \& Railroad } \\
\text { Museum } 7\end{array}$ & $\begin{array}{l}\text { Millsite Golf Course } \\
\text { \& Spillway }\end{array}$ & Old City Park, Moab & San Juan County Library & LDS Church, Loa \\
\hline Scofield Reservoir & Millsite Reservoir Park & Rim Cliffs - Moab & Canyonlands N P & Wayne High School \\
\hline Park and Wave Pool & 5 Huntington Lake Park & Moab Golf Club & Blanding Medical Ctr & Aspen Academy, Loa \\
\hline Skyline Drive & Huntington Canyon & Matheson Wetlands Pres & Lloyd's Lake & Ant Hill \\
\hline Price City Park Playgrd. 4 & Hunter Power Plant & Rotary Park & Lake Powell, Bullfrog & Wayne Middle School \\
\hline Castle View Hospital & Castle Valley Pageant Site & Mill Creek Walkway & $\begin{array}{l}\text { Manti-LaSal NF \& } \\
\text { Dalton Springs CG }\end{array}$ & Junkyard, Bicknell \\
\hline Main Street, Helper & Huntington Power Plant & Moab Valley & Circle Park, Blanding & Turner Park, Loa \\
\hline Willow Creek Coal Mine 4 & Horne Mountain & Slick Rock / Sand Flats & Monticello Ball Field & Thousand Lake Mountain 3 \\
\hline Pioneer Park & S. Huntington Trailer Pk & Grand County H. S. & Monticello H. S. & Mormon Pioneer Trek \\
\hline \multirow[t]{2}{*}{9 Mile Canyon } & Electric Lake & Spanish Trail Arena & Pioneer Park, Monticello & \\
\hline & Museum of San Rafael & Allen Memorial Hospital & Monticello Pool & \\
\hline & & Star Hall & $\begin{array}{l}\text { Blue Mountain } \\
\text { Golf Course }\end{array}$ & \\
\hline & & Land Fill \& Recycling Ctr. 4 & $\begin{array}{l}\text { Monticello Primary } \\
\text { School }\end{array}$ & \\
\hline & & Water Park & Dinosaur Museum & \\
\hline & & Grand County Library & $\begin{array}{l}\text { Edge of Cedars Park / } \\
\text { Museum }\end{array}$ & \\
\hline & & $\begin{array}{l}\text { Information Ctr., } \\
\text { Moab }\end{array}$ & Four Corners Cultural Ctr. 3 & \\
\hline & & Ball Field & Blanding Airport & \\
\hline & & Auto Junk Yard & Bank - Blanding & \\
\hline & & & LDS Church, Blanding & \\
\hline & & & Bears Ears Mtn. & \\
\hline
\end{tabular}

${ }^{1}$ Locations are listed in descending order, numbers in lower right-hand corner $=$ number of people selecting this location. 


\section{Appendix D:}

\section{The Follow-Up}

\section{Quality-of-life Data from the Follow-Up Survey}

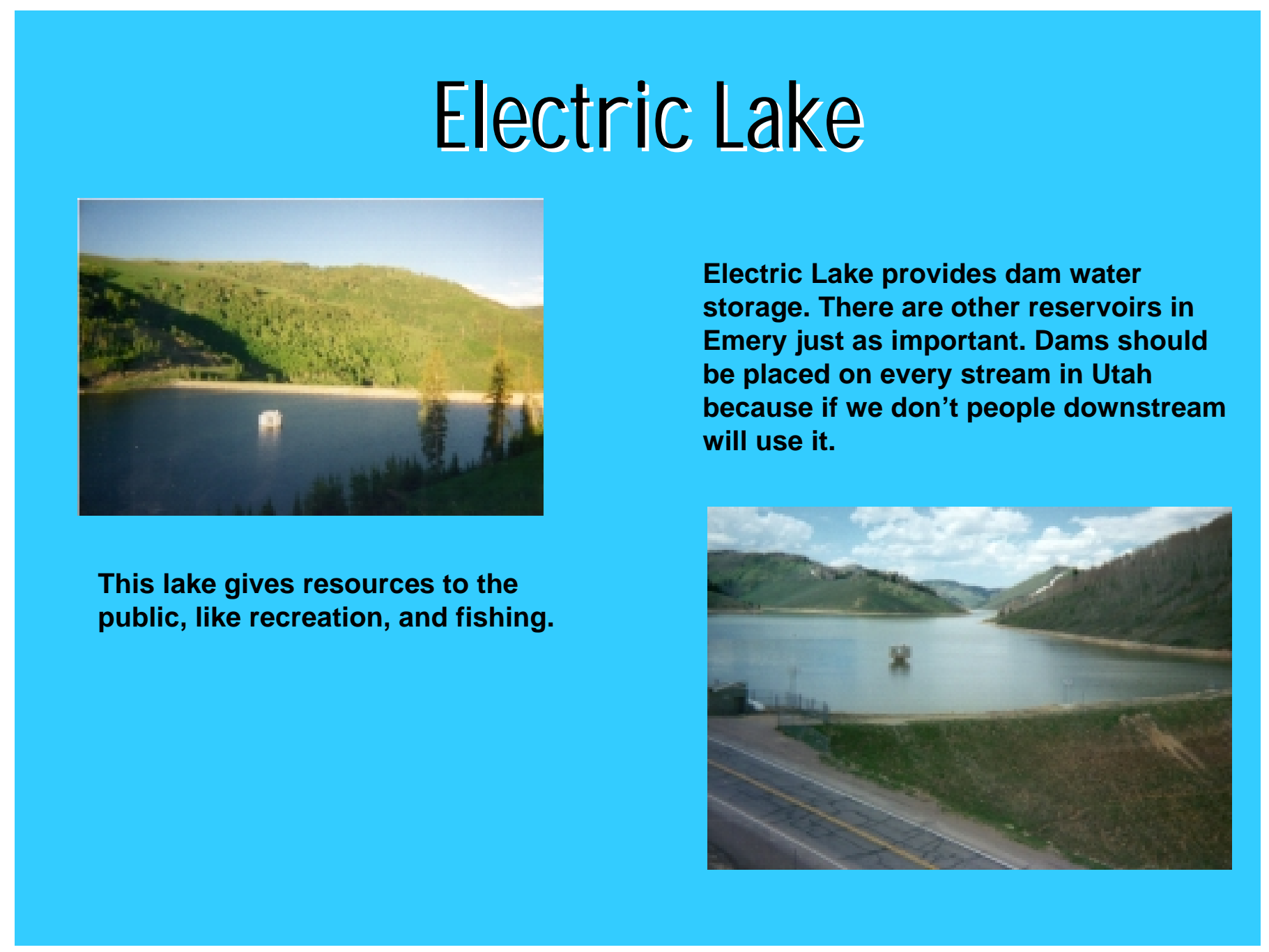




\begin{tabular}{|l|c|c|c|c|}
\hline \multicolumn{5}{|c|}{ Table D-1: “How satisfied are you with your community } \\
as a place to live?" \\
\hline \multicolumn{1}{|c|}{ County $^{1}$} & $n$ & Mean $^{2}$ & Range & SD \\
\hline Carbon & 18 & 5.6 & $3-7$ & 1.24 \\
Emery & 16 & 5.5 & $1-7$ & 1.46 \\
Grand & 21 & 5.6 & $3-7$ & 1.20 \\
San Juan & 19 & 5.8 & $2-7$ & 1.10 \\
Wayne & 11 & 5.9 & $5-7$ & .70 \\
\hline Total & 85 & 5.6 & $1-7$ & 1.17 \\
\hline
\end{tabular}

${ }^{1}$ Variables listed by counties in which sample communities are located: Carbon County: Price, Helper,

Emery County: Castledale, Huntington, Ferron, Clawson, Orangeville Grand County: Moab

San Juan County: Monticello, Blanding

Wayne County: Loa, Bicknell, Lyman, Teasdale, Torrey,

2 Means are based on a scale of $1=$ completely dissatisfied to $7=$ completely satisfied.

\begin{tabular}{|l|c|c|c|c|}
\hline \multicolumn{5}{|c|}{$\begin{array}{c}\text { Table D-2: “How important is the surrounding natural } \\
\text { environment to your quality of life?" }\end{array}$} \\
\hline \multicolumn{1}{|c|}{ County } & $n$ & Mean $^{1}$ & Range & SD \\
\hline Carbon & 18 & 6.2 & $5-7$ & .82 \\
Emery & 14 & 6.3 & $5-7$ & .84 \\
Grand & 20 & 6.4 & $3-7$ & 1.04 \\
San Juan & 19 & 6.4 & $5-7$ & .69 \\
Wayne & 11 & 6.5 & $5-7$ & .82 \\
\hline Total & 82 & 6.4 & $3-7$ & .84 \\
\hline
\end{tabular}

${ }^{1}$ Means are based on a scale of $1=$ not at all important to $7=$ extremely important. 


\begin{tabular}{|c|c|c|c|c|c|c|}
\hline \multicolumn{7}{|c|}{$\begin{array}{l}\text { Table D-3: "What is especially good about living in this community?" } \\
\text { ( by County) }\end{array}$} \\
\hline Reasons ${ }^{1}$ & $\begin{array}{c}\text { Total } \\
n=256 \\
n \quad(\%)\end{array}$ & $\begin{array}{l}\text { Carbon } \\
n=59 \\
n \quad(\%)\end{array}$ & $\begin{array}{l}\text { Emery } \\
n=48 \\
n \quad \%)\end{array}$ & $\begin{array}{l}\text { Grand } \\
n=61 \\
n(\%)\end{array}$ & $\begin{array}{l}\text { San Juan } \\
n=57 \\
n \quad(\%)\end{array}$ & $\begin{array}{l}\text { Wayne } \\
n=33 \\
n \quad \%)\end{array}$ \\
\hline $\begin{array}{l}\text { NATURAL/ENVIRONMENT: } \\
\text { Scenery/Beauty of area } \\
\text { Weather/Climate } \\
\text { Physical/Natural environment } \\
\text { Clean air/No pollution } \\
\text { Location/Closeness to natural environment } \\
\text { Outdoor recreation activities } \\
\text { Large outdoor areas/Open space }\end{array}$ & $\begin{array}{l}\frac{73}{17(6.6)} \\
14(5.5) \\
12(4.7) \\
11(4.3) \\
9(3.5) \\
8(3.1) \\
1(0.4)\end{array}$ & $\begin{array}{c}\frac{10(17.0)}{1} \\
- \\
1 \\
5 \\
3 \\
- \\
-\end{array}$ & $\begin{array}{l}\frac{10(20.8)}{1} \\
1 \\
4 \\
- \\
3 \\
- \\
1\end{array}$ & $\begin{array}{l}\frac{29(47.5)}{6} \\
9 \\
5 \\
1 \\
2 \\
6 \\
-\end{array}$ & $\begin{array}{l}\frac{11(19.3)}{3} \\
3 \\
- \\
3 \\
1 \\
1 \\
-\end{array}$ & $\begin{array}{c}\frac{12(36.4)}{6} \\
1 \\
2 \\
2 \\
- \\
1 \\
-\end{array}$ \\
\hline $\begin{array}{l}\text { COMMUNITY CHARACTER: }(23.4 \%) \\
\text { Small town atmosphere/rural character/size } \\
\text { No congestion } \\
\text { Peace and quiet } \\
\text { Locational Attributes } \\
\text { Sense of community/trustworthy people } \\
\text { Wonderful place to live }\end{array}$ & $\begin{array}{l}\frac{60}{29(11.3)} \\
14(5.5) \\
9(3.5) \\
4(1.6) \\
1(0.4) \\
1(0.4)\end{array}$ & $\begin{array}{c}\frac{14(23.7)}{8} \\
4 \\
1 \\
1 \\
- \\
-\end{array}$ & $\begin{array}{c}11(22.9) \\
3 \\
3 \\
3 \\
1 \\
- \\
1\end{array}$ & $\begin{array}{c}\frac{14(23.0)}{10} \\
3 \\
- \\
1 \\
- \\
-\end{array}$ & $\begin{array}{c}\frac{12(21.1)}{6} \\
2 \\
2 \\
1 \\
1 \\
-\end{array}$ & $\begin{array}{l}7(21.2) \\
2 \\
2 \\
3 \\
- \\
- \\
-\end{array}$ \\
\hline $\begin{array}{l}\text { PEOPLE/NEIGHBORHOOD: } \\
\text { Friendliness/Care of people } \\
\text { Social/People } \\
\text { Familiarity/Know everyone } \\
\text { Diversity of people } \\
\text { High standards/moral/traditional people }\end{array}$ & $\begin{array}{l}\frac{58}{31(12.1)} \\
19(7.4) \\
4(1.6) \\
3(1.2) \\
1(0.4)\end{array}$ & $\begin{array}{c}\frac{14(23.7)}{7} \\
5 \\
- \\
2 \\
-\end{array}$ & $\begin{array}{c}\frac{12(25.0)}{5} \\
4 \\
3 \\
- \\
-\end{array}$ & $\begin{array}{c}\frac{8(13.2)}{5} \\
2 \\
- \\
1 \\
-\end{array}$ & $\begin{array}{c}\frac{16(28.1)}{8} \\
6 \\
1 \\
- \\
1\end{array}$ & $\begin{array}{l}\frac{8(24.2)}{6} \\
2 \\
- \\
- \\
-\end{array}$ \\
\hline $\begin{array}{l}\text { OPPORTUNITIES: } \\
\text { Good schools } \\
\text { Variety of activities } \\
\text { Facilities / Services (incl. Senior) } \\
\text { Jobs/Work } \\
\text { Chapel/Church/Worship } \\
\text { Near university } \\
\text { Shopping stores }\end{array}$ & $\begin{array}{l}\frac{32}{10(3.9)} \\
5(2.0) \\
5(2.0) \\
3(1.2) \\
3(1.2) \\
2(0.8) \\
2(0.8)\end{array}$ & $\begin{array}{c}11(18.6) \\
2 \\
3 \\
2 \\
1 \\
2 \\
1 \\
-\end{array}$ & $\begin{array}{c}6(12.5) \\
4 \\
- \\
2 \\
- \\
- \\
- \\
-\end{array}$ & $\begin{array}{c}3(4.9) \\
- \\
- \\
- \\
2 \\
- \\
- \\
1\end{array}$ & $\begin{array}{c}8(14.0) \\
3 \\
1 \\
1 \\
- \\
1 \\
1 \\
1\end{array}$ & $\begin{array}{c}2(6.1) \\
1 \\
1 \\
- \\
- \\
- \\
- \\
-\end{array}$ \\
\hline $\begin{array}{l}\text { SAFETY: } \\
\text { Low levels of fear / crime } \\
\text { Crime / Safety } \\
\text { No gangs / Safe for kids }\end{array}$ & $\begin{array}{l}\frac{17}{10(3.9)} \\
3(1.2) \\
3(1.2)\end{array}$ & $\begin{array}{c}1(1.7) \\
1 \\
- \\
-\end{array}$ & $\begin{array}{c}7(14.6) \\
4 \\
1 \\
2\end{array}$ & $\begin{array}{c}1(1.6) \\
1 \\
- \\
-\end{array}$ & $\begin{array}{c}5(8.8) \\
3 \\
2 \\
-\end{array}$ & $\begin{array}{c}\frac{2(6.1)}{1} \\
- \\
1\end{array}$ \\
\hline $\begin{array}{l}\text { FAMILY: } \\
\text { Family/Family atmosphere } \\
\text { Good place to raise a family } \\
\text { Own our home }\end{array}$ & $\begin{array}{l}\frac{12}{7(2.7)} \\
4(1.6) \\
1(0.4)\end{array}$ & $\begin{array}{c}4(6.8) \\
2 \\
2 \\
-\end{array}$ & $\begin{array}{l}- \\
- \\
-\end{array}$ & $\begin{array}{c}6(9.8) \\
3 \\
2 \\
1\end{array}$ & $\begin{array}{c}\frac{2(3.5)}{2} \\
- \\
-\end{array}$ & $\begin{array}{l}- \\
- \\
-\end{array}$ \\
\hline $\begin{array}{l}\text { LIFESTYLE: } \\
\text { Freedom / Fewer limits } \\
\text { Pets } \\
\text { Slower Pace }\end{array}$ & $\begin{array}{l}\frac{4}{2(0.8)} \\
1(0.4) \\
1(0.4)\end{array}$ & $\frac{1(1.7)}{-}$ & $\begin{array}{c}2(4.2) \\
1 \\
- \\
1\end{array}$ & $\begin{array}{l}- \\
- \\
-\end{array}$ & $\begin{array}{c}\frac{1(1.8)}{1} \\
- \\
-\end{array}$ & $\begin{array}{l}- \\
- \\
-\end{array}$ \\
\hline
\end{tabular}

\footnotetext{
${ }^{1}$ Each respondent listed up to 3 reasons..
} 


\begin{tabular}{|c|c|c|c|c|c|c|}
\hline \multicolumn{7}{|c|}{$\begin{array}{l}\text { Table D-4: "How is your community } U N I Q U E \text {, } \\
\text { what distinguishes it from other communities?" }\end{array}$} \\
\hline Value & $\begin{array}{c}\text { Total } \\
n=78 \\
n \quad(\%)\end{array}$ & $\begin{array}{c}\text { Carbon } \\
n=19 \\
n \quad(\%)\end{array}$ & $\begin{array}{l}\text { Emery } \\
n=14 \\
n(\%)\end{array}$ & $\begin{array}{l}\text { Grand } \\
n=19 \\
n \quad(\%)\end{array}$ & $\begin{array}{c}\text { San Juan } \\
n=15 \\
n \quad(\%)\end{array}$ & $\begin{array}{l}\text { Wayne } \\
n=11 \\
n \quad \%)\end{array}$ \\
\hline NATURAL/ENVIRONMENT: $\quad(42.3 \%)$ & 33 & 4 & 7 & 12 & 6 & 4 \\
\hline Physical/Natural environment & $24(30.8)$ & $3(15.8)$ & $3(21.4)$ & 11(57.9) & $4(26.7)$ & $3(27.3)$ \\
\hline Location/Closeness to natural environment & $3(3.8)$ & - & $3(21.4)$ & - & - & - \\
\hline Dirt/Gardening spots & $2(2.6)$ & - & - & - & $2(13.3)$ & - \\
\hline Scenery/Beauty of area & $2(2.6)$ & - & - & $1(5.3)$ & - & $1(9.1)$ \\
\hline Large outdoor areas/Open space & $1(1.3)$ & - & $1(7.1)$ & - & - & - \\
\hline Outdoor recreation activities & $1(1.3)$ & $1(5.3)$ & - & - & - & - \\
\hline COMMUNITY CHARACTER: $\quad(19.2 \%)$ & 15 & 4 & 4 & 2 & 2 & 3 \\
\hline Small town atmosphere/rural character/size & $6(7.7)$ & $2(10.6)$ & $\overline{1(7.1)}$ & $1(5.3)$ & $\overline{1(6.7)}$ & $\overline{1(9.1)}$ \\
\hline No two houses look alike & $3(3.8)$ & $1(5.3)$ & $1(7.1)$ & $1(5.3)$ & - & - \\
\hline Sense of community/trustworthy people & $2(2.6)$ & - & - & - & $1(6.7)$ & $1(9.1)$ \\
\hline Clean town/Fixing up homes & $2(2.6)$ & - & $2(14.3)$ & - & - & - \\
\hline No formal block pattern for streets & $1(1.3)$ & - & - & - & - & $1(9.1)$ \\
\hline Older community & $1(1.3)$ & $1(5.3)$ & - & - & - & - \\
\hline PEOPLE/NEIGHBORHOOD: $\quad(14.1 \%)$ & 11 & 5 & 1 & 1 & 2 & 2 \\
\hline Diversity of people & $4(5.1)$ & $4(21.1)$ & - & - & - & - \\
\hline Familiarity/Know everyone & $2(2.6)$ & $1(5.3)$ & - & - & $1(6.7)$ & - \\
\hline People have own ideas/Politically unique & $2(2.6)$ & - & - & $1(5.3)$ & - & $1(9.1)$ \\
\hline Social/People & $1(1.3)$ & - & $1(7.1)$ & - & - & - \\
\hline Friendliness/Care of people & $1(1.3)$ & - & - & - & $1(6.7)$ & - \\
\hline High standards/moral/traditional people & $1(1.3)$ & - & - & - & - & $1(9.1)$ \\
\hline MISCELLANEOUS: & 5 & 1 & 1 & 1 & 2 & - \\
\hline No alcohol sold in town & $2(2.6)$ & - & - & - & $2(13.3)$ & - \\
\hline Tourism/Sprawl & $2(2.6)$ & $1(5.3)$ & - & $1(5.3)$ & - & - \\
\hline No fast food & $1(1.3)$ & - & $1(7.1)$ & - & - & - \\
\hline OPPORTUNITIES: & 4 & 3 & - & - & - & 1 \\
\hline Industry/Mining & $2(2.6)$ & $2(10.5)$ & - & - & - & - \\
\hline Chapel/Church/Worship & $1(1.3)$ & - & - & - & - & $1(9.1)$ \\
\hline Variety of activities & $1(1.3)$ & $1(5.3)$ & - & - & - & - \\
\hline LIFESTYLE: & 4 & - & - & 2 & 1 & 1 \\
\hline Patriotic & $1(1.3)$ & - & - & - & - & $1(9.1)$ \\
\hline Remoteness/Isolation & $3(3.8)$ & - & - & $2(10.5)$ & $1(6.7)$ & - \\
\hline NOTHING: & 4 & $1(5.3)$ & $1(7.1)$ & $1(5.3)$ & $1(6.7)$ & - \\
\hline SAFETY: & 2 & 1 & - & - & 1 & - \\
\hline Low levels of fear/crime & $\overline{1(1.3)}$ & $\overline{1(5.3)}$ & - & - & - & - \\
\hline No gangs & $1(1.3)$ & - & - & - & $1(6.7)$ & - \\
\hline
\end{tabular}




\begin{tabular}{|c|c|c|c|c|c|c|}
\hline \multicolumn{7}{|c|}{$\begin{array}{c}\text { Table D-5: Special Places Listed by Three or More Respondents } \\
\text { (Total and County Distribution) }\end{array}$} \\
\hline Special Places & $\begin{array}{c}\text { Total } \\
n=160 \\
n \quad(\%)\end{array}$ & $\begin{array}{c}\text { Carbon } \\
n=35 \\
n \quad(\%)\end{array}$ & $\begin{array}{l}\text { Emery } \\
n=29 \\
n \quad(\%)\end{array}$ & $\begin{array}{c}\text { Grand } \\
n=39 \\
n \quad(\%)\end{array}$ & $\begin{array}{c}\text { San Juan } \\
n=36 \\
n \quad(\%)\end{array}$ & $\begin{array}{l}\text { Wayne } \\
n=21 \\
n \quad(\%)\end{array}$ \\
\hline $\begin{array}{l}\text { Manti-La Sal National } \\
\text { Forest (Mountain/Roads) }\end{array}$ & $16(10.0)$ & $1(2.9)$ & $2(6.9)$ & $11(28.1)$ & $2(5 . .6)$ & - \\
\hline Arches National Park & $10(6.3)$ & $1(2.9)$ & - & $8(20.5)$ & $1(2.8)$ & - \\
\hline Blue Mountain & $10(6.3)$ & - & - & $1(2.6)$ & $9(25.0)$ & - \\
\hline San Rafael Swell & $8(5.0)$ & $4(11.4)$ & $4(13.8)$ & - & - & - \\
\hline $\begin{array}{l}\text { Skyline Drive / } \\
\text { Huntington Canyon }\end{array}$ & $7(4.4)$ & $5(14.3)$ & $2(6.9)$ & - & - & - \\
\hline Capital Reef National Park & $5(3.1)$ & - & - & - & - & $5(23.8)$ \\
\hline Joe's Valley / Reservoir & $4(2.5)$ & $1(2.9)$ & $3(10.3)$ & - & - & - \\
\hline Lake Powell / Bullfrog Hike & $4(2.5)$ & $1(2.9)$ & $1(3.5)$ & $1(2.6)$ & $1(2.8)$ & - \\
\hline $\begin{array}{l}\text { Scofield Reservoir / } \\
\text { Clear Creek }\end{array}$ & $4(2.5)$ & $4(11.4)$ & - & - & - & - \\
\hline $\begin{array}{l}\text { Nine Mile Canyon / } \\
\text { Pine Canyon }\end{array}$ & $4(2.5)$ & $3(8.6)$ & - & - & $1(2.8)$ & - \\
\hline Canyons and Desert & $4(2.5)$ & - & $2(6.9)$ & $1(2.6)$ & $1(2.8)$ & - \\
\hline Helper Parkway & $3(1.9)$ & $3(8.6)$ & - & - & - & - \\
\hline Canyonlands National Park & $3(1.9)$ & - & - & $1(2.6)$ & $2(5.6)$ & - \\
\hline Bluff, UT & $3(1.9)$ & - & - & $1(2.6)$ & $2(5.6)$ & - \\
\hline
\end{tabular}




\begin{tabular}{|c|c|c|c|c|c|c|}
\hline \multicolumn{7}{|c|}{$\begin{array}{c}\text { Table D-6: “Do you know who owns this land?" } \\
\text { For Special Places, By County }\end{array}$} \\
\hline Land Ownership & $\begin{array}{l}\text { Total } \\
n=191 \\
n \quad(\%)\end{array}$ & $\begin{array}{l}\text { Carbon } \\
n=40 \\
n \quad(\%)\end{array}$ & $\begin{array}{l}\text { Emery } \\
n=37 \\
n \quad(\%)\end{array}$ & $\begin{array}{l}\text { Grand } \\
n=41 \\
n \quad \%)\end{array}$ & $\begin{array}{l}\text { San Juan } \\
n=47 \\
n \quad(\%)\end{array}$ & $\begin{array}{l}\text { Wayne } \\
n=23 \\
n(\%)\end{array}$ \\
\hline $\begin{array}{l}\text { PRIVATE: } \quad(16.8 \%) \\
\text { Private }\end{array}$ & $32(16.8)$ & $9(22.5)$ & $6(16.2)$ & $6(14.6)$ & $8(17.0)$ & $3(13.0)$ \\
\hline $\begin{array}{l}\text { COUNTY: } \quad(10.5 \%) \\
\text { County park } \\
\text { Other county }\end{array}$ & $\begin{array}{l}17(8.9) \\
3(1.6)\end{array}$ & $\begin{array}{l}6(15.0) \\
2(5.0)\end{array}$ & $\begin{array}{c}4(10.8) \\
-\end{array}$ & $\begin{array}{c}4(9.8) \\
-\end{array}$ & $\begin{array}{l}2(4.3) \\
1(2.1)\end{array}$ & $\begin{array}{c}1(4.4) \\
-\end{array}$ \\
\hline $\begin{array}{l}\text { STATE: } \\
\text { State park } \\
\text { School trust }\end{array}$ & $\begin{array}{l}18(9.4) \\
5(2.6)\end{array}$ & $\begin{array}{c}5(12.5) \\
-\end{array}$ & $\begin{array}{c}5(13.5) \\
1(2.7)\end{array}$ & $\begin{array}{l}3(7.3) \\
2(4.9)\end{array}$ & $\begin{array}{l}3(6.4) \\
2(4.3)\end{array}$ & $\begin{array}{c}2(8.7) \\
-\end{array}$ \\
\hline $\begin{array}{l}\text { FEDERAL: }(49.7 \%) \\
\text { Forest Service } \\
\text { BLM } \\
\text { Park service } \\
\text { Fish \& Wildlife Service }\end{array}$ & $\begin{array}{c}36(18.9) \\
34(17.8) \\
23(12.0) \\
2(1.1)\end{array}$ & $\begin{array}{c}4(10.0) \\
7(17.5) \\
3(7.5) \\
-\end{array}$ & $\begin{array}{c}7(18.9) \\
8(21.6) \\
1(2.7) \\
-\end{array}$ & $\begin{array}{c}7(17.1) \\
5(12.2) \\
11(26.8) \\
1(2.4)\end{array}$ & $\begin{array}{c}13(27.7) \\
12(25.5) \\
4(8.5) \\
\quad-\end{array}$ & $\begin{array}{l}5(21.7) \\
4(17.4) \\
4(17.4) \\
1(4.4)\end{array}$ \\
\hline DON'T KNOW: $11.0 \%$ & $21(11.0)$ & $6(15.0)$ & $5(13.5)$ & $3(7.3)$ & $4(8.5)$ & $3(13.0)$ \\
\hline
\end{tabular}




\begin{tabular}{|c|c|c|c|c|c|c|}
\hline \multicolumn{7}{|c|}{ Table D-7: What Things do You Do in Your Special Place? (By county) } \\
\hline Activities & $\begin{array}{c}\text { Total } \\
n=327 \\
n \quad \%)\end{array}$ & $\begin{array}{l}\text { Carbon } \\
\mathrm{n}=64 \\
n \quad \%)\end{array}$ & $\begin{array}{l}\text { Emery } \\
n=71 \\
n \quad \%)\end{array}$ & $\begin{array}{l}\text { Grand } \\
n=75 \\
n \quad \%)\end{array}$ & $\begin{array}{c}\text { San Juan } \\
n=77 \\
n \quad(\%)\end{array}$ & $\begin{array}{l}\text { Wayne } \\
n=40 \\
n \quad \%)\end{array}$ \\
\hline $\begin{array}{l}\text { NON-MOTORIZED } \\
\text { RECREATION: }\end{array}$ & 141 & $\begin{array}{c}27 \\
(42.1)\end{array}$ & $\begin{array}{c}30 \\
(42.3)\end{array}$ & $\begin{array}{c}33 \\
(44.0)\end{array}$ & $\begin{array}{c}31 \\
(40.3)\end{array}$ & $\begin{array}{c}20 \\
(50.0)\end{array}$ \\
\hline Hike/Walk & 56 & 11 & 7 & 15 & 11 & 12 \\
\hline Camp & 35 & 6 & 13 & 7 & 7 & 2 \\
\hline Picnic & 19 & 3 & 5 & 2 & 8 & 1 \\
\hline Photography & 11 & 2 & 2 & 3 & 2 & 2 \\
\hline Personal uses/Play/Fun & 9 & 4 & - & 3 & - & 2 \\
\hline Swim & 6 & 1 & 2 & 1 & 1 & 1 \\
\hline Cookout & 3 & - & - & 1 & 2 & - \\
\hline Horseback ride & 2 & - & 1 & 1 & - & - \\
\hline $\begin{array}{l}\text { NON-COMMERCIAL } \\
\text { COLLECTION: }\end{array}$ & 70 & $\begin{array}{c}14 \\
(21.9) \\
\end{array}$ & $\begin{array}{c}18 \\
(25.4)\end{array}$ & $\begin{array}{c}14 \\
(18.7) \\
\end{array}$ & $\begin{array}{c}18 \\
(23.4)\end{array}$ & $\begin{array}{c}6 \\
(15.0)\end{array}$ \\
\hline Fish & 39 & 9 & 11 & 9 & 7 & 3 \\
\hline Hunt & 22 & 5 & 5 & 4 & 6 & 2 \\
\hline Collect firewood, $\mathrm{x}$-mas trees & 5 & - & - & 1 & 3 & 1 \\
\hline Collect/Prospect fossils, minerals, & 4 & - & 2 & - & 2 & - \\
\hline ENVIRONMENT: & 41 & $7(10.9)$ & $5 \quad(7.0)$ & $9(12.0)$ & $14(18.2)$ & $6(15.0)$ \\
\hline Scenery viewing/Sightseeing & 26 & 3 & 4 & $\frac{12.0}{7}$ & 8 & 4 \\
\hline Watch wildlife & 9 & 1 & 1 & 2 & 3 & 2 \\
\hline Environmental features/attributes & 2 & 1 & - & - & 1 & - \\
\hline Historical viewing/Petroglyphs & 4 & 2 & - & - & 2 & - \\
\hline MOTORIZED RECREATION: & 30 & $\underline{8(12.5)}$ & $\underline{11(15.5)}$ & $5 \quad(6.7)$ & $\underline{5}(6.5)$ & $1 \quad(2.5)$ \\
\hline Drive/Ride motorcycle & 13 & 3 & 6 & $\frac{10.1}{3}$ & $\frac{10}{1}$ & $\frac{-}{-127}$ \\
\hline Boat & 6 & 2 & 1 & 1 & 2 & - \\
\hline Four wheel & 6 & 2 & 1 & 1 & 1 & 1 \\
\hline Water-ski & 5 & 1 & 3 & . & 1 & - \\
\hline WORK/HOME RELATED: & 15 & $\underline{3 \quad(4.7)}$ & $\underline{3 \quad(4.2)}$ & $\underline{3 \quad(4.0)}$ & $\underline{4 \quad(5.2)}$ & $\underline{2(5.0)}$ \\
\hline Reside here & 9 & 3 & 2 & 1 & 2 & 1 \\
\hline Work/employed in the area & 5 & - & - & 2 & 2 & 1 \\
\hline Garden/Tend orchard & 1 & - & 1 & - & - & - \\
\hline PERSONAL: & 11 & $\underline{3 \quad(4.7)}$ & $1 \quad(1.4)$ & $4 \quad(5.3)$ & $\underline{2}(2.6)$ & $1 \quad(2.5)$ \\
\hline Relax/Contemplate & 8 & 2 & - & 3 & 2 & 1 \\
\hline Worship & 2 & 1 & 1 & - & - & - \\
\hline Escape/Get Away & 1 & & - & 1 & - & - \\
\hline COMMERCIAL COLLECTION: (2.5) & 8 & - & $3(4.2)$ & $1(1.6)$ & $2(2.6)$ & $\underline{2(5.0)}$ \\
\hline Graze livestock & 4 & - & 1 & 1 & 2 & - \\
\hline Economic/Consumptive uses/values & 2 & - & - & - & - & 2 \\
\hline Farm/Ranch & 2 & - & 2 & - & - & - \\
\hline FAMILY/FRIENDS: & 8 & $\underline{2}(3.1)$ & 0 & $4 \quad(5.3)$ & $\underline{1 \quad(1.3)}$ & $1(2.5)$ \\
\hline Family outings/reunions & 3 & 1 & - & 1 & - & 1 \\
\hline Family/Friends related factors & 5 & 1 & - & 3 & 1 & - \\
\hline MISCELLANEOUS: & 3 & - & - & $2(2.7)$ & - & $1(2.5)$ \\
\hline
\end{tabular}




\begin{tabular}{|c|c|c|c|c|c|c|}
\hline \multicolumn{7}{|c|}{ Table D-8: Reasons Special Places Have Special Meaning (By County) } \\
\hline Reasons & $\begin{array}{l}\text { Total } \\
n=211\end{array}$ & $\begin{array}{l}\text { Carbon } \\
n=43\end{array}$ & $\begin{array}{l}\text { Emery } \\
n=32\end{array}$ & $\begin{array}{l}\text { Grand } \\
n=50\end{array}$ & $\begin{array}{c}\text { San Juan } \\
n=55\end{array}$ & $\begin{array}{l}\text { Wayne } \\
n=31\end{array}$ \\
\hline ENVIRONMENT: $\quad(32.2 \%)$ & 68 & $\underline{11(25.6)}$ & $\underline{10(31.3)}$ & $\underline{17(34.0)}$ & $\underline{20(36.4)}$ & $\underline{10(32.3)}$ \\
\hline Scenery/Beauty & 30 & 5 & $\frac{1}{3}$ & 8 & $\frac{10}{7}$ & $\frac{1}{7}$ \\
\hline Serene/Solitude/Remote & 21 & 2 & 4 & 6 & 6 & 3 \\
\hline Environmental settings and features & 6 & 2 & - & 1 & 3 & - \\
\hline Wildlife & 2 & 1 & - & - & 1 & - \\
\hline Wilderness values/Diversity & 2 & 1 & - & - & 1 & - \\
\hline Open space & 3 & - & 2 & - & 1 & - \\
\hline Climate & 2 & - & 1 & 1 & - & - \\
\hline Clean/Pristine area & 1 & - & - & 1 & - & - \\
\hline Geological value & 1 & - & & - & 1 & - \\
\hline FAMILY/FRIENDS: & 57 & $13(30.2)$ & $9(28.1)$ & $13(26.0)$ & $14(25.5)$ & $\underline{8(25.8)}$ \\
\hline Family/Friends related factors & 36 & 9 & 4 & & 9 & 5 \\
\hline Memories & 8 & - & 2 & 9 & 3 & 1 \\
\hline Family activities/Reunions & 6 & 1 & 2 & 2 & 1 & 2 \\
\hline Family traditions/Heritage & 4 & 2 & - & - & 1 & - \\
\hline Been in our family forever & 3 & 1 & 1 & $\begin{array}{l}1 \\
1\end{array}$ & - & - \\
\hline FAMILIARITY/ACCESS: $\quad(10.4 \%)$ & 22 & $6(14.0)$ & $4(12.5)$ & $3(6.0)$ & $5(9.1)$ & $4(12.9)$ \\
\hline Access/Proximity/Convenience & 13 & $\overline{5}$ & 1 & 1 & 3 & 3 \\
\hline Frequent use/Spent a lot of time there & 6 & 1 & 2 & 2 & - & 1 \\
\hline Familiarity/Comfortable/This is home & 3 & - & 1 & - & 2 & - \\
\hline RECREATION: & 17 & $5(11.6)$ & $3(9.4)$ & $3(6.0)$ & $2(3.6)$ & $4(12.9)$ \\
\hline General recreation & 6 & - & 2 & 1 & 1 & 2 \\
\hline Fishing & 4 & 2 & 1 & - & - & 1 \\
\hline Personal uses/Play/Fun & 4 & 1 & - & 2 & 1 & - \\
\hline Hunting & 3 & 2 & - & - & - & 1 \\
\hline ECONOMIC/CONSUMPTIVE: $\quad(8.1 \%)$ & 17 & $4(9.3)$ & $\underline{2(6.3)}$ & $4(8.0)$ & $6(10.9)$ & $1(3.2)$ \\
\hline Land ownership/Management factors & 10 & 3 & 1 & 2 & 3 & 1 \\
\hline Graze livestock & 2 & - & 1 & - & 1 & - \\
\hline Employed in area/Livelihood dependent & 5 & 1 & - & 2 & 2 & - \\
\hline PERSONAL/EMOTIONAL: & 17 & $1(2.3)$ & $4(12.5)$ & $6(12.0)$ & $6(10.9)$ & \\
\hline Get away/Escape & 8 & - & 2 & 2 & 4 & - \\
\hline Relaxation & 4 & 1 & - & 1 & 2 & - \\
\hline Mystery and related/Unique & 4 & - & 1 & 3 & - & - \\
\hline Symbolic/Spiritual & 1 & - & 1 & - & - & - \\
\hline MISCELLANEOUS: & 12 & $3(7.0)$ & $2(6.3)$ & $3(6.0)$ & $2(3.6)$ & $\underline{2(6.5)}$ \\
\hline Freedom to camp, etc. & 4 & - & 1 & 2 & 1 & - \\
\hline Historical values & 5 & 3 & 1 & - & 1 & - \\
\hline Important for at-risk programs & 1 & - & - & - & - & 1 \\
\hline Love animals/Sanctuary & 1 & - & - & 1 & - & - \\
\hline Sense of ownership & 1 & - & - & - & - & 1 \\
\hline
\end{tabular}


Table D-9: Changes that would improve Quality-of-Life (by County)

\begin{tabular}{|l|c|c|c|c|c|c|}
\hline \multicolumn{1}{|c|}{ Changes in: ${ }^{1}$} & Total & Carbon & Emery & Grand & San Juan & Wayne \\
\hline $\begin{array}{l}\text { Jobs in traditional county } \\
\text { industries }\end{array}$ & $5.4^{2}$ & 5.8 & 5.6 & 5.1 & 5.3 & 5.2 \\
\hline $\begin{array}{l}\text { Attractions and services to } \\
\text { encourage visitors to stop } \\
\text { over rather than just drive } \\
\text { through the community }\end{array}$ & 5.2 & 5.9 & 5.4 & 4.5 & 5.2 & 4.8 \\
\hline $\begin{array}{l}\text { Tourism and recreation jobs } \\
\text { for local residents }\end{array}$ & 5.0 & 5.6 & 5.1 & 4.5 & 4.9 & 5.2 \\
\hline $\begin{array}{l}\text { Minerals and energy mining } \\
\text { in the county }\end{array}$ & 5.0 & 5.1 & 5.0 & 4.5 & 5.5 & 4.7 \\
\hline $\begin{array}{l}\text { Zoning to protect agricultural } \\
\text { lands and open space }\end{array}$ & 4.8 & 5.0 & 4.8 & 5.1 & 4.8 & 4.5 \\
\hline $\begin{array}{l}\text { Parks and open space in the } \\
\text { community }\end{array}$ & 4.8 & 5.2 & 4.8 & 5.1 & 4.5 & 3.9 \\
\hline $\begin{array}{l}\text { Levels of tourism and } \\
\text { outdoor recreation }\end{array}$ & 4.8 & 5.1 & 5.3 & 4.1 & 4.8 & 4.7 \\
\hline $\begin{array}{l}\text { Road access to hunting and } \\
\text { fishing areas }\end{array}$ & 4.6 & 4.8 & 4.6 & 4.0 & 5.1 & 4.5 \\
\hline $\begin{array}{l}\text { Numbers of new people } \\
\text { moving into the community }\end{array}$ & 4.3 & 4.2 & 4.4 & 4.0 & 5.1 & 3.7 \\
\hline $\begin{array}{l}\text { Grazing on public lands in } \\
\text { the county }\end{array}$ & 4.4 & 4.4 & 4.3 & 3.7 & 5.1 & 4.8 \\
\hline $\begin{array}{l}\text { Timber harvesting in the } \\
\text { forests of the county }\end{array}$ & 4.2 & 4.0 & 4.1 & 3.5 & 4.8 & 4.6 \\
\hline $\begin{array}{l}\text { Amount of wilderness in } \\
\text { Southeastern Utah }\end{array}$ & 3.2 & 4.3 & 2.3 & 3.9 & 2.4 & 3.0 \\
\hline
\end{tabular}

${ }^{1}$ Change scale: 1 = Greatly Decrease, 4 = No Change, 7 = Greatly Increase - to improve quality of life.

2 Mean of group responses. 
Figure D-1a: Change to Improve Quality of Life

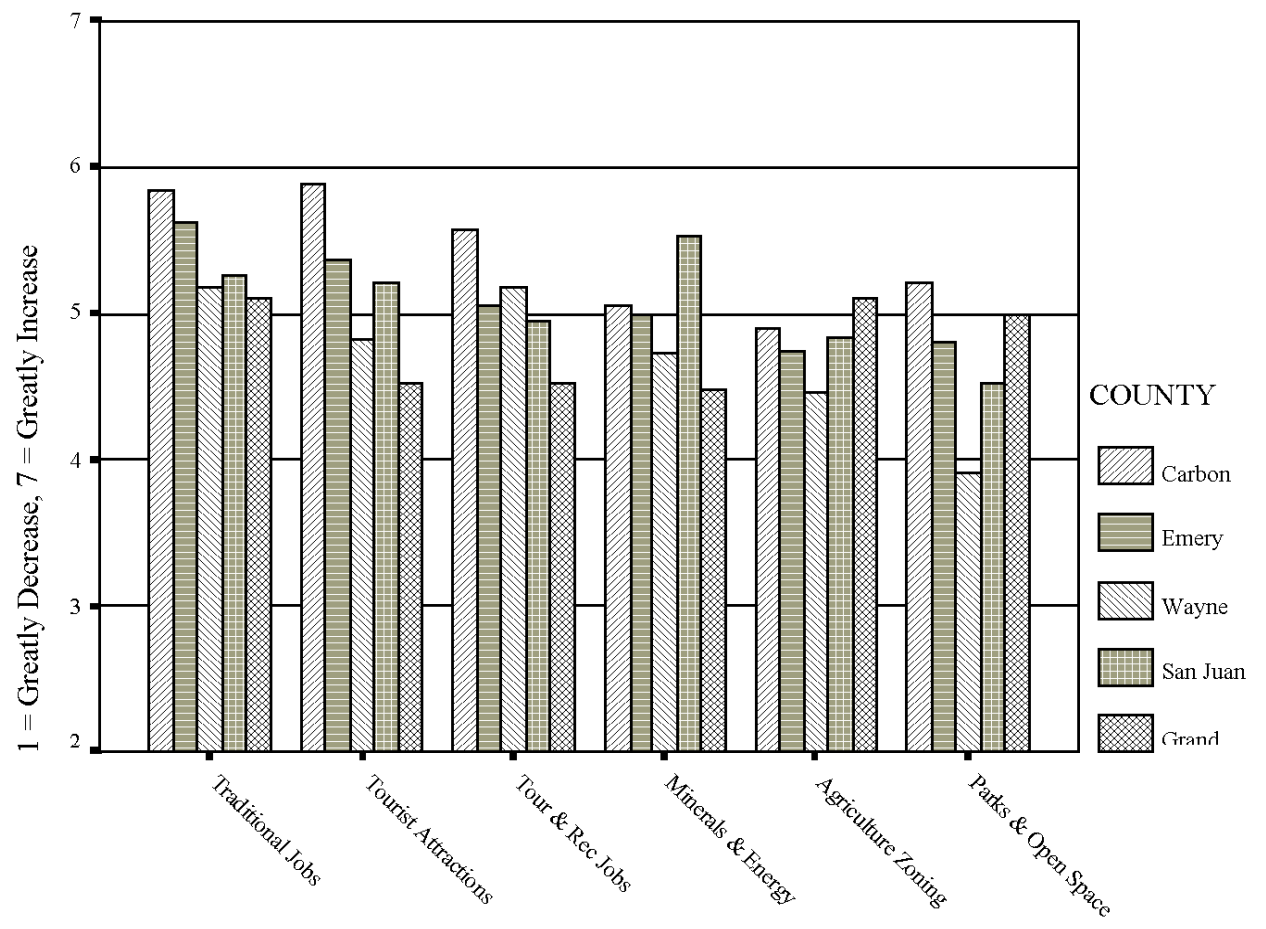

Figure D-1b: Change to Improve Quality of Life

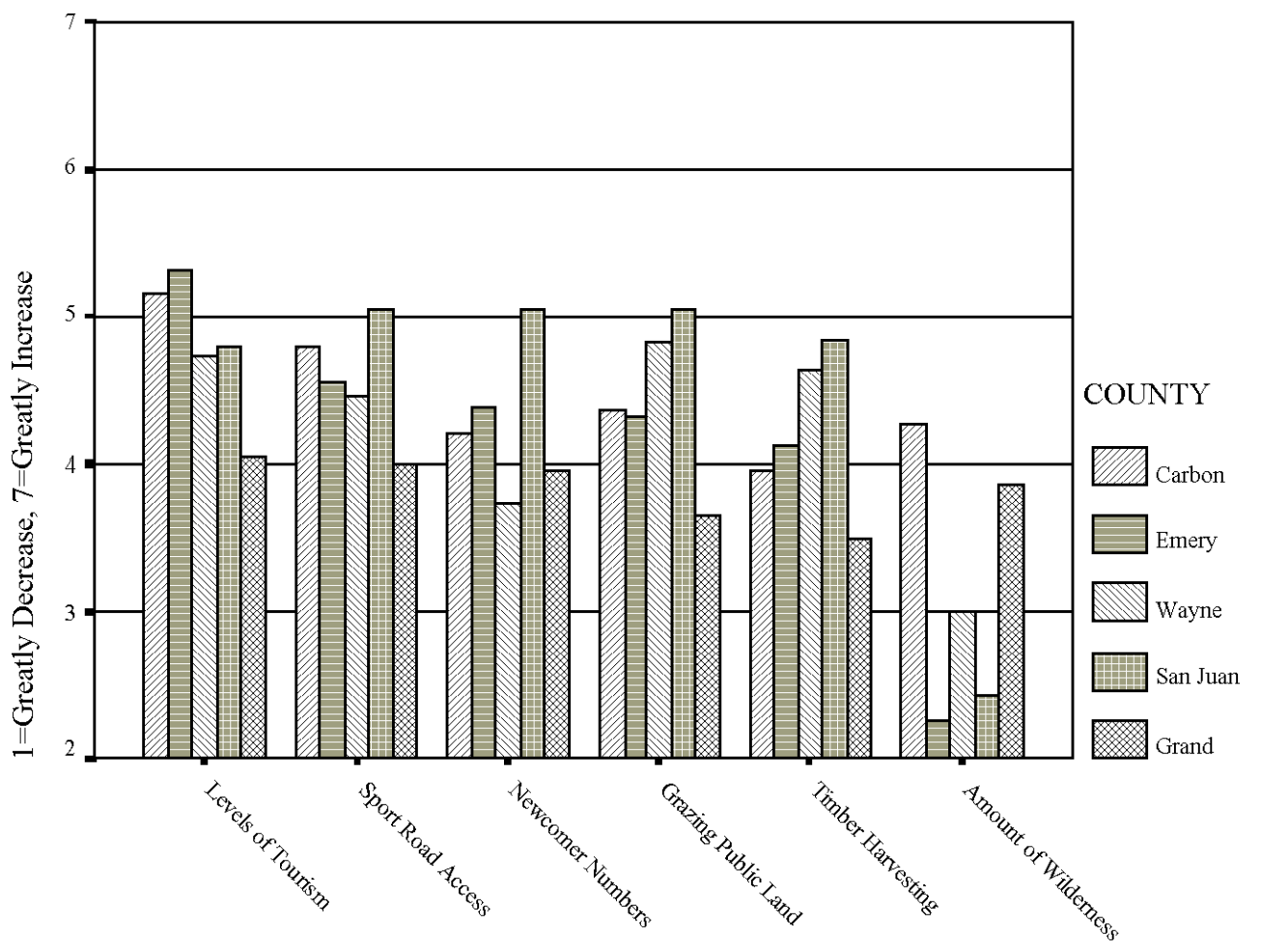




\begin{tabular}{|c|c|c|c|c|c|c|}
\hline \multicolumn{7}{|c|}{ Table D-10: Follow-up Survey Demographic Variables (by County) } \\
\hline Variable & $\begin{array}{l}\text { Total } \\
n(\%)\end{array}$ & $\begin{array}{l}\text { Carbon } \\
n(\%)\end{array}$ & $\begin{array}{l}\text { Emery } \\
n \quad(\%)\end{array}$ & $\begin{array}{l}\text { Grand } \\
n(\%)\end{array}$ & $\begin{array}{c}\text { San Juan } \\
n(\%)\end{array}$ & $\begin{array}{l}\text { Wayne } \\
n(\%)\end{array}$ \\
\hline $\begin{array}{l}\text { GENDER: } \\
\text { Male } \\
\text { Female }\end{array}$ & $\begin{array}{l}35(42.2) \\
48(57.8)\end{array}$ & $\begin{array}{c}9(47.4) \\
10(52.6)\end{array}$ & $\begin{array}{l}6(42.9) \\
8(57.1)\end{array}$ & $\begin{array}{c}7(33.3) \\
14(66.7)\end{array}$ & $\begin{array}{c}11(57.9) \\
8(42.1)\end{array}$ & $\begin{array}{l}2(20.0) \\
8(80.0)\end{array}$ \\
\hline $\begin{array}{l}\text { OCCUPATION: } \\
\text { Managerial/Professional } \\
\text { Tech/Sale/Admin. } \\
\text { Service } \\
\text { Farm/Forest/Fish } \\
\text { Precision/Craft/Repair } \\
\text { Operator/Laborer } \\
\text { Student }\end{array}$ & $\begin{array}{c}29(36.7) \\
10(12.7) \\
25(31.7) \\
3(3.8) \\
2(2.5) \\
8(10.2) \\
2(2.5)\end{array}$ & $\begin{array}{c}5(27.8) \\
4(22.2) \\
4(22.2) \\
- \\
- \\
3(16.7) \\
2(11.1)\end{array}$ & $\begin{array}{c}3(25.0) \\
3(25.0) \\
4(33.3) \\
1(8.3) \\
- \\
1(8.3) \\
-\end{array}$ & $\begin{array}{c}7(35.0) \\
- \\
8(40.0) \\
- \\
2(10.0) \\
3(15.0) \\
-\end{array}$ & $\begin{array}{c}11(61.1) \\
1(5.6) \\
4(22.3) \\
1(5.6) \\
- \\
1(5.6) \\
-\end{array}$ & $\begin{array}{c}3(27.3) \\
2(18.2) \\
5(45.5) \\
1(9.1) \\
- \\
- \\
-\end{array}$ \\
\hline $\begin{array}{l}\text { EMPLOYMENT } \\
\text { Salary/Wage Earner } \\
\text { Retired } \\
\text { Homemaker } \\
\text { Self-Employed } \\
\text { Student } \\
\text { Unemployed }\end{array}$ & $\begin{array}{c}29(34.5) \\
31(36.9) \\
10(11.9) \\
9(10.7) \\
3(3.6) \\
2(2.4)\end{array}$ & $\begin{array}{c}8(42.1) \\
5(26.3) \\
1(5.3) \\
210.5) \\
2(10.5) \\
1(5.3)\end{array}$ & $\begin{array}{c}4(28.6) \\
7(50.0) \\
2(14.3) \\
1(7.1) \\
- \\
-\end{array}$ & $\begin{array}{c}8(38.1) \\
5(23.8) \\
3(14.3) \\
4(19.0) \\
- \\
1(4.8)\end{array}$ & $\begin{array}{c}7(36.8) \\
7(36.8) \\
3(15.8) \\
2(10.5) \\
- \\
-\end{array}$ & $\begin{array}{c}2(18.2) \\
7(63.5) \\
1(9.21) \\
- \\
1(9.1) \\
-\end{array}$ \\
\hline $\begin{array}{l}\text { AGE: } \\
17-25 \\
26-35 \\
36-45 \\
46-55 \\
56-65 \\
66-75 \\
76-85 \\
86>\end{array}$ & $\begin{array}{c}6(7.2) \\
8(9.6) \\
16(19.1) \\
16(19.1) \\
14(16.7) \\
13(15.5) \\
9(10.7) \\
3(3.6)\end{array}$ & $\begin{array}{c}2(10.5) \\
- \\
6(31.7) \\
6(31.6) \\
- \\
3(15.9) \\
1(5.3) \\
1(5.3)\end{array}$ & $\begin{array}{c}- \\
4(26.6) \\
2(13.3) \\
1(6.6) \\
2(13.3) \\
5(33.3) \\
1(6.6) \\
-\end{array}$ & $\begin{array}{c}2(9.5) \\
4(19.2) \\
3(14.3) \\
4(19.2) \\
2(9.6) \\
2(9.6) \\
4(19.1) \\
-\end{array}$ & $\begin{array}{c}1(5.3) \\
- \\
2(10.6) \\
5(26.4) \\
8(42.2) \\
- \\
2(10.6) \\
1(5.3)\end{array}$ & $\begin{array}{c}1(9.1) \\
- \\
3(27.3) \\
- \\
2(18.2) \\
3(27.3) \\
1(9.1) \\
1(9.1)\end{array}$ \\
\hline $\begin{array}{l}\text { ETHNICITY: } \\
\text { White } \\
\text { Hispanic } \\
\text { Native American } \\
\text { Other }\end{array}$ & $\begin{aligned} 70 & (83.3) \\
1 & (1.2) \\
11 & (13.1) \\
2 & (2.4)\end{aligned}$ & $\begin{array}{c}15(83.3) \\
- \\
2(11.1) \\
1(5.6)\end{array}$ & $\begin{array}{c}8(53.3) \\
- \\
7(46.7) \\
-\end{array}$ & $\begin{array}{c}18(85.7) \\
1(4.8) \\
2(9.5) \\
-\end{array}$ & $\begin{array}{c}18(94.7) \\
- \\
- \\
1(5.3)\end{array}$ & $\begin{array}{c}11(100.0) \\
- \\
- \\
-\end{array}$ \\
\hline $\begin{array}{l}\text { INCOME: } \\
<\$ 10,000 \\
\$ 10-\$ 19,000 \\
\$ 20-\$ 29,000 \\
\$ 30-\$ 39,000 \\
\$ 40-\$ 49,000 \\
\$ 50-\$ 59,000 \\
\$ 60-\$ 69,000 \\
\$ 70-\$ 99,000 \\
\$ 100,000>\end{array}$ & $\begin{array}{l}7(9.6) \\
9(12.3) \\
18(24.7) \\
10(13.7) \\
13(17.8) \\
7(9.6) \\
6(8.2) \\
2(2.7) \\
1(1.4)\end{array}$ & $\begin{array}{c}2(12.5) \\
4(25.0) \\
1(6.3) \\
2(12.5) \\
5(31.3) \\
- \\
- \\
1(6.3) \\
1(6.3)\end{array}$ & $\begin{array}{c}- \\
1(9.1) \\
4(36.4) \\
- \\
3(27.3) \\
- \\
2(18.2) \\
1(9.1) \\
-\end{array}$ & $\begin{array}{c}1(5.3) \\
3(15.8) \\
4(21.1) \\
4(21.1) \\
3(15.8) \\
3(15.8) \\
1(5.3) \\
- \\
-\end{array}$ & $\begin{array}{c}2(11.8) \\
1(5.9) \\
4(23.5) \\
2(11.8) \\
2(11.8) \\
4(23.5) \\
2(11.8) \\
- \\
-\end{array}$ & $\begin{array}{c}2(20.0) \\
- \\
5(50.0) \\
2(20.0) \\
- \\
- \\
1(10.0) \\
- \\
-\end{array}$ \\
\hline $\begin{array}{l}\text { EDUCATION: } \\
\text { < High school } \\
\text { High school } \\
\text { Some college } \\
\text { Bachelors } \\
\text { Graduate }\end{array}$ & $\begin{array}{c}4(4.7) \\
21(24.7) \\
31(36.5) \\
18(21.2) \\
11(12.9)\end{array}$ & $\begin{array}{c}2(10.5) \\
3(15.8) \\
10(52.6) \\
2(10.5) \\
2(10.5)\end{array}$ & $\begin{array}{c}- \\
6(40.0) \\
7(46.7) \\
1(6.7) \\
1(6.7)\end{array}$ & $\begin{array}{c}1(4.8) \\
7(33.3) \\
4(19.0) \\
7(33.3) \\
2(9.5)\end{array}$ & $\begin{array}{c}1(5.3) \\
3(15.8) \\
5(26.3) \\
6(31.6) \\
4(21.1)\end{array}$ & $\begin{array}{c}- \\
2(18.2) \\
5(45.5) \\
2(18.2) \\
2(18.2)\end{array}$ \\
\hline
\end{tabular}




\begin{tabular}{|c|c|c|}
\hline $\begin{array}{c}\text { Demographic } \\
\text { Variable }\end{array}$ & $\begin{array}{c}\text { Telephone "Re-contact" Sample } \\
\text { (Of Camera Non-Respondents) } \\
\qquad \begin{array}{c}n=95 \\
n \quad(\%)\end{array}\end{array}$ & $\begin{array}{l}\text { Follow-up Survey Sample } \\
\text { (Of Camera Respondents) } \\
\qquad \begin{array}{c}n=87 \\
n \quad(\%)\end{array}\end{array}$ \\
\hline $\begin{array}{l}\text { GENDER: } \\
\text { Male } \\
\text { Female }\end{array}$ & $\begin{array}{l}37(38.9) \\
58(61.1)\end{array}$ & $\begin{array}{l}35(42.2) \\
48(57.8)\end{array}$ \\
\hline $\begin{array}{l}\text { OCCUPATION: } \\
\text { Managerial/Professional } \\
\text { Technical/Sale/Administration } \\
\text { Service } \\
\text { Farm/Forest/Fish } \\
\text { Precision/Craft/Repair } \\
\text { Operator/Laborer } \\
\text { Student } \\
\end{array}$ & $\begin{array}{c}25(26.3) \\
19(20.0) \\
31(32.6) \\
4(4.2) \\
3(3.2) \\
7(7.5) \\
6(6.3)\end{array}$ & $\begin{array}{c}29(36.7) \\
10(12.7) \\
25(31.7) \\
3(3.8) \\
2(2.5) \\
8(10.2) \\
2(2.5)\end{array}$ \\
\hline 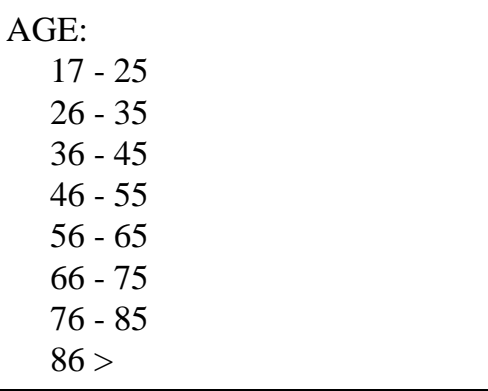 & $\begin{array}{c}14(15.0) \\
19(20.2) \\
28(29.7) \\
16(17.1) \\
11(11.7) \\
6(6.5) \\
1(1.1) \\
-\end{array}$ & $\begin{array}{c}6(7.2) \\
8(9.6) \\
16(19.1) \\
16(19.1) \\
14(16.7) \\
13(15.5) \\
9(10.7) \\
3(3.6)\end{array}$ \\
\hline $\begin{array}{l}\text { ETHNICITY: } \\
\text { White } \\
\text { Hispanic } \\
\text { Native American } \\
\text { Other }\end{array}$ & $\begin{array}{c}91(95.8) \\
3(3.2) \\
- \\
1(1.1)\end{array}$ & $\begin{aligned} 70 & (83.3) \\
1 & (1.2) \\
11 & (13.1) \\
2 & (2.4)\end{aligned}$ \\
\hline $\begin{array}{l}\text { INCOME: } \\
\quad<\$ 10,000 \\
\quad \$ 10-\$ 19,000 \\
\$ 20-\$ 29,000 \\
\$ 30-\$ 39,000 \\
\$ 40-\$ 49,000 \\
\$ 50-\$ 59,000 \\
\$ 60-\$ 69,000 \\
\$ 70-\$ 99,000 \\
\$ 100,000>\end{array}$ & $\begin{array}{c}6(6.5) \\
12(13.0) \\
8(8.7) \\
18(19.6) \\
17(18.5) \\
12(13.0) \\
5(5.4) \\
12(13.0) \\
2(2.2)\end{array}$ & $\begin{array}{l}7(9.6) \\
9(12.3) \\
18(24.7) \\
10(13.7) \\
13(17.8) \\
7(9.6) \\
6(8.2) \\
2(2.7) \\
1(1.4)\end{array}$ \\
\hline $\begin{array}{l}\text { EDUCATION: } \\
\text { < High school } \\
\text { High school } \\
\text { Some college } \\
\text { Bachelors Degree } \\
\text { Graduate School }\end{array}$ & $\begin{array}{c}3(3.2) \\
18(18.9) \\
58(61.1) \\
12(12.6) \\
4(4.2)\end{array}$ & $\begin{aligned} 4 & (4.7) \\
21 & (24.7) \\
31 & (36.5) \\
18 & (21.2) \\
11 & (12.9)\end{aligned}$ \\
\hline
\end{tabular}

